\title{
RESPOSTA À APLICAÇÃO DE URÉIA E CLORETO DE POTÁSSIO EM DOIS GENÓTIPOS DE SOJA, INOCULADOS COM

\author{
Bradyrhizobium japonicum, CULTIVADOS NO INVERNO
}

\author{
MARIA DO CARMO DE SALVO SOARES NOVO \\ Engenheira Agrônoma
}

Orientador: Prof. Dr. ÁLVARO AUGUSTO TEIXEIRA VARGAS

Dissertação apresentada à Escola Superior de Agricultura "Luiz de Queiróz", da Universidade de São Paulo, para obtenção do título de Mestre em Agronomia, Área de Concentração: Solos e Nutriçäo de Plantas

PIRACICABA

Estado de São Paulo - Brasil Junho - 1995 


\section{RESPOSTA À APLICAÇÃo DE URÉIA E CLORETO DE POTÁSSIO} EM DOIS GENÓTIPOS DE SOJA, INOCULADOS COM Bradyrhizobium japonicum, CULTIVADOS NO INVERNO

MARIA DO CARMO DE SALVO SOARES NOVO

Aprovada em 29.08.1995

Comissão Julgadora:

Prof. Dr. Álvaro Augusto Teixeira Vargas

Prof. Dr. Márcio Rodrigues Lambais

Dr. Roberto Tetsuo Tanaka
ESALQ/USP ESALQ/USP IACISAASP

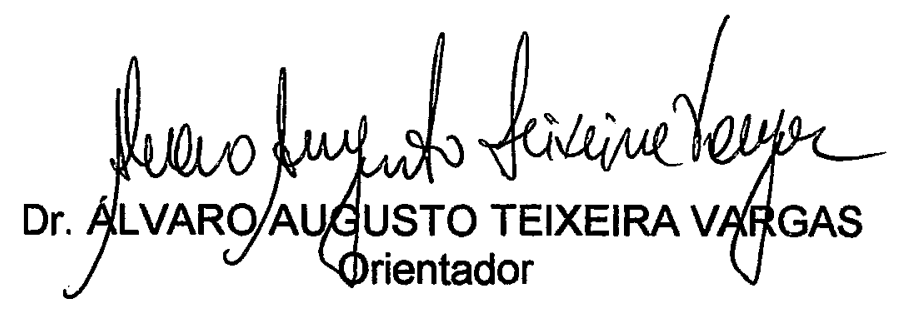


CATALOEACAO NA FUELICAGAO

OIVISAO DE RIBLJOTECA E DOCUMENTACAO - CAMFUS "LUIZ DE QUEJRO?"/USF

Novo. Maria do Carmo de Salvo Soares

Nesposta à aulicaca de uréia e cloreto de votássio er dois enótipos de 50ja. inoculados con Braúvhizobiu jasonicun, zultivados no inverno.. Piracicaba, 1995.

113p. ilus.

Dis5. (Hestre\} - ESALQ

Diblioụrafia.

1. Soja de inverno - Adubaczo nstrọenada 2. So ia de inverno - Adutazca potassica 3. Soja de inverno - Nutrica 1. Escola Suberior de Aaricultura Luiz de Queiroz, Piracicaba

$200 \quad 633.34$ 
Aos meus pais, Ary e Wilma

pelos esforços dedicados à minha educação, OEEREÇO

Para José, Carolina e Bruno, com amor, DEDICO 


\section{AGRADECIMENTOS}

Ao Prof. Dr. Álvaro Augusto Teixeira Vargas, pela orientação no desenvolvimento do presente trabalho.

Aos Professores do Departamento de Solos da ESALQ/USP pelos ensinamentos.

Aos Pesquisadores Científicos Hipólito Assunção Antonio Mascarenhas e Roberto Tetsuo Tanaka pela colaboração no desenvolvimento do experimento.

A Pesquisadora Cientifica Violeta Nagai pelas sugestóes na análise estatística.

A Pesquisadora Científica sandra sevá Nogueira pelo constante apoio, amizade e sugestões apresentadas.

As ex-funcionárias da Seção de Microbiologia do solo do Instituto Agronômico Maria Madalena Caetano e Sonia José Lopes silva e à funcionária Maria Leonilde Machado Souza pelo auxílio na contagem e pesagem de nódulos. 
Aos Pesquisadores Científicos José Carlos Vila Nova Alves Pereira, Nelson Bortoleto e Paulo Boller Gallo pela condução dos experimentos nas Estaçóes Experimentais de Ribeiråo Preto, Votuporanga e Mococa, respectivamente.

Ao Engenheiro Agronômo Claúdio Fernando De Gáspari pelo auxilio nas amostragens e análises de plantas.

Ao Pesquisador Científico José Polese Soares Novo pela colaboração na ediçăo do texto.

Ao Instituto Agronomico pelas condiçơes oferecidas.

As demais pessoas que direta ou indiretamente colaboraram na realização deste trabalho.

Ao CNPq pela concessão de Bolsa de Estudo durante parte do curso. 


\section{SUMÁRIO}

página

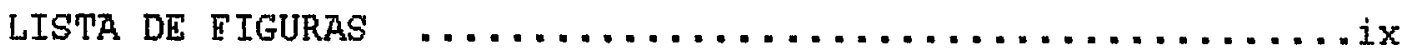

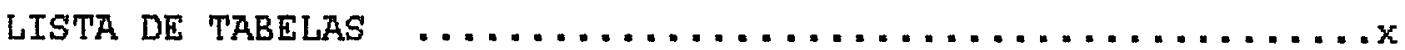

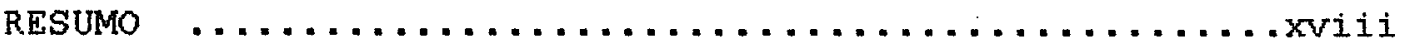

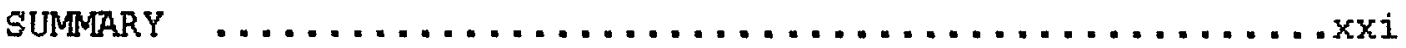

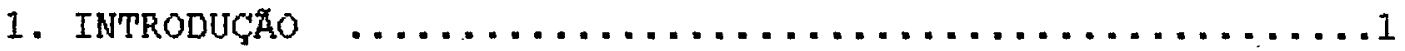

2. REVISAO DE LITERATURA $\ldots \ldots \ldots \ldots \ldots \ldots \ldots \ldots \ldots \ldots \ldots \ldots$

2.1. Efeito de Cultivar ....................

2.2. Efeito do Nitrogênio $\ldots \ldots \ldots \ldots \ldots \ldots \ldots \ldots \ldots . \ldots \ldots$

2.3. Efeito do Potássio ........................

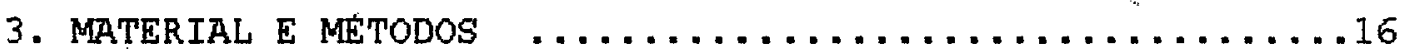

3.1. Local de Conduçăo do Experimento e Características

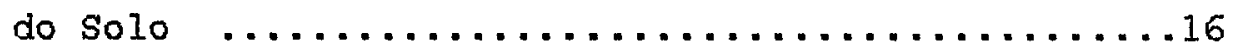

3.2. Preparo do solo $\ldots \ldots \ldots \ldots \ldots \ldots \ldots \ldots \ldots$

3.3. Tratamentos e Características das Parcelas ......17

3.4. Tratos Culturais ...................... 18

3.5. Amostragens das Plantas e Determinaçóes...........20

3.6. Métodos Analiticos .......................... 20

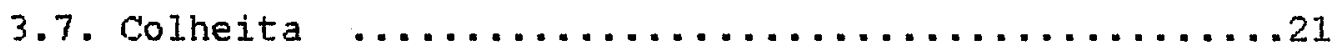

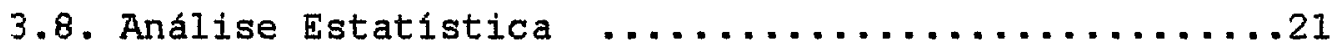

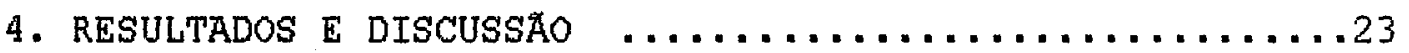

4.1. Efeito de Cultivar $\ldots \ldots \ldots \ldots \ldots \ldots \ldots \ldots \ldots$ 


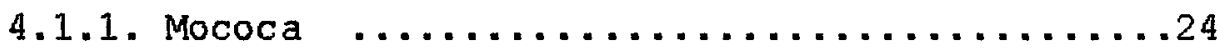

4.1.1.1. Cultivar Dentro de Doses de Nitro-

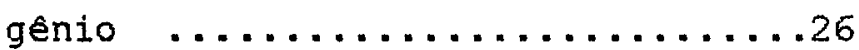

4.1.1.2. Cultivar Dentro de Doses de Potássio $\ldots \ldots \ldots \ldots \ldots \ldots \ldots \ldots \ldots \ldots . \ldots \ldots$

4.1.2. Ribeirăo Preto $\ldots \ldots \ldots \ldots \ldots \ldots \ldots \ldots . \ldots \ldots 2$

4.1.2.1. Cultivar Dentro de Doses de Nitro-

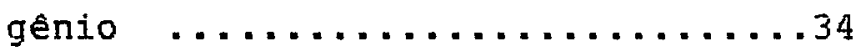

4.1.2.2. Cultivar Dentro de Doses de Potás-

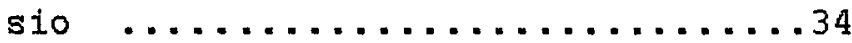

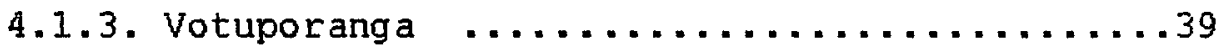

4.1.3.1. Cultivar Dentro de Doses de Nitro-

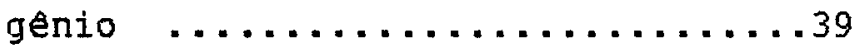

4.1.3.2. Cultivar Dentro de Doses de Potássio $\ldots \ldots \ldots \ldots \ldots \ldots \ldots \ldots \ldots . \ldots \ldots$

4.2. Efeito de Doses de Nitrogênio $\ldots \ldots \ldots \ldots \ldots \ldots 46$ 4.2 .1 . Mococa $\ldots \ldots \ldots \ldots \ldots \ldots \ldots \ldots \ldots \ldots . . . .46$

4.2.1.1. Doses de Nitrogenio Dentro de Cultivar $\ldots \ldots \ldots \ldots \ldots \ldots \ldots \ldots \ldots+\ldots \ldots$

4.2.1.2. Doses de Nitrogênio Dentro de Doses de Potássio...............53

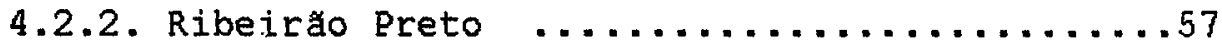

4.2.2.1. Doses de Nitrogenio Dentro de Cultivar $\ldots \ldots \ldots \ldots \ldots \ldots \ldots \ldots \ldots$

4.2.2.2. Doses de Nitrogênio Dentro de Doses de Potássio $\ldots \ldots \ldots \ldots \ldots \ldots 1$ 
4.2.3.1. Doses de Nitrogênio Dentro de Cultivar $\ldots \ldots \ldots \ldots \ldots \ldots \ldots \ldots \ldots \ldots$

4.2.3.2. Doses de Nitrogénio Dentro de Doses de Potássio .............70

4.3. Efeito de Doses de Potássio ................70 4.3.1. Mococa $\ldots \ldots \ldots \ldots \ldots \ldots \ldots \ldots \ldots . . . \ldots 73$

4.3.1.1. Doses de Potássio Dentro de Cultivar.. $\ldots \ldots \ldots \ldots \ldots \ldots \ldots \ldots \ldots+\ldots \ldots$

4.3.1.2. Doses de Potássio Dentro de Doses de Nitrogênio $\ldots \ldots \ldots \ldots \ldots \ldots .78$

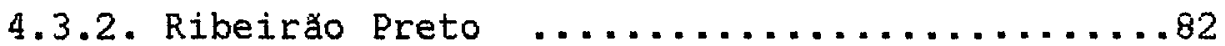

4.3.2.1. Doses de Potássio Dentro de Culti-

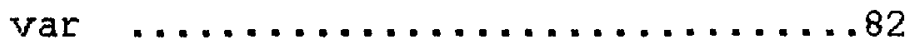

4.3.2.2. Doses de Potássio Dentro de Doses de Nitrogenio $\ldots \ldots \ldots \ldots \ldots \ldots . \ldots . \ldots 6$

4.3.3. Votuporanga $\ldots \ldots \ldots \ldots \ldots \ldots \ldots . . . . . . .90$

4.3.3.1. Doses de Potássio Dentro de Cultivar $\ldots \ldots \ldots \ldots \ldots \ldots \ldots \ldots \ldots+\ldots \ldots$

4.3.3.2. Doses de Potássio Dentro de Doses de Nitrogenio $\ldots \ldots \ldots \ldots . . . . .93$

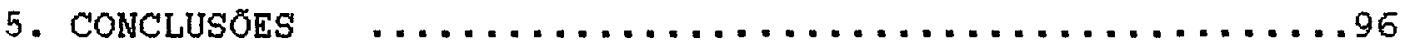

6. REEERENCIAS BIBLIOGRAFICAS $\ldots \ldots \ldots \ldots \ldots \ldots \ldots \ldots$ 
LISTA DE FIGURAS

página

Figura 1. Respostas dos cultivares de soja IAC-8 e IAC-14 às doses de potássio quanto a matéria seca (1A) e número de nódulos (1B) e à \& de $\mathbf{N}$ da parte aerea (IC) em Votuporanga. Médias..........................44

Figura 2. Efeito de doses de nitrogenio sobre os teores de $\mathbf{N}$ da parte aérea (2A) e dos grăos (2B) e sobre a produtividade de grăos (2C) em Mococa (MC), Ribeirăo Preto (RP) e votuporanga (VT) .............48

Figura 3. Efeito de doses de potássio dentro de cultivares sobre a 8 de $\mathbf{N}$ da parte aérea (3A) e sobre a materia seca (3B) e número de nódulos (3C) em Votuporanga...........92

Figura 4. Efeito de doses de potássio dentro de doses de nitrogenio sobre a materia seca (4A) e o número de nódulos (4B) em Votuporanga.......................... 94 
LISTA DE TABELAS

página

Tabela 1. Resultado das análises químicas da camada superficial do solo $(0-20 \mathrm{~cm})$ das áreas experimentais....................

Tabela 2. Datas da semeadura, germinaçao, florescimento e colheita dos cultivares de soja IAC-8 e IAC-14 em Mococa, Ribeirao Preto e Votuporanga. ..................... . 19

Tabela 3. Matéria seca $\theta$ teores de $\mathbf{N}$ e de $\mathbf{K}$ da parte aérea, matéria seca e número de nódulos, reduçấo do acetileno, teor de $\mathbf{N}$ e produtividade de grăos dos cultivares de soja IAC-8 e IAC-14 em Mococa. Médias.........25

Tabela 4. Materia seca e teores de $\mathbf{N}$ e de $\mathbf{K}$ da parte aérea, teor de $\mathbf{N}$ e produtividade de grăos dos cultivares de soja IAC-8 e IAC-14 dentro de doses de nitrogenio em Mococa. Me-

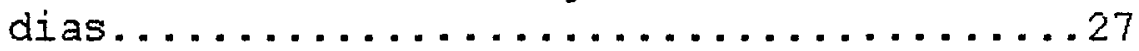

Tabela 5. Matéria seca e número de nódulos e reduçăo do acetileno dos cultivares de soja IAC-8 e IAC-14 dentro de doses de nitrogénio em Mococa. Médias.....................28

Tabela 6. Matéria seca e teores de $\mathbf{N}$ e de $\mathbf{K}$ da parte aérea, teor de $\mathbf{N}$ e produtividade de gráos dos cultivares de soja IAC-8 e IAC-14 dentro de doses de potássio em Mococa. Médias. 30

Tabela 7. Matéria seca e número de nódulos e reduçăo do acetileno dos cultivares de soja IAC-8 
- IAC-14 dentro de doses de potássio em Mococa. Médias.......................31

Tabela 8. Materia seca e teores de $\mathbf{N}$ e de $\mathbf{K}$ da parte aerea, materia seca e número de nódulos, reduçåo do acetileno, teor de $\mathbf{N}$ e produtividade de graos dos cultivares de soja IAC-8 e IAC-14 em Ribeirão Preto. Médias...33

Tabela 9. Materia seca e teores de $\mathbf{N}$ e de $\mathbf{K}$ da parte aerea, teor de $\mathbf{N}$ e produtividade de grăos dos cultivares de soja IAC-8 e IAC-14 dentro de doses de nitrogenio em Ribeirão Preto.Medias.......................35

Tabela 10. Matoria seca e número de nódulos, redução do acetileno dos cultivares de soja IAC-8 e IAC-14 dentro de doses de nitrogenio em Ribeiråo Preto. Médias...............36

Tabela 11. Matéria seca e teores de $\mathbf{N}$ e de $\mathbf{K}$ da parte aerea, teor de $\mathbf{N}$ e produtividade de graos dos cultivares IAC-8 e IAC- 14 dentro de doses de potássio em Ribeirão preto. Medias................................

Tabela 12. Matéria seca e número de nódulos e reduçăo do acetileno dos cultivares de soja IAC-8 e IAC-I4 dentro de doses de potássio em beirgo preto. Medias................38

Tabela 13. Materia seca $\theta$ teores entre de $\mathbf{N}$ e de $\mathbf{K}$ da parte aérea, matéria seca e número de nódulos, redução do acetileno, teor de $\mathbf{N} e$ produtividade de gráos dos cultivares de soja IAC-8 e IAC-14 em Votuporanga. Médias. 40

Tabela 14. Matéria seca e teores de $\mathbf{N}$ e de $\mathbf{K}$ da parte aérea, teor de $\mathbf{N}$ e produtividade de gräos dos cultivares de soja IAC-8 e IAC-14 den tro de doses de nitrogenio em Votuporanga. Médias......................41

Tabela 15. Materia seca e número de nódulos e redução do acetileno dos cultivares de soja IAC-8 e IAC-14 dentro de doses de nitrogenio em Votuporanga. Médias...............42 
Tabela 16. Médias das variáveis, significancia das análises de regressa polinomial linear e quadrática, seus coeficientes de determinaçăo e ponto de inflexão com a referente produção quanto ao efeito de doses de nitrogenio quanto as materias secas da parte aérea e de nódulos, número de nódulos, \& de $\mathbf{N}$ da parte aérea e dos grấos, \& de $\mathbf{K}$ da parte aérea, reduçăo do acetileno e produtividade de grãos em Mococa.... . . 47

Tabela 17. Médias das variáveis, significancia das analises de regressao polinomial linear e quadratica, seus coeficientes de determinação $\theta$ ponto de inflexão com a referente produção quanto ao efeito de doses de nitrogenio dentro de cultivares na materia seca da parte aérea, 8 de $\mathbf{N}$ da parte aérea e dos grãos, 8 de $\mathbf{K}$ da parte aérea e produtividade de grăos em Mococa...........51

Tabela 18. Médias das variáveis, significancia das análises de regressão polinomial linear e quadrática, seus coeficientes de determinaçăo e o ponto de inflexăo com a referente produção quanto ao efeito de doses de nitrogenio dentro de cultivares na matéria seca e número de nódulos e quanto a reduça do acetileno em Mococa............52

Tabela 19. Médias das variáveis, significancia das análises de regressão polinomial linear e quadrática, seus coeficientes de determinaça e o ponto de inflexáo com a referente produção quanto ao efeito de doses de nitrogenio dentro de doses de potássio na materia seca da parte aerea, 8 de $\mathbf{N}$ da parte aerea e dos gräos, 8 de $\mathbf{K}$ da parte aérea e produtividade de grãos...........54

Tabela 20. Medias das variáveis, significancia das análises de regressa polinomial linear e quadrática, seus coeficientes de determinaçăo e o ponto de inflexăo com a referente produçăo quanto ao efeito de doses de nitrogenio dentro de doses de potássio na 
matéria seca e número de nódulos e quanto a redução do acetileno em Mococa........55

Tabela 21. Médias das variáveis, significancia das analises de regressão polinomial linear e quadrática, seus coeficientes de determinação e o ponto de inflexåo com a referente produção quanto ao efeito de doses de nitrogenio dentro de doses de potássio nas materias secas da parte aerea e de nodu105, número de nódulos, o de $\mathbf{N}$ da parte aérea e dos graos, 8 de $\mathbf{K}$ da parte aerea, redução do acetileno e produtividade de graos em Ribeirao preto.............58

Tabela 22. Médias das variáveis, significancia das análises de regressao polinomial linear e quadratica, seus coeficientes de determinação e o ponto de inflexão com a referente produção quanto ao efeito de doses de nitrogenio dentro de cultivares na materia seca da parte aérea, 8 de $\mathbf{N}$ da parte área $\theta$ dos gráos, o de $\mathbf{k}$ da parte aerea e produtividade de grăos em Ribeirăo preto.....60

Tabela 23. Médias das variáveis, significancia das análises de regressão polinomial linear e quadrática, seus coeficientes de determinação e ponto de inflexao com a referente produção quanto ao efeito de doses de nitrogenio dentro de cultivares na materia seca e número de nódulos e reduçåo do acetileno em Ribeirăo Preto.............62

Tabela 24. Médias das variáveis, significância das análises de regressao polinomial linear e quadrática, seus coeficientes de determinaçăo e o ponto de inflexao com a referente produção quanto ao efeito de doses de doses de nitrogenio dentro de doses de potássio na materia seca da parte aérea, 8 de $\mathbf{N}$ da parte aérea e dos grãos, 8 de $\mathbf{K}$ da parte aerea e produtividade de gráos em Ribeiråo Preto...................63

Tabela 25. Medias das variáveis, significancia das análises de regressa polinomial linear e 
quadrática, seus coeficientes de determinaçăo e o ponto de inflexăo com a referente produção quanto ao efeito de doses de nitrogenio dentro de doses de potássio na materia seca e número de nódulos e quanto a reduçåo do acetileno em Ribeirão preto...64

Tabela 26. Médias das variáais, significancia das análises de regressa polinomial linear e quadrática, seus coeficientes de determinaçăo e o ponto de inflexăo com a referente produçåo quanto ao efeito de doses de nitrogenio nas materias secas da parte aérea e de nódulos, número de nódulos, of de $\mathbf{N}$ da parte aérea e dos grăos, ơ de $\mathbf{K}$ da parte aérea, redução do acetileno e produtividade de gráos em votuporanga.......66

Tabela 27. Médias das variáveis, significância das análises de regressão polinomial linear e quadrática, seus coeficientes de determinaçăo e ponto de inflexao com a referente produção quanto ao efeito de doses de nitrogenio na materia seca da parte aérea, \& de $\mathbf{N}$ da parte aérea e dos graos, $\frac{o}{8}$ de $\mathbf{K}$ da parte aerea e produtividade de graos em votuporanga...................68

Tabela 28. Medias das variáveis, significancia das analises de regressa polinomiais linear e quadrática, seus coeficientes de determinação e o ponto de inflexăo com a referente produça quanto ao efeito de doses de nitrogenio dentro de cultivares na matéria seca e número de nódulos e quanto a reduçåo do acetileno em votuporanga.........69

Tabela 29. Médias das variáveis, significancia das análises de regressao polinomial linear e quadratica, seus coeficientes de determinação e ponto de inflexão com a referente produção quanto ao efeito de doses de nitrogenio dentro de doses de potássio na matéria seca da parte aerea, o de $\mathbf{N} d a$ parte aerea e dos graos, 8 de $K$ da parte aerea e produtividade de grăos em Votuporanga......................... 71 
Tabela 30. Médias das variáveis, significancia das análises de regressão polinomial linear e quadrática, seus coeficientes de determinaçăo e o ponto de inflexão com a referente produção quanto ao efeito de doses de doses de nitrogenio dentro de doses de potássio na matéria seca e número de nódulos e quanto a redução do acetileno em Votuporanga.......................... 72

Tabela 31. Médias das variáveis, significancia das análises de regressa polinomial linear e quadrática, seus coeficientes de determinação e ponto de inflexăo com a referente produção quanto ao efeito de doses de potássio nas matérias secas da parte aérea e de nódulos, número de nódulos, \& de $\mathbf{N}$ da parte aerea e dos gráos, 8 de $\mathbf{k}$ da parte aérea, redução do acetileno e produtividade de grăos em Mococa ..........

Tabela 32. Médias das variáveis, significancia das análises de regressåo polinomial linear e quadrática, seus coeficientes de determinaçăo e ponto de inflexao com a referente produção quanto ao efeito de doses de potássio dentro de cultivares na materia seca da parte aérea, of de $\mathbf{N}$ da parte aerea e dos graos, 8 de $\mathbf{K}$ da parte aerea e produtividade de grãos em Mococa.........76

Tabela 33. Medias das variáveis, significancia das análises de regressao polinomial linear e quadrática, seus coeficientes de determinação e o ponto de inflexão com a referente produção quanto ao efeito de doses de potássio dentro de cultivares na matéria seca e número de nódulos e quanto a reduça do acetileno em Mococa.............77

Tabela 34. Medias das variáveis, significancia das análises de regressa polinomial linear e quadratica, seus coeficientes de determinaçăo e o ponto de inflexáo com a referente produção quanto ao efeito de doses de potássio dentro de doses de nitrogenio na materia seca da parte aerea, o de $\mathbf{N}$ da 
parte aérea e dos grăos : de $\mathbf{K}$ da parte aérea e produtividade de gráos em Mococa...79

Tabela 35. Médias das variáveis, significancia das analises de regressa polinomial linear e quadrática, seus coeficientes de determinação e o ponto de inflexão com a referente produção quanto ao efeito de doses de doses de potássio dentro de doses de nitrogenio na matéria seca e número de nódulos e quanto a redução do acetileno em Mococa.............................

Tabela 36. Médias das variáveis, significancia das análises de regressåo polinomial linear e quadrática, seus coeficientes de determinação e o ponto de inflexăo com a referente produça quanto ao efeito de doses de potássio nas matérias secas da parte aérea e de nódulos, número de nódulos, a de $\mathbf{N}$ da parte aérea e dos grăos, $\frac{8}{8}$ de $\mathbf{k}$ da parte aerea, redução do acetileno e produtividade de grăos em Ribeiråo preto.......83

Tabela 37. Medias das variáveis, significancia das analises de regressa polinomial linear e quadrática, seus coeficientes de determinação e o ponto de inflexão com a referente produçao quanto ao efeito de doses de potassio dentro de cultivares na materia seca da parte aérea, \& de $\mathbf{N}$ da parte aérea e dos grãos, of de $\mathbf{K}$ da parte aérea e produtividade de grăos em Ribeiråo preto.....84

Tabela 38. Médias das variáveis, significancia das análises de regressa polinomiais linear e quadrática, seus coeficientes de determinaçăo e ponto de inflexão com a referente produção quanto ao efeito de doses de potássio dentro de cultivares na matéria seca e número de nódulos e quanto a redução do acetileno em Ribeirăo Preto......85

Tabela 39. Médias das variáveis, significancia das análises de regressao polinomial linear e quadrática, seus coeficientes de determinação o ponto de inflexão com a referen- 
te produção quanto ao efeito de doses de potássio dentro de doses de nitrogenio quanto a materia seca da parte aérea, 8 de $\mathbf{N}$ da parte aérea e dos grãos, o de $\mathbf{K}$ da parte aerea e produtividade de grăos em Ribeirăo Preto..................87

Tabela 40. Medias das variáveis, significancia das analises de regressao polinomial linear e quadrática, seus coeficientes de determinação e o ponto de inflexão com a referente produção quanto ao efeito de doses de potássio dentro de doses de nitrogenio na materia seca e número de nódulos e quanto a redução do acetileno em Ribeirão preto...88

Tabela 41. Medias das variáveis, significancia das análises de regressa polinomial linear e quadrática, seus coeficientes de determinação e o ponto de inflexăo com a referente produção quanto ao efeito de doses de potássio na matérias secas da parte aerea e de nódulos, número de nódulos, o de $\mathbf{N}$ da parte aerea e dos graos, o de $\mathbf{K}$ da parte aerea, redução do acetileno e produtividade de gratos em votuporanga..........91 


\title{
RESPOSTA A APLICAÇÃO DE URÉIA E CLORETO DE POTÁSSIO EM DOIS GENÓTIPOS DE SOJA, INOCULADOS COM Bradyrhizobium japonicum, CULTIVADOS NO INVERNO
}

\author{
Autora: MARIA DO CARMO DE SALVO SOARES NOVO \\ Orientador: DR. ALVARO AUGUSTO TEIXEIRA VARGAS
}

RESUMO

Com o objetivo de estudar a resposta de dois genótipos de soja cultivados no inverno à aplicação de doses de nitrogênio e de potássio foi instalado um experimento nas Estações Experimentais de Mococa, Ribeiråo Preto e Votuporanga.

o delineamento experimental empregado foi o de blocos ao acaso, com esquema fatorial, sendo utilizados 3 doses de nitrogenio $(0,50$ e $100 \mathrm{~kg} / \mathrm{ha}$ de $\mathbf{N}), 3$ doses de potássio $\left(0,30\right.$ e $60 \mathrm{~kg} / \mathrm{ha}$ de $\left.\mathrm{K}_{2} \mathrm{O}\right)$ e dois cultivares de soja (IAC-8 e IAC-14). Como fontes de nitrogenio e de potássio foram usadas, respectivamente, uréia e cloreto de potássio. As parcelas eram compostas de 4 linhas de $6 \mathrm{~m}$ de comprimento espaçadas em $0,60 \mathrm{~m}$. Pouco antes da semeadura, as sementes foram inoculadas com inoculante turfoso sendo 
empregadas as estirpes de Bradyrhizobium japonicum SEMIA 587 + SEMIA 5019 .

No estádio de florescimento pleno, retiraram-se 3 plantas por parcela, sendo as raízes destinadas à avaliação da nodulaçåo e à determinação da nitrogenase. Foram determinados também a matéria seca da parte aérea e os teores de $\mathbf{N}$ e de $\mathbf{K}$ da parte aérea. No final do ciclo, determinou-se a produtividade e o teor de $\mathbf{N}$ do grao.

A inoculação das sementes com as estirpes recomendadas nåo foi capaz de suprir adequadamente a soja de maneira a se obter rendimentos similares aquelas obtidas com a adição de nitrogenio. A adição de nitrogenio prejudicou a nodulação e a fixação simbiótica do nitrogênio. Em Votuporanga, a nodulação e a fixação do nitrogênio do cultivar IAC-8 mostrou ser menos sensivel à adição de nitrogênio. Tanto o nitrogênio quanto o potássio adicionados nå afetaram significativamente a maior parte dos componentes da produção nos dois cultivares mostrando que existe um ponto de equilíbrio entre as diversas funções dos componentes da produtividade.

Houve resposta para a produção de grãos pela adição de nitrogenio para ambos os cultivares. Os cultivares foram semelhantes quanto a produtividade, com exceçåo em Mococa, onde IAC-14 mostrou ser mais produtivo.

o fornecimento de potássio não afetou a produção de grãos em nenhuma das condições do experimento, fato 
talvez explicado pelo já existente alto teor do nutriente dos solos originais. 


\section{RESPONSES TO UREA AND POTASSIUM CHLORIDE APPLICATIONS BY TWO SOYBEAN GENOTYPES INOCULATED WITH Bradyrhizobium japonicum DURING THE WINTER SEASON}

Author: MARIA DO CARMO DE SALVO SOARES NOVO Adviser: DR. ALVARO AUGUSTO TEIXEIRA VARGAS

SUMMARY

To study the response of two soybean genotypes (IAC-8 and IAC-14) to winter planting, with the use of inoculant, and the application of increasing doses of nitrogen and potassium, an experiment was installed at three Experimental stations - Mococa, Ribeiråo Preto and Votuporanga.

The experimental design was a factorial with three doses of nitrogen $(0,50$ and $100 \mathrm{~kg} / \mathrm{ha}$ of $\mathbf{N}$ as urea) and three doses of potassium $\left(0,30\right.$ and $60 \mathrm{~kg} / \mathrm{ha}$ of $\mathrm{K}_{2} \mathrm{O}$ as potassium chloride). The plots consisted of four lines of 6 meters and the spacing between the lines was $0.60 \mathrm{~m}$. Just before planting soybean, seeds were inoculated with Bradyrhizobium japonicum strains SEMIA 587 + SEMIA 5019. At flowering (full bloom) three plants per plot were harvest and the roots were used to evaluate nodulation and determine nitrogenase activity. Shoots were dried and your 
determine nitrogenase activity. Shoots were dried and your $\mathbf{N}$ and $\mathbf{K}$ were determined. At the end of cycle, the grain yield and nitrogen in the grain were evaluated.

Inoculation with the recommended strains were not capable to supply nitrogen adequately as compared to nitrogen fertilization. Nitrogen fertilization had a negative effect on nodulation and the symbiotic nitrogen fixation.

At Votuporanga, nitrogen fertilization showed less effect on genotype IAC-8 nodulation and nitrogen fixation. At the other two sites the nodulation was reduced.

Both nitrogen and potassium did not affect significantly the yield of the genotypes regarding dry matter of the above ground parts. The concentration of the nutrients showed that there is an equilibrium point between the different functions of yield components production.

There was a response for the grain yield with nitrogen application to the two genotype. The yield of the two genotypes were similar at Ribeirao preto and Votuporanga where the cultivar IAC-8 showed to be more productive.

The application of potassium did not effect the grain yield, possibly because of high potassium concentration in the soil. 


\section{INTRODUÇÃo}

A soja é tradicionalmente cultivada no veråo devido a sensibilidade da maioria dos cultivares comerciais ao fotoperiodo, obtendo-se altos rendimentos de grạos (MIYASAKA et al., 1970).

A possibilidade de cultivar soja com o objetivo de produzir sementes em regióes de inverno pouco rigoroso usando-se irrigaçăo, levou os agricultores a intensificarem a sua exploração, diminuindo os custos da tecnologia aplicada e amortizando o preço da terra. A produção da estação de inverno é menor que a do verao mas, como se destina à semente e, seu preço é superior em de $40{ }^{\circ}$ ao da soja industrial, esse cultivo pode-se tornar económico. Alem disso, os fatores climáticos dessa epoca são limitantes às pragas e doenças, reduzindo o investimento com defensivos agrícolas.

A cultura da soja exigente em nitrogênio principalmente nos estádios finais de seu desenvolvimento. vários trabalhos mostraram que a simbiose rizóbioleguminosa, nas condiçoes de verão, é eficiente e pode maximizar a produção desde que nenhum fator ambiental ou 
prática cultural limite a nodulação $\theta$ a fixaçåo simbiótica (THOMAS \& RAPER JR, 1976). Para a soja cultivada no inverno, pouco se conhece sobre a eficiencia das estirpes de rizóbio. TANAKA \& MASCARENHAS (1992) observaram que nessas condições, a simbiose não era capaz de suprir o $\mathbf{N}$ adequadamente à cultura.

Na região Mogiana do Estado de São Paulo, o cultivo de inverno tem sido feito sob pivô central com aplicação pesada de adubo nitrogenado, causando intenso crescimento vegetativo, com acamamento no cultivar IAC-8. Quando não se aplicava $\mathbf{N}$, o sistema radicular desenvolviase apenas superficialmente causando deficiencia do elemento.

Suspeita-se que a ineficiência das estirpes de rizóbio em suprir com nitrogênio à soja cultivada no inverno em quantidades suficiente para seus processos metabólicos seja devido a menor disponibilidade de fotossintetizados em decorrência da baixa temperatura. BUIS et al. (1988) observaram que com o resfriamento do ar, ocorre bloqueio da translocaçao de assimilados, reduzindo a fixação simbiótica do $\mathbf{N}$.

o potássio (K) é essencialmente importante para a simbiose e săo necessários maiores quantidades desse elemento que de qualquer outro para que ocorra acúmulo de $\mathbf{N}$ nas leguminosas. Também há resposta à adubação potássica para a produção de matéria seca e acúmulo de $\mathbf{N}$ nessa 
cultura quando cultivada no verao (MARKUS \& BATTLE, 1965; ADAMS \& SHEARD, 1966; JONES et al., 1977).

os objetivos deste experimento foram:

1) verificar se há resposta da soja IAC-8 e IAC-14 inoculada com Bradyrhizobium japonicum à aplicação de $\mathbf{N}$ mineral e potássio;

2) verificar se a nodulaçăo em condiçớs de inverno é influenciada pelas adubaçóes nitrogenada e potássica; 


\section{REVISÃO DE LITERATURA}

A pesquisa em soja tem sido favorecida pelo aumento da demanda de produtos provenientes dessa planta. 0 acúmulo de nutrientes durante o desenvolvimento vegetativo, quando a disponibilidade no solo é suficiente, é controlado pelas condições climáticas da estação de crescimento (BATAGLIA \& MASCARENHAS, 1982). Mesmo quando favoráveis, o rendimento de grãos pode ser reduzido se a disponibilidade de algum nutriente for limitante ou excessiva no solo, prejudicando a absorção de outros nutrientes e, por vezes, a fixaçåo do nitrogenio.

A determinação da necessidade de inocular e/ou de adicionar $\mathbf{N}$ ao cultivo de leguminosas é uma consideração importante quando se trata de cultivo de inverno. Frequentemente, a decisåo de usar inoculante năo é condicionada a qualquer efeito mensurável do ambiente. Geralmente, a história do cultivo, a magnitude e a eficiencia de populaçóes naturalizadas de rizóbio, a disponibilidade de $\mathbf{N}$ e de outros nutrientes do solo em relaça à necessidade da leguminosa e os fatores ambientais que interagem com 0 manejo, determinam 0 potencial de 
produção da planta e suas necessidades nutricionais.

Por isso, serão discutidos a seguir os efeitos do cultivar, do nitrogênio e do potássio na cultura da soja.

\subsection{EFEITO DE CULTIVAR}

- ambiente e a carga genetica influenciam o processo de infecção e de nodulação (SINCLAIR et aI., 1991), a resposta a fertilizantes e, consequentemente o rendimento de grãos. NANGJU (1980) verificou que há diferença na resposta de cultivares ao rizóbio quanto a nodulação, crescimento, exudação de $\mathbf{N}$-aminico e o rendimento de grăos.

PATTERSON \& LARUE (1983) verificaram que a fixação do nitrogênio em soja estava relacionada como grupo de maturaçăo sendo que, os cultivares tardios fixavam mais $\mathbf{N}$ que os precoces. Entretanto, dentro dos grupos de maturação foi observado que havia pouca variação entre cultivares quanto a atividade fixadora do $\mathbf{N}$.

Os cultivares IAC-8 e IAC-14 foram desenvolvidos por MIRANDA et al. $(1980,1988)$. IAC-8 e um cultivar de ciclo médio (130-140 dias), de crescimento determinado desenvolvido para ser semeado em outubro, ampliando o período de semeadura da soja, e próprio para ser também cultivado no cerrado. O cultivar IAC-14 é de ciclo médio, de crescimento determinado e apresenta maior resistencia ao 
acamamento que $\circ I A C-8$, além de ser menos sujeito a fatores climáticos após a maturação. Nenhum desses cultivares entretanto foi desenvolvido para ser cultivado no inverno e se obter altos rendimentos de grãos.

OUATTARA \& WEAVER (1994) relataram que o plantio fora da época normal reduz a produtividade e afeta a maioria das características agronômicas. Essa reduçăo na produtividade parece estar associada com falta de crescimento vegetativo suficiente para $\circ$ bom desenvolvimento da soja. Mudanças na temperatura exercem efeito pronunciado no crescimento na planta pois alteram a taxa de reações químicas e com isso, restringe a absorção e a translocaçào de água e minerais. Além disso, com o abaixamento da temperatura, ocorrem mudanças diferenciais nos processos de divisăo celular e elongação (BUIS et al., 1988).

\subsection{EEEITO DO NITROGENNIO}

Para se obter umá produtividade satisfatória de soja é necessário grande quantidade de $\mathbf{N}$, podendo ser utilizado pela planta o proveniente do solo, o do fertilizante ou o fixado simbioticamente.

E prática comum em áreas de cultivo de soja de verăo que esta seja mais dependente do $\mathbf{N}$ proporcionado pela fixaçăo simbiótica que do adubo pois, a aplicação deste 
insumo raramente compensa economicamente (KURTZ, 1976 ). Segundo TANAKA \& MASCARENHAS (1992), quando a inoculação é feita de acordo com as recomendaçós técnicas, pode-se obter rendimento de grãos superiores a $4 \mathrm{t} / \mathrm{ha}$.

BOONKERD et al. (1978) observaram que há resposta à inoculação somente em áreas novas ao cultivo de soja pois em solos cultivados anteriormente a populaçăo de rizóbio já estabelecida é altamente competitiva por sítios de infecção (JOHNSON \& MEANS, 1960). De acordo com HERRIDGE \& BERGENSEN (1988), quando existe no solo uma população de rizóbio infectiva com alto número de individuos, os mesmos formam uma barreira à eficiencia das estirpes do inoculante sendo que, menos de 108 dos nódulos formados săo originados do inoculante.

Em um período curto, de trés a quatro meses, grandes quantidades de $\mathbf{N}$ săo necessárias para suprir as exigencias da soja demandando alta disponibilidade desse elemento do solo e, especialmente, da fixação. Foi demonstrado por VEST et al. (1973) que a simbiose sojaBradyrhizobium japonicum fixa entre 100 e $160 \mathrm{~kg} / \mathrm{ha}$ de $\mathbf{N}$ dependendo de seu potencial de produção, da disponibilidade de $\mathbf{N}$ do solo e da interação entre o genótipo da planta hospedeira e da estirpe de rizóbio. De acordo com WEBER (1966), O N requerido para o rendimento de $2750 \mathrm{~kg} / \mathrm{ha}$ de grãos é de, aproximadamente, $215 \mathrm{~kg} / \mathrm{ha}$. A fixação biológica 
do $\mathrm{N}$ fornece de 25 a 608 do $\mathbf{N}$ total que as plantas adultas necessitam (MASCARENHAS et al., 1983).

De acordo com VERnETTI (1983)," para níveis de rendimento em torno de $2000 \mathrm{~kg} / \mathrm{ha}$ a necessidade de $\mathbf{N}$ pode ser suprida pela fixaçâo simbiótica. Para rendimento de gråos superiores a $3000 \mathrm{~kg} / \mathrm{ha}$, alguns autores, afirmam que há necessidade de nitrogênio de outras fontes para absorção pós-florescimento(HARPER, 1976 e REESE JR \& BUSS, 1992). Alguns produtores de soja da Virgínia, Estados Unidos, tentando obter produçōes máximas, adotaram o uso de fertilizante nitrogenado visando suplementar a fixação simbiótica.

REESE JR \& BUSS (1992) estudando esse sistema concluiram que a soja pode usar tanto o $\mathbf{N}$ combinado como o simbiótico mas, que a quantidade deste elemento produzido pelo rizóbio era inversamente relacionada com a quantidade de $\mathbf{N}$ combinado disponível. Quando era aplicada a dose preconizada pelos agricultores, $0 \mathrm{~N}$ combinado inibia a fixação simbiótica e não ocorria aumento no rendimento de grãos. BOUNIOLs et al. (1986) verificaram que presença de N residual reduzia ou suprimia a capacidade de fixaçăo das leguminosas em simbiose (EUECH \& BOUNIOLS, 1986 ).

O nitrato afeta, ao mesmo tempo, o processo de infecçåo, o desenvolvimento dos nódulos, a expressão da nitrogenase e, ativa os processos de envelhecimento dos nódulos. GIBSON \& HARPER (1985) observaram que se o 
nitrato é aplicado antes da inoculação, ele inibe o reconhecimento da soja pelo rizóbio e o estabelecimento dos nódulos. Segundo esses autores, a inibição depende mais da concentração do nitrato da solução do que da quantidade absorvida pela planta.

\section{ALCANTAR GONZALES \& TIRADO TORRES}

relataram que pequenas doses de nitrato no solo favoreciam - crescimento da planta mesmo quando inoculada, sobretudo nos primeiros estádios de crescimento vegetativo mas, até um limite próximo de ImMol. A mudança no efeito de inibidor para estimulador de nodulaçåo parece ocorrer entre 0,5 e ImMolar.

Com o cultivo da soja irrigada nas estações de outono-inverno no Estado de São Paulo, houve necessidade de se estudar melhor se há necessidade de se aplicar adubo nitrogenado. Os produtores de soja têm observado que a inoculação de sementes nåo tem sido capaz de suprir adequadamente a cultura instalada nessa época do ano. No entanto, TANAKA \& MASCARENHAS (1992) observaram nesse plantio redução da atividade simbiótica com a adição de $\mathbf{N}$ mineral como ocorre no plantio de verão. Na ausencia desse adubo, apesar de maior atividade simbiótica, esse tratamento nå resultou em produtividade de grăos semelhantes àqueles alcançados pela adubaçåo. HAM et al. (1975) mostraram que a aplicaçăo de $\mathbf{N}$ no solo inibia a 
nodulação mas aumentava a produtividade, sendo o teor de oleo no gråo, o único parâmetro reduzido.

EAGLESHAM et a1. (1982) observaram que quando foi adicionado ao solo $25 \mathrm{~kg} / \mathrm{ha}$ de $\mathbf{N}$, houve excelente nodulaçăo e alta atividade na redução do acetileno. Com a adição de $100 \mathrm{~kg} / \mathrm{ha}$ de $\mathbf{N}$ houve efeito adverso na formação e desenvolvimento do nódulo e na atividade da nitrogenase. A sintese proteica, ativada com a adição de $\mathbf{N}$ suplementar, utiliza esqueletos carbónicos para formar as moléculas de aminoácidos que seriam usados na síntese de açúcares da fotossintese, produtos da nutrição dos nódulos. Foi observado que a adição de quantidades maiores de $\mathbf{N}$ não aumentou, significativamente, o rendimento de grãos. O efeito desfavorável do $\mathbf{N}$ do adubo sobre a simbiose ocorre porque a adubação nitrogenada induz síntese de maior quantidade de proteína para o crescimento da planta o que acarreta desvios de produtos da fotossintese que iriam alimentar as bactérias dos nódulos.

BOSWELL \& ANDERSON (1969), BHANGOO \& ALBRITTON (1972) e HINSON (1975) mostraram resultados conflitantes quanto a resposta da produção à adição de N. ERANCo et al. (1978) mostraram que quando nåo foi adicionado $\mathbf{N}$ na forma de adubo, 408 do $\mathbf{N}$ total das plantas se devia a fixaçå mas, quando se forneceu $150 \mathrm{~kg} / \mathrm{ha}$, esse total abaixou para 16 웅 
SINCLAIR \& DE WIT (1975) observaram que 0 rendimento em grãos, que é consequencia da atividade fotossintética, é restringido pela ineficiencia das plantas em acumular $\mathbf{N}$ em quantidades suficientes à gerada para enchimento dos mesmos. Esses autores desenvolveram um modelo que postulava que o $\mathbf{N}$ disponivel para a planta, tanto de fontes internas como externas, limitava a produtividade de sementes. Concluiram que se houvesse aumento na quantidade do $\mathbf{N}$ total disponivel ocorreria um elongamento do período de enchimento e acarretaria um aumento na produção. Porém, quando o suprimento de $\mathbf{N}$ externo foi aumentado pela adição $\mathbf{N}$ na forma de adubo, a produção de soja não aumentou. O que ocorria era que o fertilizante nitrogenado reduzia o suprimento interno de $\mathbf{N}$, reduzindo a fixação de modo que, o $\mathbf{N}$ total disponível não aumentava.

UZIAKOWA (1959) \& UZIAK (1960) citados por HAM et a1. (1975) observou que a fonte de $\mathbf{N}$ que menos interfere com a nodulaçăo é a uréia. Segundo SUTTON (1993), a uréia quando espalhada sobre a superficie do solo, tende a hidrolizar-se rapidamente a carbonato de amonio que se decompõe em amoníaco e dióxido de carbono. O amoníaco se volatiliza e se perde. Essas perdas são variáveis mas, podem alcançar $60 \%$ do $\mathbf{N}$ aplicado. 


\subsection{EFEITO DO POTÁSSIO}

- potássio um dos elementos maís importantes na nutriçåo da soja pois atua sobre o metabolismo do $\mathbf{N}$ e sintese de proteina, além de outras funçóes fisiológicas.

YAMADA (1993) relatou que a falta de potássio na soja causava alto indice de acamamento, presença de haste verde, retençåo foliar, vagens chochas, o que reduzia a qualidade da semente e a produtividade da soja. MASCARENHAS et al. (1971) verificaram que a inclusão de potássio na adubaçåo em bases mínimas favorecia a retenção de vagens, reduzia a deiscéncia e, em combinação com o nitrogennio e fósforo, poderia aumentar o conteúdo de bleo das sementes.

MÁLAVOLTA \& CRÓCOMO (1982) verificaram que tanto

fatores internos como os externos da planta influenciam a velocidade de absorção de potássio podendo citar o fator genético, a idade, taxas de crescimento, de respiraçăo e transpiraçăo, a aeraçăo do solo e, a presença de ions como magnésio e cálcio.

os fatores que limitam a resposta à adiçáo de potássio såo:

a) presença de quantidades adequadas para um crescimento ótimo;

b) presença de outros fatores limitantes da produçăo.

- potássio tem ainda papel importante na simbiose parecendo que seu efeito na nodulaçăo e na fixação e 
indireto. Como a resposta à adubação potássica é variável pode-se esperar que exista uma correlação positiva ou nula entre as taxas de fixação de $\mathbf{N}$, o número e a massa nodular com doses de potássio.

DUKE \& COLLINS (1985) relataram que os efeitos positivos do potássio na fixação do $\mathbf{N}$ parecem ser devidos aos aumentos da taxa de fotossintese, do transporte de fotoassimilados ao nódulo, do aumento do crescimento da raiz ou pela combinação desses fatores induzidos pela nutriçåo potássica.

o potássio não tem efeito sobre a massa nodular. - fato não indica, necessariamente, que este elemento não afete a fixação de nitrogennio pois, esta é função da produtividade do nódulo. Embora o número e a massa de nódulos sejam úteis para verificar os efeitos de potássio na fixação de nitrogênio, sozinhos são insuficientes para compreensão total do fenomeno. JONES et al. observaram que a aplicação de potássio aumentava o número de nódulos por planta e por unidade de volume. O número, o peso total e individual do nódulo foram também aumentados pelo potássio. Esses autores observaram ainda que com a aplicação de potássio a sua concentração nos nódulos aumentava mas, tinha pouca influência na concentração de $\mathbf{N}$, P, Ca, Cu, Fe, Mn e Zn e diminuia a de Mg. 
RAPER JR \& BARBER (1970) observaram que a eficiência na absorção de potássio é dependente do cultivar - da concentração na solução.

DE MOOY \& PESEK (1966) demonstraram que os genótipos de soja têm exigências à nutrição potásica diferentes na nodulaçåo durante o desenvolvimento da planta. Porém, a maioria dos autores concorda que não há evidência alguma sobre o aumento da eficiência do nódulo devido a K. Embora vários pesquisadores tenham relatado que - acúmulo de $\mathbf{N}$ seja responsivo à adubaçăo potássica, quando ocorre deficiência de $\mathbf{k}$ nas leguminosas não há sintoma de deficiência de N (ANDREW \& BRIAN, 1955). Essa deficiência é, geralmente, associada com concentraçôes de $\mathbf{N}$ na folha ou no grao (ou ambos) iguais ou superiores àquelas de plantas que cresceram com potássio suficiente para que obtivessem produçớes ótimas.

MUZILLI (1982) verificou que a curva de acumulação de $\mathbf{K}$ acompanhava a produçâo de matéria seca sendo a velocidade de absorção mais acentuada nos primeiros trinta dias que precederam ao florescimento. Isso sugere que a deficiencia de $\mathbf{K}$ nao limita fatores da planta que, subsequentemente, limitariam àqueles parâmetros.

MASCARENHAS et al. (1982) aconselham aplicaçơs anuais para restituir as quantidades extraídas e favorecer a retenção e a redução de deiscência das vagens, 
contribuindo ainda para melhorar a qualidade das sementes e aumentar a resistência das plantas às doenças.

De maneira geral, a reserva de potássio nos solos nåo é suficiente para suprir a quantidade extraída pela cultura da soja por longos periodos. Assim, o seu suprimento às plantas deve ser feito através de adubaçåo potássica. 


\section{MATERIAL E MÉTODOS}

\subsection{LOCAL DE CONDUÇÃO DO EXPERIMENTO E CARACTERÍSTICAS DO SOLO}

- experimento foi instalado nas Estações Experimentais de Mococa, Ribeirå Preto e Votuporanga, do Instituto Agronômico do Estado de são Paulo. Os solos de Mococa, Ribeirå Preto e Votuporanga possuem caracteristicas diferentes e foram classificados como: Mococa: Podzólico Vermelho-Escuro, eutrófico, A moderado, Tb, textura argilosa ou muito argilosa (LEPSCH) ${ }^{1}$.

RIBEIRAO PRETO: Latossolo Roxo, eutrófico, A moderado, textura muito argilosa (OLIVEIRA \& PRADO, 1983).

Votuporanga: Latossolo Vermelho-Escuro, cambico, eutrófico, A moderado, textura media (PRADO \& JORGE) ${ }^{2}$.

os resultados das análises quimicas do solo das areas onde foi instalado o experimento sao apresentados na Tabela 1.

1 IEPSCH, I.F. Comunicaçáo pessoal, 1993.

2 PRADO,H. \& JORGE,J.A. Levantamento pedológico detalhado e caracterizaçáo físico-hídrica dos solos da Estação Experimental de Votuporanga. Campinas, Instituto Agronomico (boletim técnico, no prelo). 
Tabela 1. Resultado das análises químicas da camada superficial do solo $(0-20 \mathrm{~cm})$ das áreas experimentais.

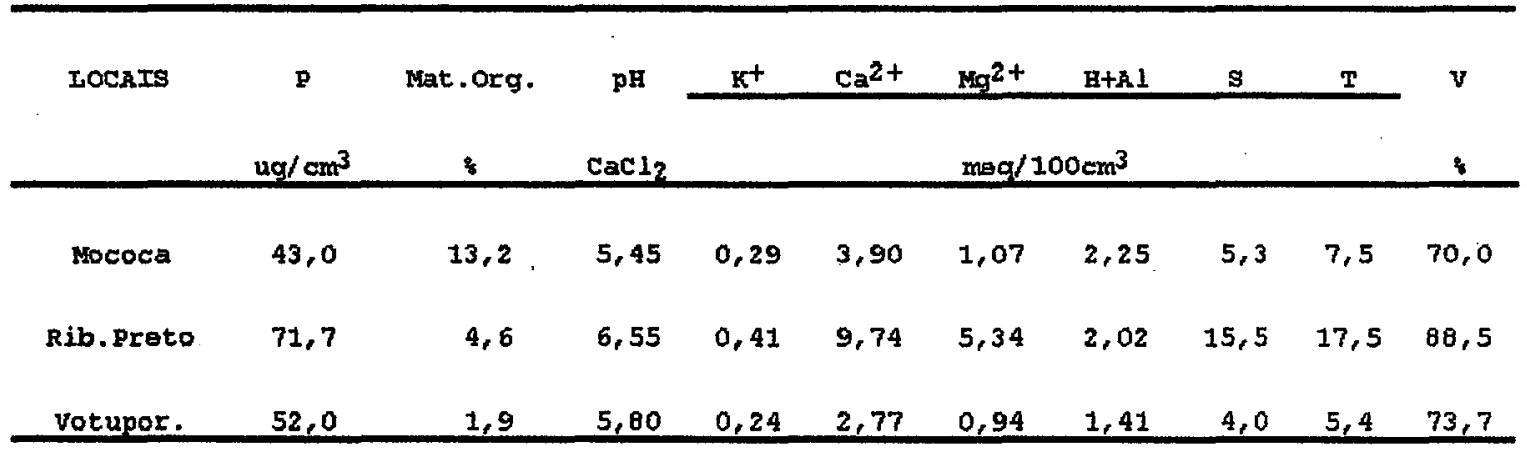

\subsection{PREPARO DO SOLO}

- solo para o cultivo da soja foi preparado no sistema convencional, com araçăo e gradagem. Cultivos anteriores feitos nas áreas experimentais foram adubados para obter máximas produtividades, o que explicaria o alto teor de fósforo e de potássio no solo.

\subsection{TRATAMENTOS E CARACTERISTICAS DAS PARCELAS}

o delineamento experimental empregado foi em

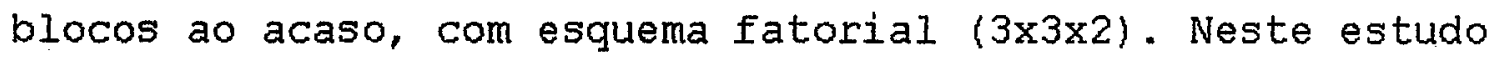
foram utilizados tress doses de nitrogênio - $0\left(\mathbf{N}_{0}\right), 50\left(\mathbf{N}_{1}\right)$ e $100\left(\mathbf{N}_{2}\right) \mathrm{kg} / \mathrm{ha}$ de $\mathbf{N}$-, três doses de potássio - $0\left(\boldsymbol{K}_{\mathbf{0}}\right)$, $30\left(\mathbf{K}_{1}\right)$ e $60\left(\mathbf{K}_{2}\right) \mathrm{kg} / \mathrm{ha}$ de $\mathbf{K}_{2} \mathrm{O}$ - e dois cultivares de soja (IAC-8 e IAC-14). 
Como fontes de $\mathbf{N}$ e de $\mathbf{K}$ foram utilizados, respectivamente, uréia e cloreto de potássio. Um terço da dose dos dois nutrientes foi aplicado em cobertura e em faixas, dez dias após a germinação e o restante vinte dias após. Os adubos foram levemente recobertos com solo para evitar perdas por volatilização.

As parcelas eram compostas por quatro linhas de seis metros espaçadas em $0,60 \mathrm{~m}$. Entre parcelas foi deixado um espaço de dois metros sem plantio. As duas linhas centrais foram mantidas para avaliação da produção e as duas laterais foram sorteadas para a amostragem.

\subsection{TRATOS CULTURAIS}

As datas da semeadura, germinação, florescimento e colheita da soja dos trés locais såo apresentados na Tabela 2 .

Foram semeadas 30 sementes por metro linear, inoculadas com Bradyrhizobium japonicum. Utilizou-se inoculante turfoso comercial (NITRAL - Indústria e Comercio de Inoculantes e Produtos Agropecuários Ltda) na base de 5 gramas por quilograma de sementes. As estirpes empregadas foram a SEMIA 587 e a SEMIA $5019(=W-29)$. No estádio de plantula foi realizado desbaste de modo a serem mantidas vinte plantas por metro linear. 
Tabela 2. Datas da semeadura, germinação, florescimento e colheita dos cultivares de soja IAC-8 e IAC-14 em Mococa, Ribeirão Preto e Votuporanga.

\begin{tabular}{cccc}
\hline $\begin{array}{c}\text { ESTADIOS DE } \\
\text { DESENVOLVIMENTO }\end{array}$ & MOCOCA & RIBEIRAO PRETO & VOTUPORANGA \\
\hline SEMEADURA & $29 / 5 / 91$ & $6 / 6 / 91$ & $18 / 6 / 91$ \\
GERMI NACAO & $10 / 6 / 91$ & $17 / 6 / 91$ & $26 / 6 / 91$ \\
FLORESCIMENTO & $12 / 8 / 91$ & $88 / 8 / 91$ & $16 / 8 / 91$ \\
COLHEITA & $8 / 11 / 91$ & $1 / 11 / 91$ & $24 / 10 / 91$ \\
\hline
\end{tabular}

Como a produção de soja é limitada pelo deficit hídrico (FOROUD et al.,1993) e durante o inverno a precipitação é escassa, o experimento foi irrigado por aspersão, sempre que apareciam sintomas iniciais de deficiencia hídrica nas plantas.

No decorrer do desenvolvimento da cultura foram efetuadas capinas manuais.

Em Mococa e Ribeirå preto houve necessidade de controlar percevejos. Em Mococa foi realizada uma aplicaçăo de monocrotofós na dose de $150 \mathrm{~g} / \mathrm{ha}$ e 5 aplicaçơes de endossulfan a $525 \mathrm{~g} / \mathrm{ha}$ em $6 / 9 / 91,13 / 9 / 91,18 / 8 / 91,26 / 9 / 91$ - 2/10/91. Em Ribeirå preto foram feitas quatro aplicaçסes de endossulfan a $525 \mathrm{~g} / \mathrm{ha}$ em 15/8/91, 27/8/91, 26/9/91 e 11/10/91. Em Votuporanga nao houve necessidade de controlar pragas. 


\subsection{AMOSTRAGENS DAS PLANTAS E DETERMINAÇÕES}

A amostragem foi realizada nos três locais, na época do florescimento pleno das plantas: no estádio $R_{1}$ segundo COSTA \& MARCHESAN (1982) ou R5 segundo HANWAY \& THOMPSON (1971).

Para a amostragem foram escolhidas três plantas representativas da parcela dentro da linha sorteada. Foram avaliadas as matérias secas da parte aérea e de nódulos, o número de nódulos, os teores de $\mathbf{N}$ e de $\mathbf{K}$ da parte aérea e a atividade da nitrogenase dos nódulos das raizes de três plantas da amostra.

\subsection{MÉTODOS ANALÍTICOS}

As raizes foram separadas das partes aereas na regiáo do colo do nó cotiledonar e imediatamente usadas para medir a atividade da nitrogenase, usando-se o metodo da redução do acetileno, desenvolvido por HARDY et al. (1973) e modificado por PATTERSON \& LARUE (1983).

No laboratório, as raizes com os nodulos foram lavadas, os nódulos retirados, contados, secos a $65{ }^{\circ} \mathrm{C}$ em estufa e pesados.

As partes aéreas foram lavadas com água destilada, secas em estufa a $65^{\circ} \mathrm{C}$, pesadas e moidas 
finamente em moínho tipo Wiley para avaliaçåo posterior dos seus teores de $\mathbf{N}$ e $\mathbf{K}$.

As determinações dos teores de $\mathbf{N}$ e $\mathbf{K}$ da parte aérea foram efetuadas pelo método descrito por BATAGLIA et a. (1978).

\subsection{COLHEITA}

Visando à obtenção de dados de rendimento de grãos, foram colhidas a duas linhas centrais descontando-se $0,5 \mathrm{~m}$ das extremidades. A seguir, os grăos foram limpos, moidos em moinho do tipo wiley, determinando-se o seu teor em $\mathbf{N}$ pelo mesmo método utilizado para a parte aerea.

\subsection{ANÁLISE ESTATÍSTICA}

$\mathrm{Na}$ análise estatística de variancia e dos dados desse experimento utilizou-se o programa estatístico SANEST .

- efeito dos tratamentos para cada local foi verificado pelo teste $F$. As médias de cultivares foram comparadas pelo teste de Tukey. Para a análise das doses de N e $\mathbf{K}$ foi usada regressão polinomial. Neste trabalho, somente foram comentados os desdobramentos da análise de regressão polinomial significativos pelo teste $\mathrm{F}$. 
Não foi realizada análise conjunta para locais pois os dados mostraram ser heterogêneos pelo teste de HARTLEY para alguns parâmetros (NOGUEIRA, 1991). 


\section{RESULTADOS E DISCUSSÃo}

\subsection{EEEITO DE CULTIVAR}

Nas três localidades estudadas não houve diferença entre cultivares, quanto aos teores de $\mathbf{N}$ e de $\mathbf{K}$ da parte aerea (Tabelas 3, 8 e 13). Em Mococa, também não houve diferença quanto a materia seca da parte aerea, atividade total do nódulo e o teor de $\mathbf{N}$ no grá (Tabela 3). Em Ribeiråo Preto, năo houve diferença quanto a materia seca da parte aérea e o rendimento de grãos nos dois cultivares (Tabela 8 ).

HANWAY \& WEBER (1971a e b) verificaram que o acúmulo de $\mathbf{N}$ nas plantas segue padrăo similar ao da matéria seca e portanto, a semelhança entre cultivares para materia seca e 8 de $\mathbf{N}$ da parte aérea já era esperada.

MUZILLI (1982) relatou o mesmo comportamento para potássio. Os teores de $\mathbf{K}$ encontrados na parte aérea em ambos os cultivares foram superiores aos valores medios citados por MASCARENHAS et al. (1980). Já os teores de $\mathbf{N}$ no gră foram inferiores em Mococa e superiores em Votuporanga aos obtidos por HAMMOND (1949) que variaram de 6,20 a 6,308. Embora nåo tenha ocorrido diferença entre cultivares 
no rendimento de grăos de Ribeirão preto, verificou-se maior acúmulo de $\mathbf{N}$ no cultivar IAC-8.

Em Votuporanga, também não houve diferença entre cultivares quanto ao teor de $\mathbf{N}$ e $o$ rendimento de grão (Tabela 13). No entanto, MASCARENHAS et al. observaram que cada cultivar de soja tem exigencia nutricional própria e diferente capacidade de extração de nutrientes fato que não ocorreu no presente estudo quanto ao teor de $\mathbf{N}$.

\subsubsection{MOCOCA}

Pelos dados da tabela 3, pode-se observar que IAC-8 produziu mais nódulos e estes tinham mais materia seca que o IAC-14 entretanto, năo houve diferença entre cultivares quanto a atividade da nitrogenase. CALDWELL \& VEST (1968) mostraram que existem diferenças significativas entre genótipos de soja quanto a sua aceitaçå por Bradyrhizobium japonicum, e que essa especificidade em relaçăo a bacteria e à planta ocorre ao nivel de cultivar, - que explicaria a diferença obtida nesse experimento.

Quanto ao rendimento de gråos, observou-se que embora o IAC-14 tenha sido mais produtivo que o IAC-8, esta foi bem inferior a media de verao do Estado de săo paulo, em 1991, que foi de $2134 \mathrm{~kg} / \mathrm{ha}$ (CARRIERI et al., 1993). 


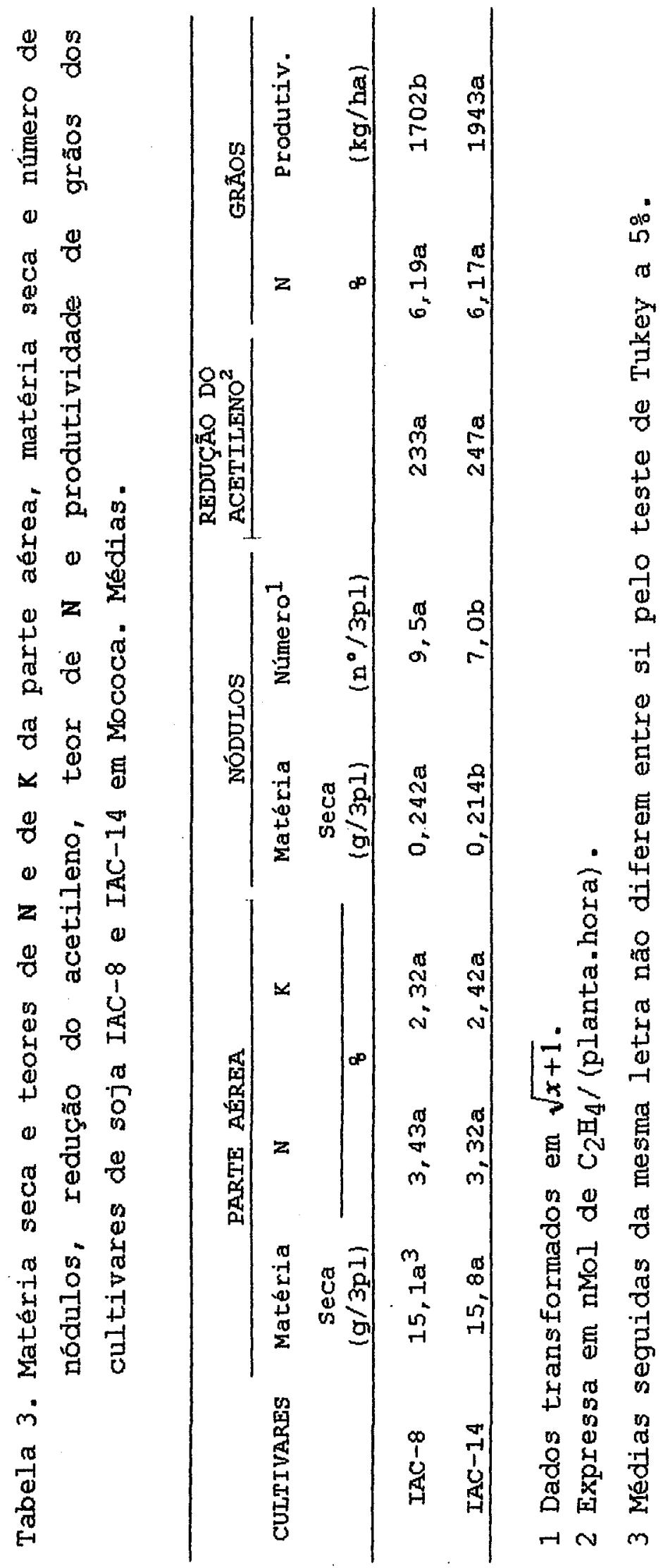




\subsubsection{CULTIVAR DENTRO DE DOSES DE NITRO- GÂNIO}

Quando se avaliou a interaçăo de cultivares dentro de doses de $\mathbf{N}$ (Tabelas 4 e 5), observou-se que sem nitrogenio $\left(N_{0}\right)$, o cultivar IAC-8 foi superior ao IAC-14 quanto a nodulaçăo e a atividade total do nódulo (Tabela 5).

Quando a dose de $\mathbf{N}$ foi aumentada para $50 \mathrm{~kg} / \mathrm{ha}$ $\left(\mathbf{N}_{1}\right)$, somente houve diferença entre cultivares quanto ao teor de $\mathbf{x}$ da parte aérea (Tabela 4) e quanto ao número de nódulos e atividade total do nódulo (Tabela 5). O teor de $\mathbf{k}$ da parte aerea foi maior no IAC-14 (Tabela 4). IAC-8 produziu maior número de nódulos que IAC-14 mas, estes tiveram atividade total do nódulo menor.

Vários autores mostraram que há relaçao inversa entre a aplicaçăo de $\mathbf{N}$ mineral e a nodulaçăo e fixaçăo simbiotica de nitrogenio em soja. VERNETTI (1983) relatou que quando o $\mathbf{N}$ e absorvido do solo ou de fertilizantes incorporados, a planta utiliza certa quantidade de fotoassimilado que antes ficava disponivel ao nódulo para aumentar seu crescimento e para sintetizar proteina. Essa reduçăo de fotoassimilado resulta em decréscimo na fixaçăo do $\mathbf{N}$.

Com a aplicaçå de $\mathrm{N}_{2}$, o rendimento de grăos foi maior no IAC-14 mas, o número de nódulos foi menor nesse 


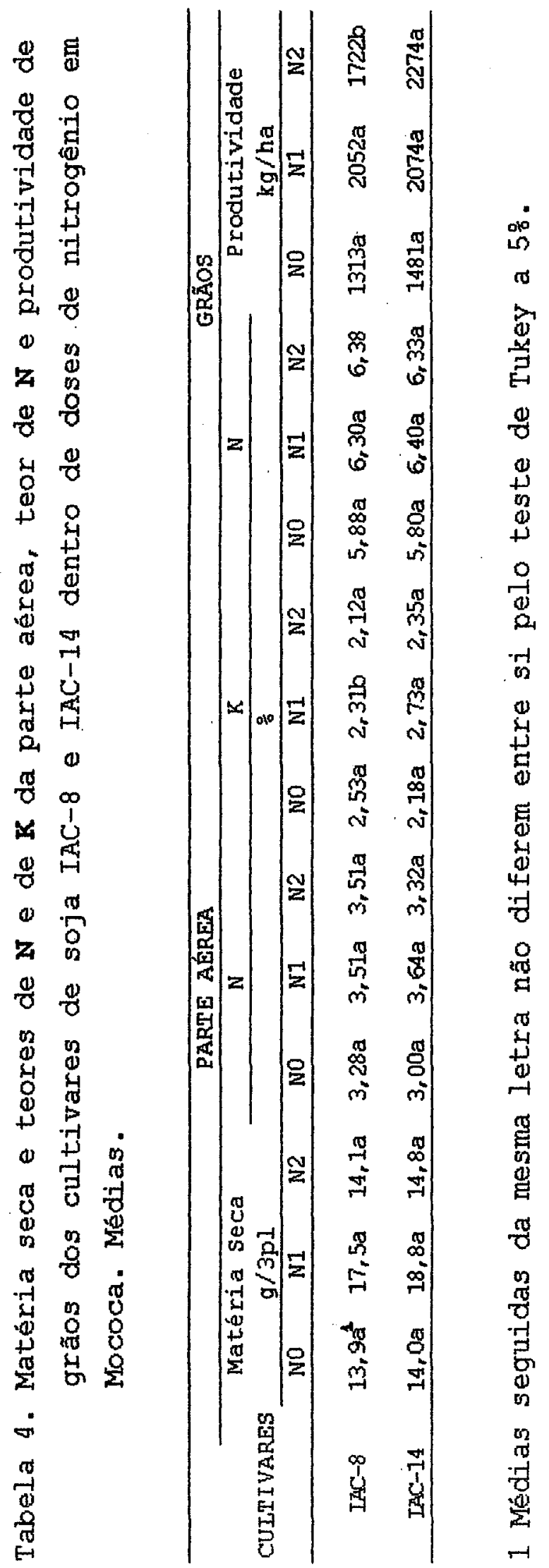




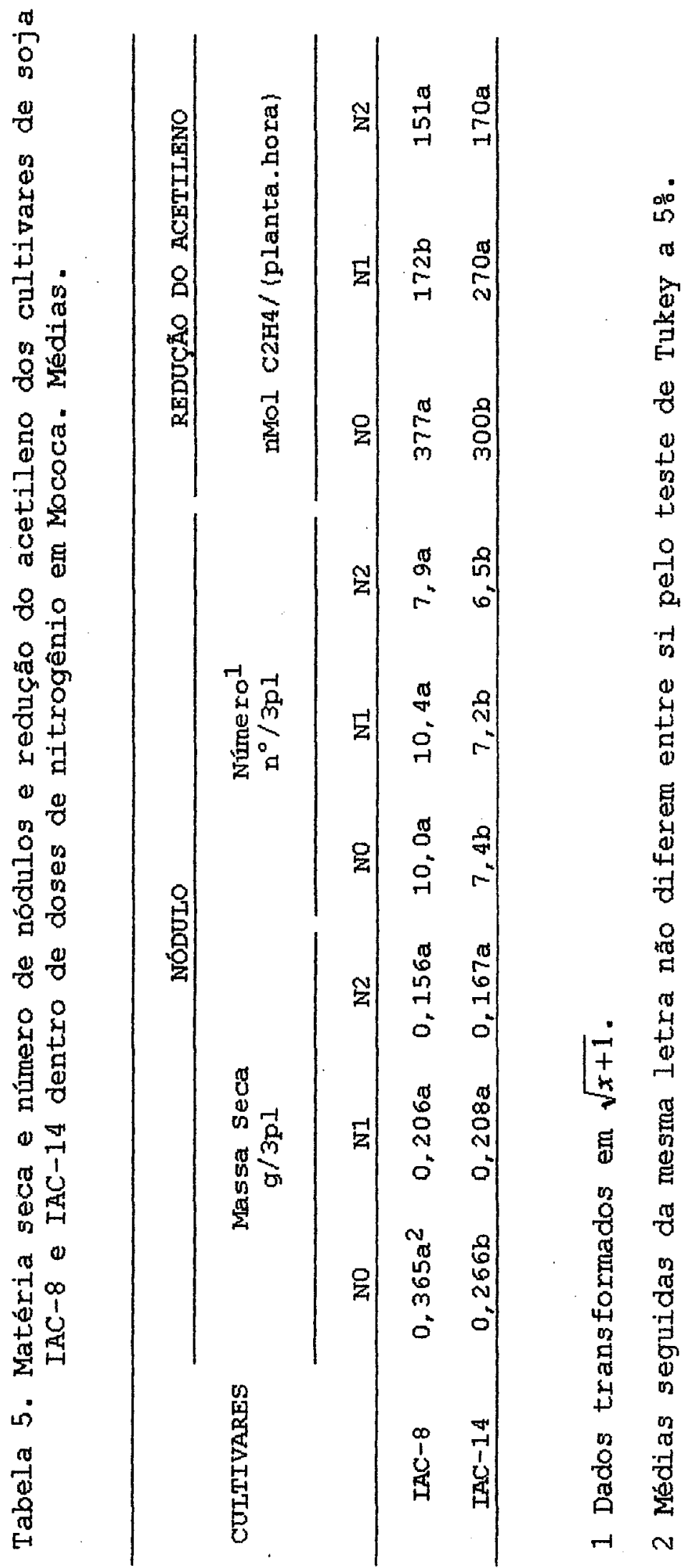


cultivar. IAC-8 e IAC-14 produziram quantidades similares de grãos com $\mathbf{N}_{0}$ e $\mathbf{N}_{1}$ mas, quando se adicionou $\mathbf{N}_{2}$, IAC-14 produziu $551,56 \mathrm{~kg} / \mathrm{ha}$ a mais que IAC-8 indicando que este cultivar responde diferentemente ao elevado fornecimento de nitrogênio.

\subsubsection{CULTIVAR DENTRO DE DOSES DE PO- TÁSSIO}

os dados relativos a interação entre cultivares dentro de doses de $\mathbf{K}$ såo apresentados nas tabelas 6 e 7 .

Sem a adubação potássica verificou-se que o IAC-8 teve maior nodulaçăo e maior atividade total do nódulo que IAC-14 (Tabela 7).

Verificou-se que apenas a dose $\mathbf{k}_{\mathbf{1}}$ afetou a matéria seca da parte aérea. Foi observado melhor desenvolvimento do cultivar IAC-14 quanto a materia seca da parte aérea, atividade total do nódulo e no rendimento de grăos. Nessa dose, IAC-8 teve melhor desempenho somente quanto ao número de nódulos. Entretanto, MASCARENHAS et al. (1976) relataram que a produtividade nao reage positivamente à aplicaçăo de $\mathbf{K}$. A aplicaçăo deste nutriente deve ser normalmente feita para restituir o que foi retirado do solo, favorecendo a retenção de vagens e melhorando a qualidade da semente.

DUKE \& COLLINS (1985) relataram que em solos onde 


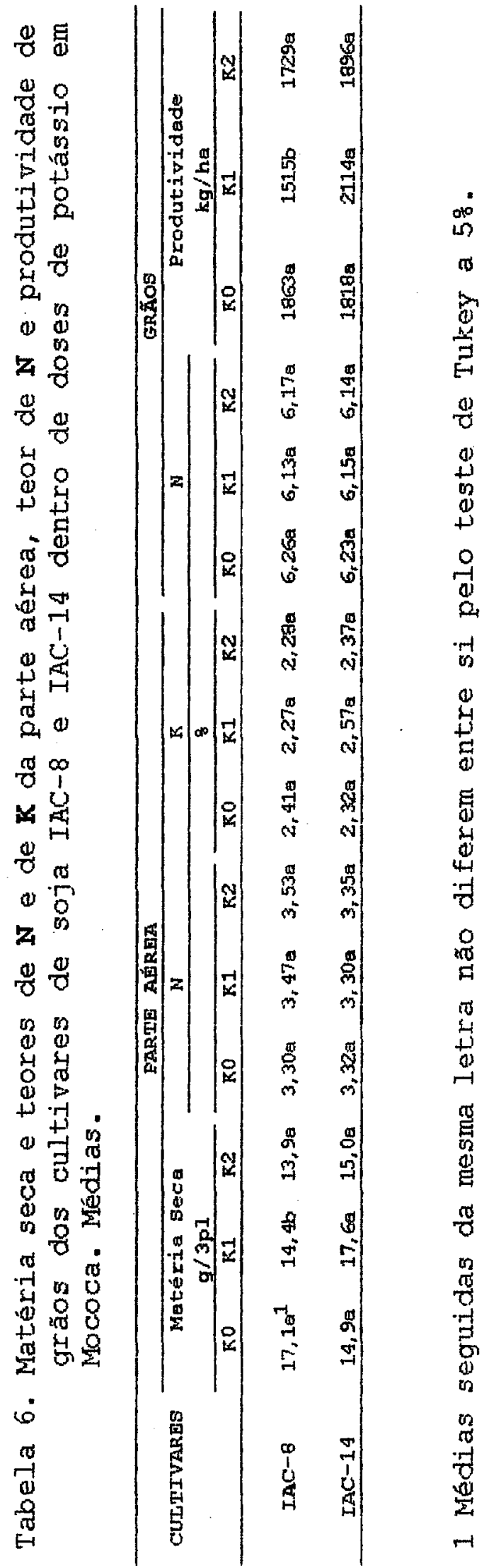




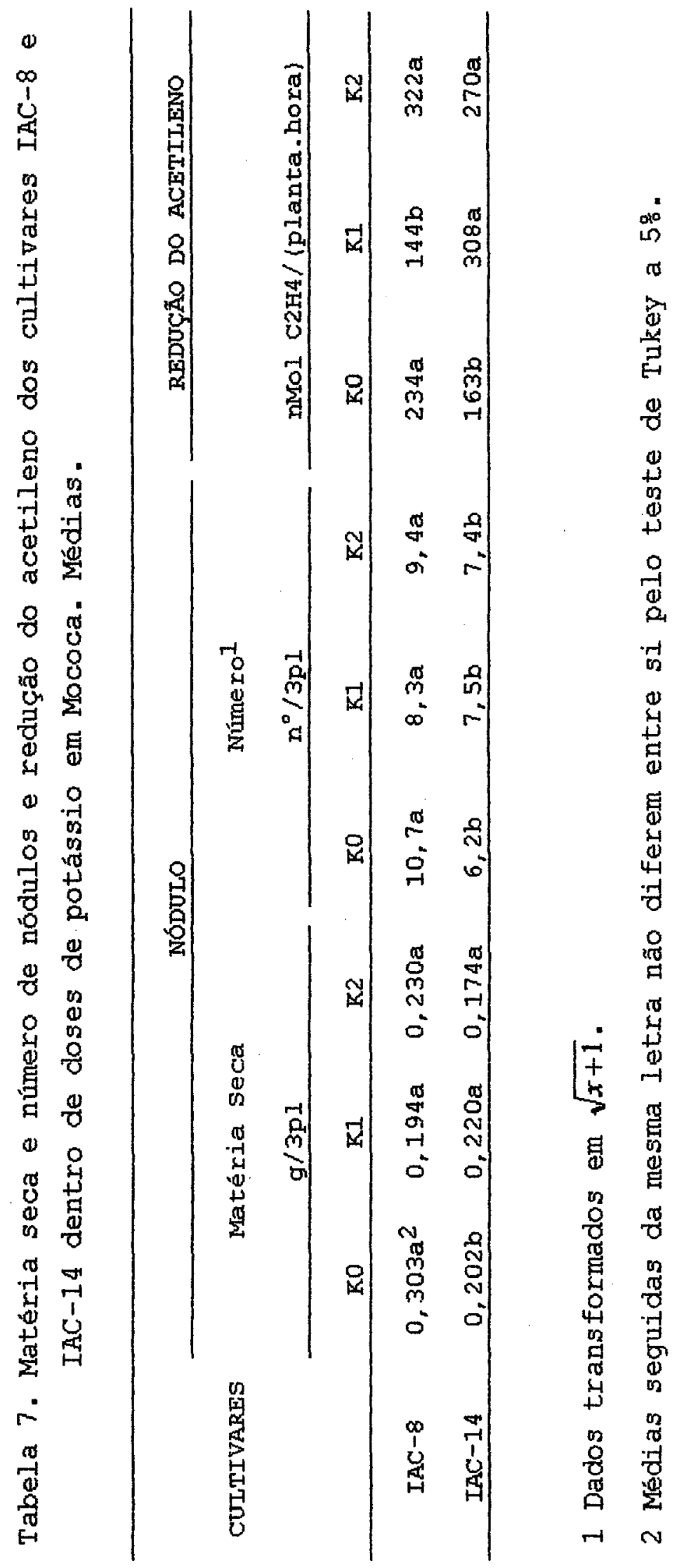


há quantidades adequadas de $\mathbf{K}$ (como os solos estudados nesse trabalho) o aumento na concentração desse elemento nos tecidos é moderada. RITCHEY et al. (1979) acrescentaram que só há respostas positivas à adição de $\mathbf{K}$, em 908 dos casos, em solos com menos de 0,15 emg/100 ml de solo.

- cultivar IAC-8 produziu maior número de nódulos em todas as doses utilizadas inclusive quando foi adicionado $\mathbf{K}_{\mathbf{2}}$.

\subsubsection{RIBEIRÃO PRETO}

Os cultivares năo apresentaram diferenças significativas para os parametros fisiológicos avaliados (Tabela 8). Apenas o teor de $\mathbf{N}$ no grăo foi maior no cultivar IAC-8. As diferenças entre cultivares aparecem nos parametros da fixação simbiótica.

A nodulaçăo e atividade total dos nódulos foram estatíticamente maiores no cultivar IAC-8 (Tabela 8). JIMENEZ et al. (1991) relataram que a melhor nodulação de um cultivar está relacionada com a preferencia deste a uma determinada estirpe. VERNETTI (1971) verificou que em soja, a capacidade de fixar $\mathbf{N}$ simbioticamente de uma estirpe de rizóbio varia de cultivar para cultivar, isto 6 , há uma variaçăo hereditária dependendo da constituição genetica das plantas em relação à bactéria. 


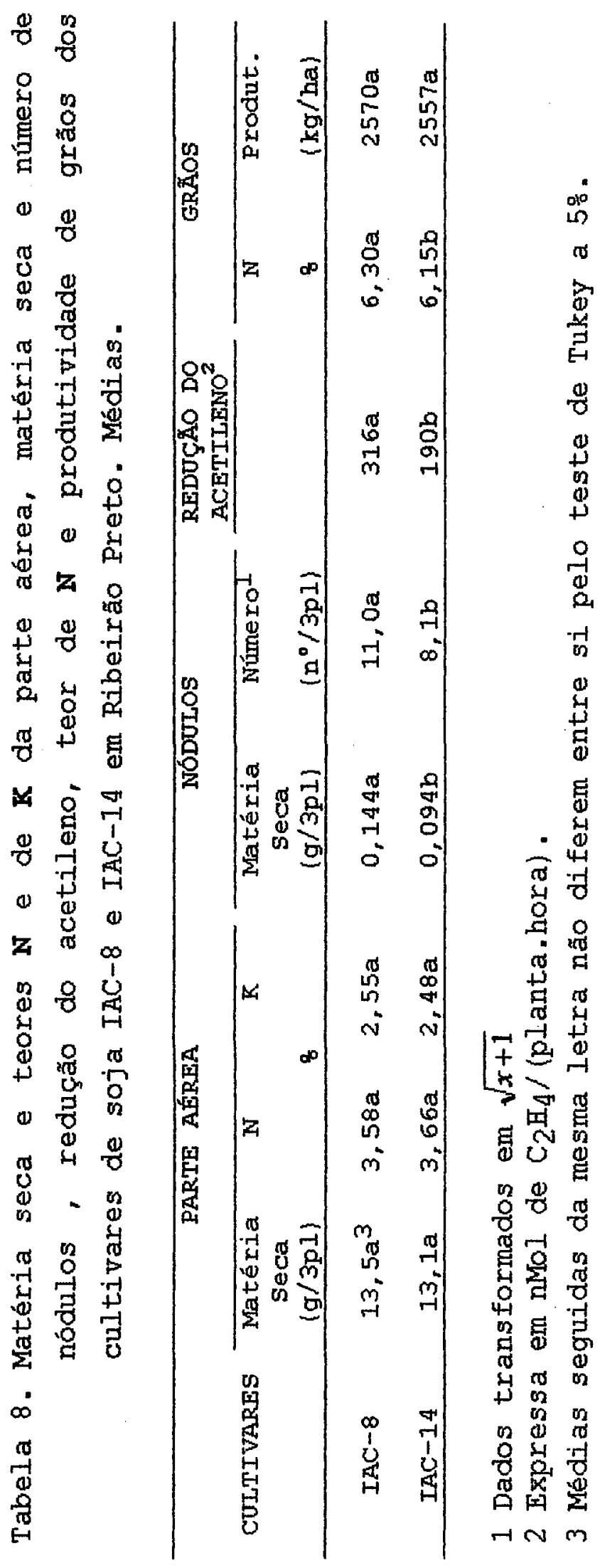




\subsubsection{CULTIVAR DENTRO DE DOSES DE NITRO- GÊNIO}

As Tabelas 9 e 10 mostram que, embora nem sempre tenha havido diferença estatística, se observou maiores materias secas da parte aerea e de nódulos, número de nódulos, atividade total do nódulo e de $\mathbf{N}$ no grăo no cultivar IAC-8 para quaisquer das doses de $\mathbf{N}$ aplicadas. Sem adiçåo de $\mathbf{N}\left(\mathbf{N}_{0}\right)$, essa diferença entre cultivares é significativa apenas para matéria seca, número e atividade total do nódulo; com adição de $\mathbf{N}_{1}$ para número de nódulo; com $\mathbf{N}_{2}$ para massa seca e número de nódulos. O teor de $\mathbf{N}$ da parte aerea no tratamento No mostrou superioridade do cultivar IAC-14.

\subsubsection{CULTIVAR DENTRO DE DOSES DE POTÁSSIO}

Em relação à interação entre cultivares dentro de doses de $\mathbf{K}$ (Tabelas 11 e 12) verificou-se, que IAC-8 teve maior número de nódulo quando nåo foi adicionado $\mathbf{k}$. Com a adiçáo de $\mathbf{K}$, IAC-8 mostrou superioridade quanto a matéria seca e número de nódulos com quaisquer das doses aplicadas. Houve maior acúmulo de $\mathbf{N}$ no grao e maior atividade total do nódulo no cultivar IAC-8 quando da adiçăo de $\mathbf{k}_{2}$. Nos parametros agronômicos não houve interaçăo significativa (Tabela 11). 


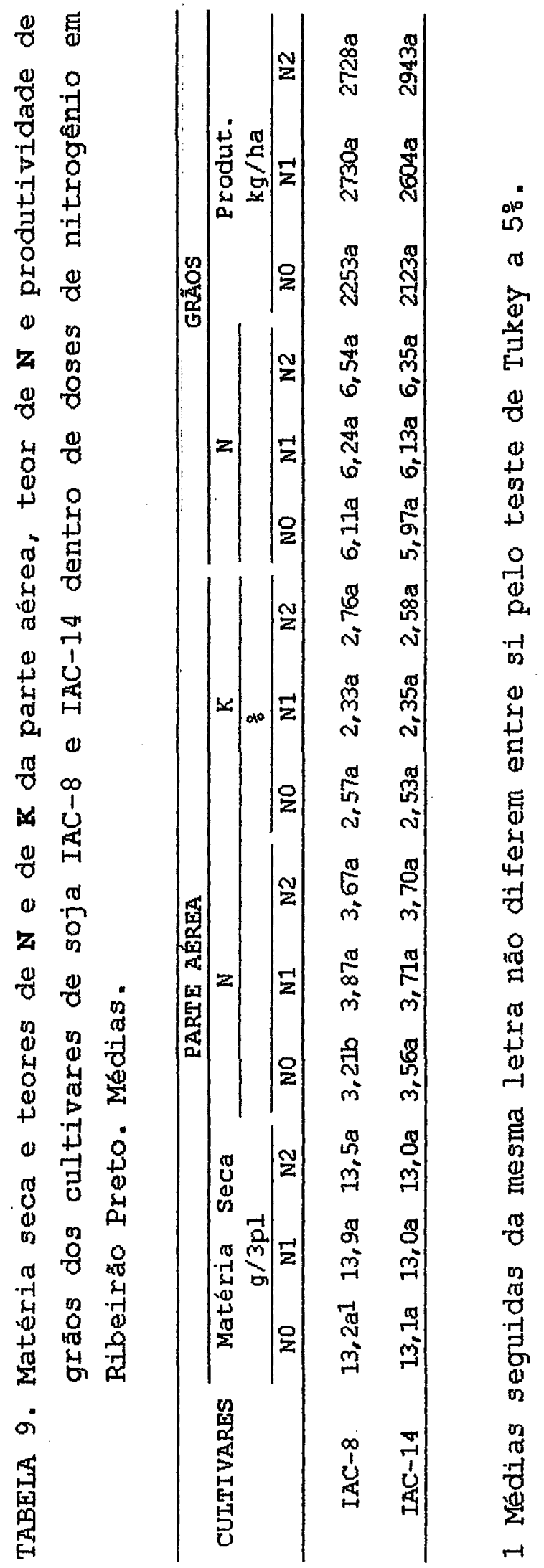




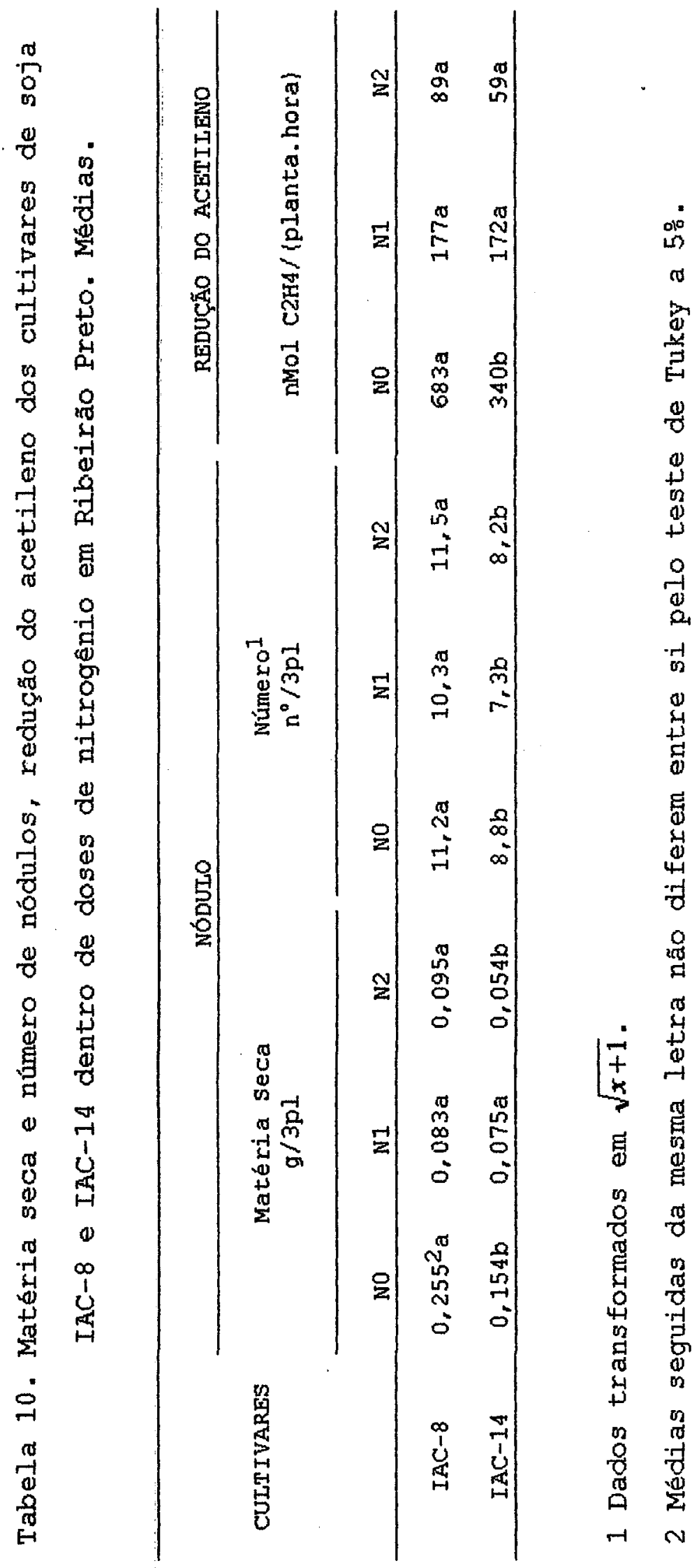




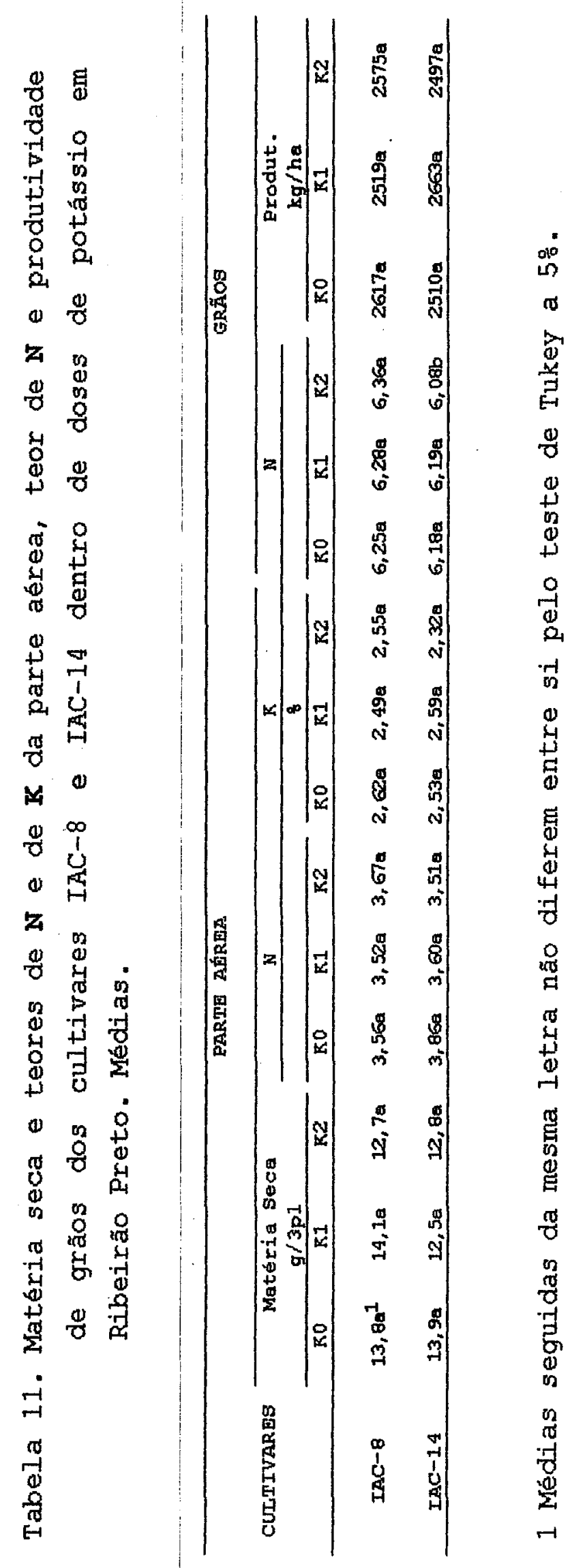




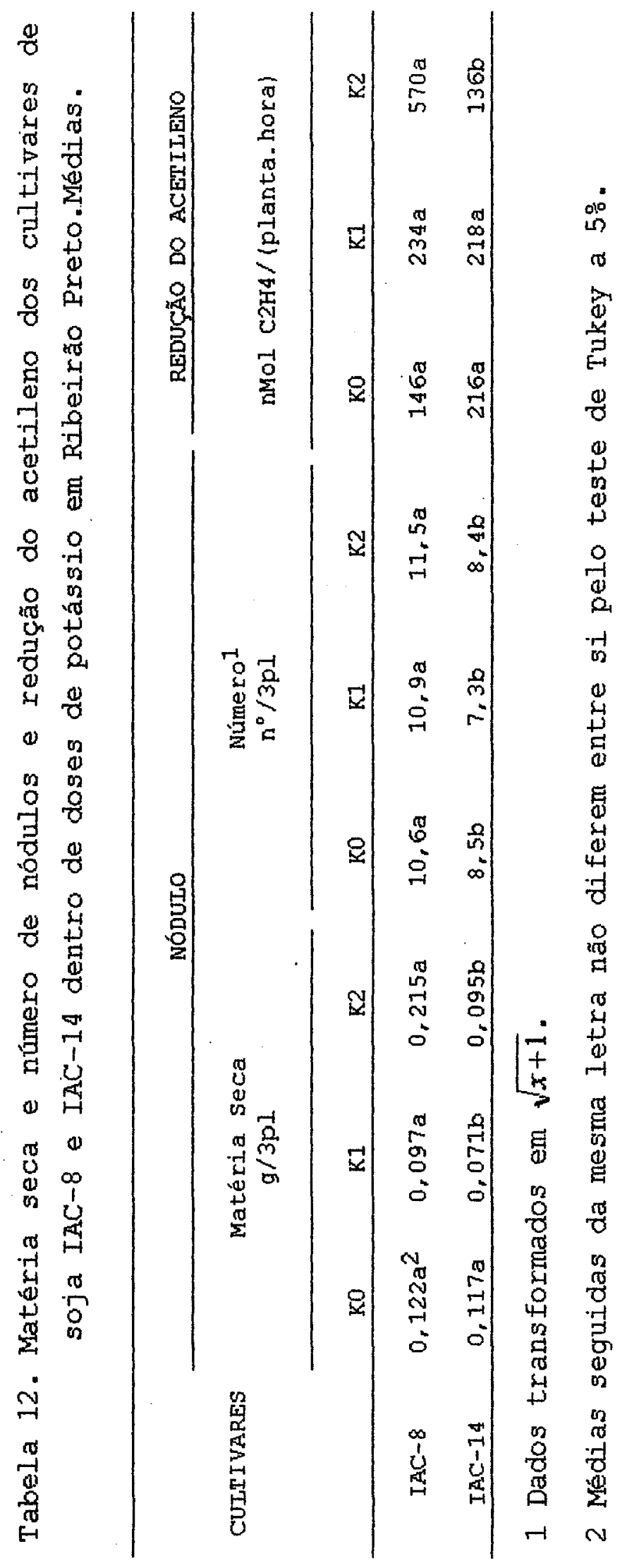




\subsubsection{VOTUPORANGA}

Pelos dados da Tabela 13, verificou-se que houve diferença significativa entre cultivares para as matérias secas da parte aérea e de nódulos, número de nódulos e atividade total do nódulo. Em todos os parămetros onde houve diferença estatística, IAC-8 respondeu melhor que IAC-14. Nas condições edafoclimáticas de Votuporanga, onde se tem solo típico de cerrado esse fato não causa estranheza visto que, MIRANDA et al. (1980) desenvolveram o cultivar IAC-8 para ser cultivado nessa condição.

\subsubsection{CULTIVAR DENTRO DE DOSES DE NITRO- GÊNIO}

- efeito da interaçao de cultivar dentro de doses de $\mathbf{N}$ nas condiçoses de votuporanga sao apresentadas nas Tabelas 14 e 15 .

A matéria seca da parte aérea foi maior em IAC-8 nos tratamentos $\mathbf{N}_{0}$ e $\mathbf{N}_{\mathbf{1}}$, nåo havendo diferença entre cultivares com a adição de $\mathbf{N}_{2}$ (Tabela 14).

Houve efeito de cultivar na nodulação devido a aplicação de nitrogênio (Tabela 15). Verificou-se que IAC-8 produziu mais massa nodular que IAC-14 nos tratamentos sem nitrogenio ou onde foi aplicado $\mathbf{N}_{1}$. Já o número de nódulos, com quaisquer das doses de nitrogénio aplicadas foi maior no cultivar IAC-8. 


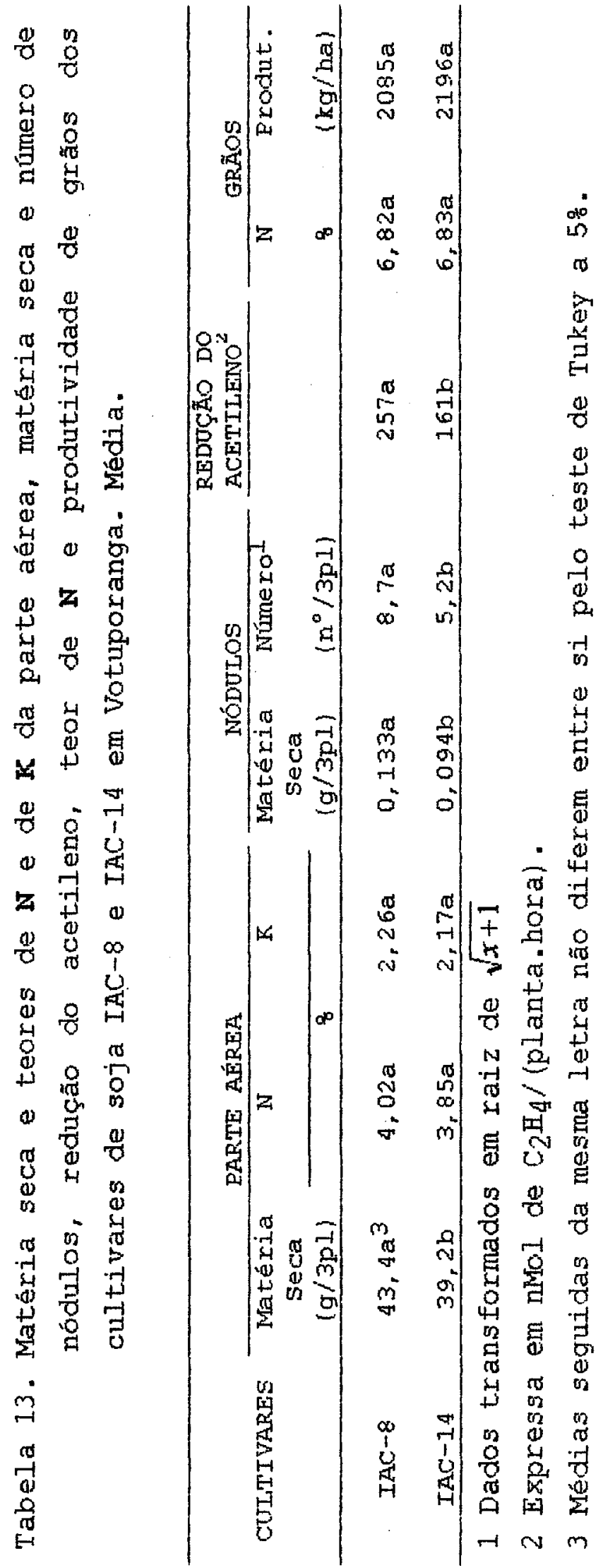




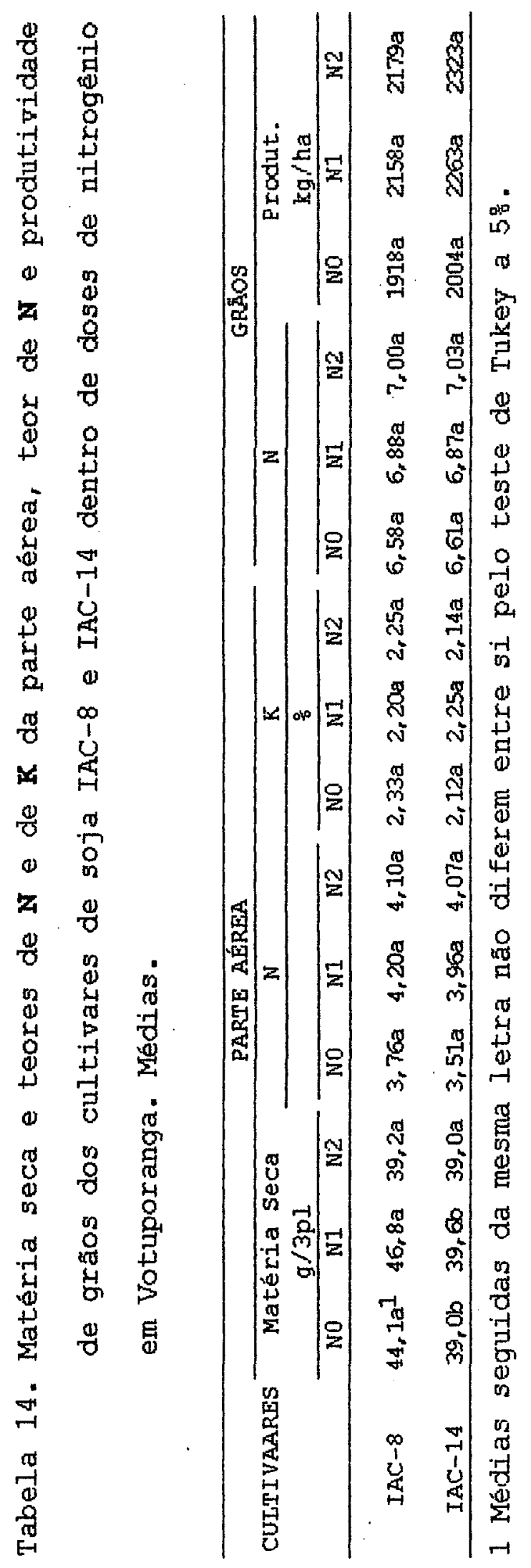




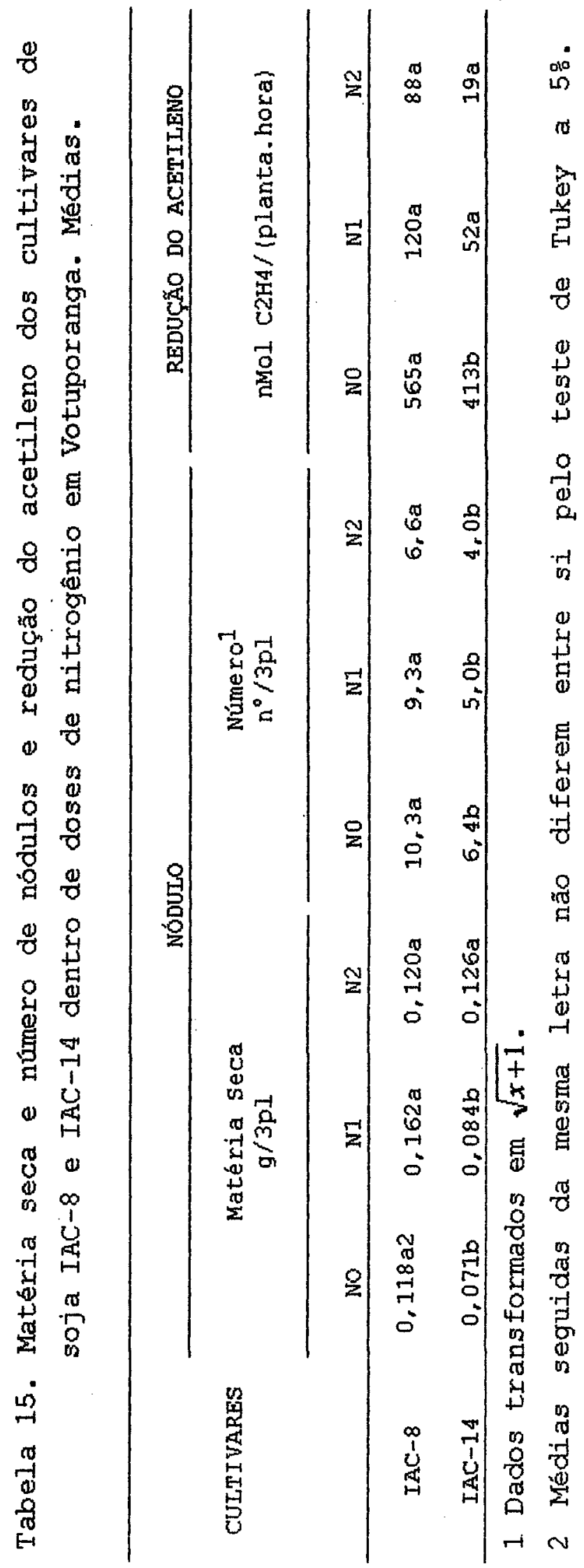


Pode-se observar ainda que houve diferença entre cultivares quanto à atividade total do nódulo na dose $\mathbf{N}_{0}$ sendo que, o cultivar IAC-8 apresentou maior atividade total de nódulo na dose No (Tabela 15).

\subsubsection{CULTIVAR DENTRO DE DOSES DE PO- TÁsSIO}

O teor de $\mathbf{K}$ do solo nas condiçós de Votuporanga eram altos (Tabela 1) e, talvez por isso, houve poucas diferenças entre cultivares dentro de doses de potássio para as caracteristicas avaliadas (Figura 1).

HANWAY \& WEBER (1971c) relataram que aplicações moderadas de $\mathbf{K}$ tiveram pouco efeito sobre os pesos das diferentes partes das plantas ou sobre o rendimento de grãos. Quando, porém, se fazia aplicaçóes pesadas de KCl o peso total da massa seca da planta e o rendimento de graos eram significativamente reduzidos. Tal comportamento nå foi observado neste estudo.

As diferenças foram registradas quando se avaliou - efeito de doses de potássio no teor de $\mathbf{N}$ da parte aerea e nos parametros da nodulaçăo. O cultivar IAC-8 apresentou teor de $\mathbf{N}$ da parte aerea superior ao do IAC-14 somente no tratamento $k_{0}$. IAC-8 apresentou maior materia seca de nódulos somente na ausência de potássio ou com a adição de $\mathbf{k}_{1}$ (Figura 1A) mas, seu número de nódulo foi superior ao do 

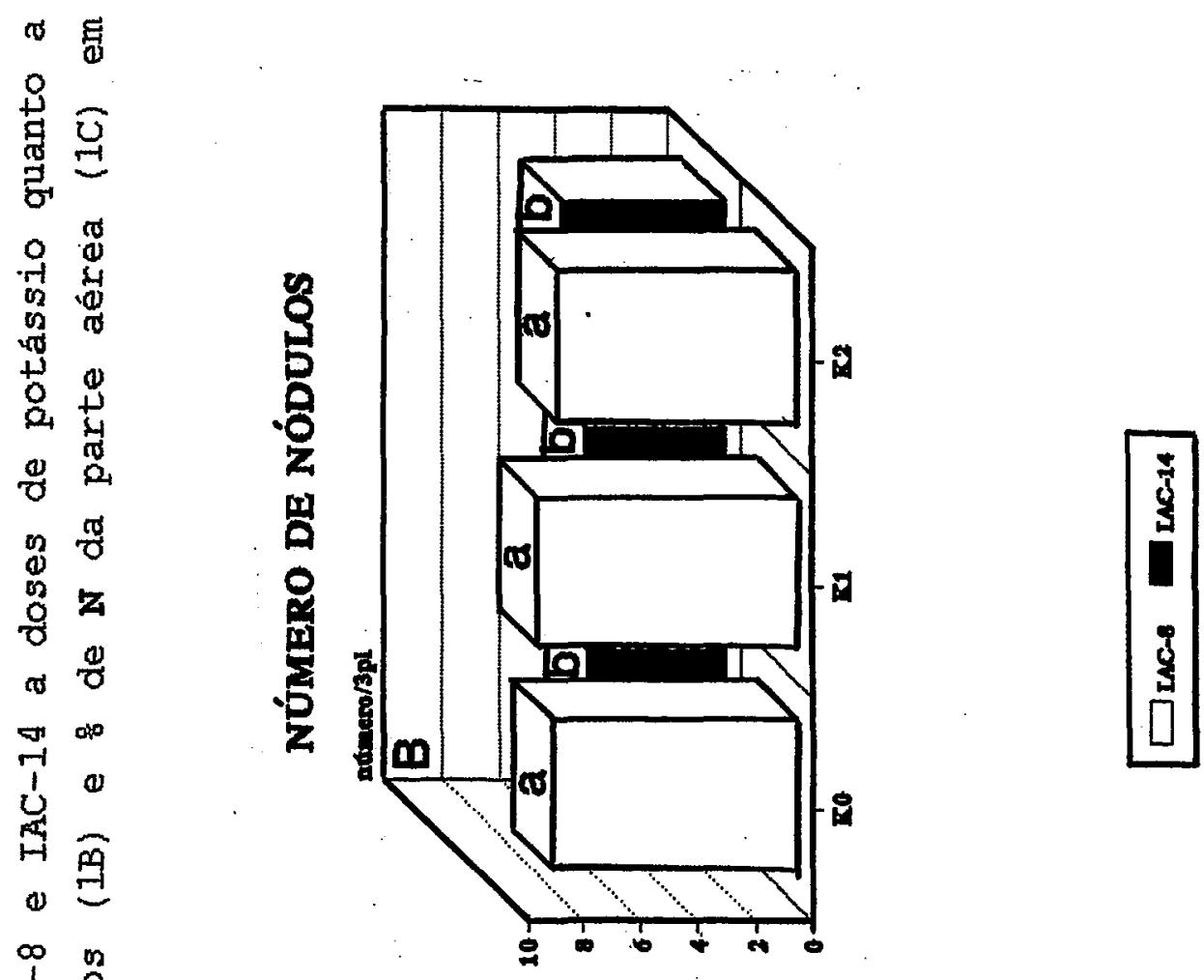

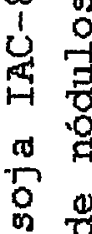

엉

ด

岱

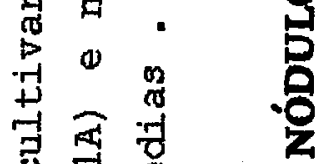
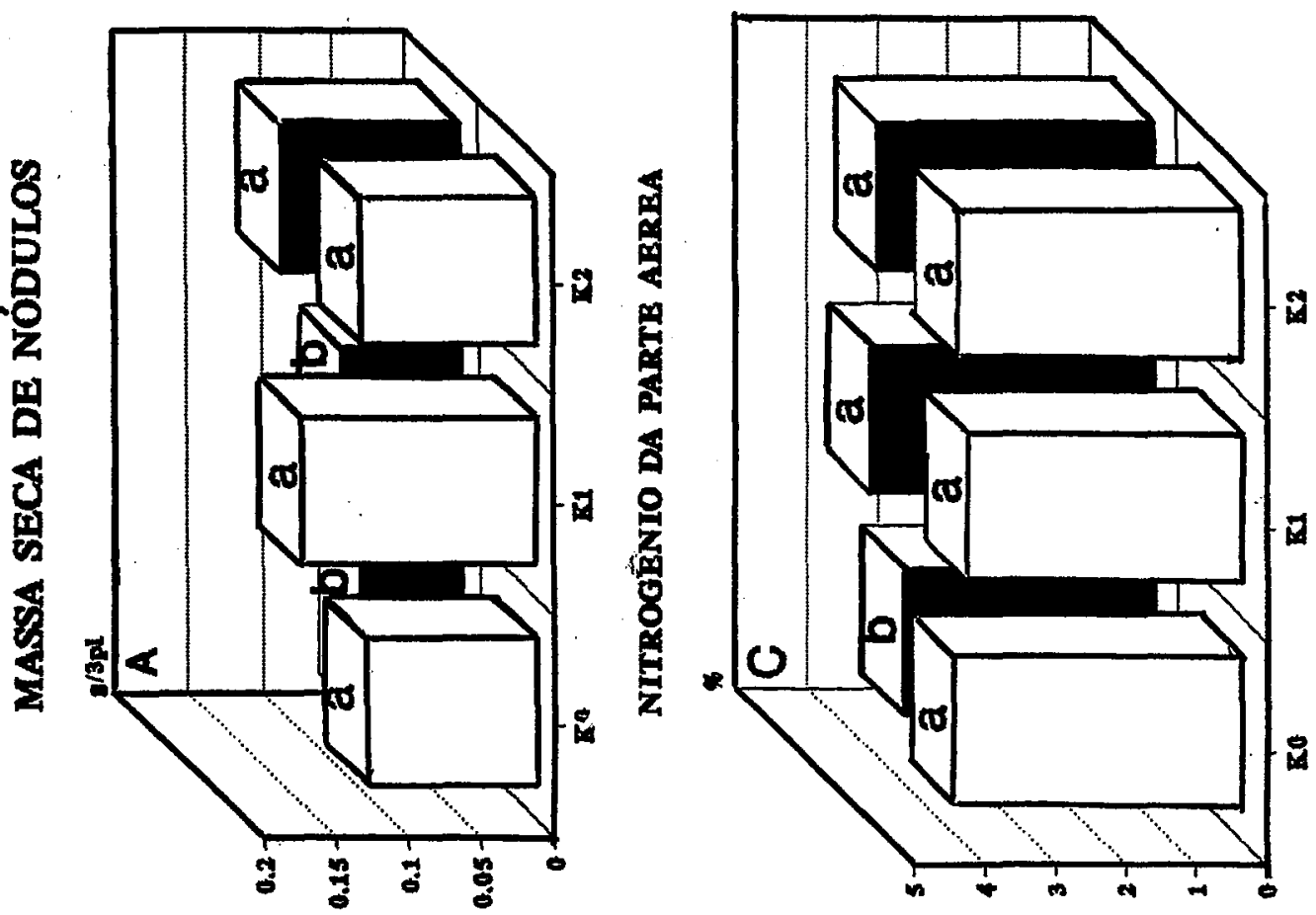

省 
IAC-14 em quaisquer dos tratamentos com potássio (Figura 1B) .

JONES et al. (1977) observaram que aplicaçăo de potássio aumentava o número de nódulos por planta e por unidade de volume de solo, o peso total e individual dos nódulos e o número de vagens por planta. Relataram ainda que o aumento na produção, no número e tamanho de nódulos e na fixaçăo do nitrogeñio nao podiam ser inteiramente atribuídos a tratamentos com potássio o que já havia sido verificado por PERKINS (1924). A adição de potássio, possivelmente, produz plantas mais vigorosas que por sua vez são capazes de nutrir melhor os nódulos.

DUKE \& COLLINS (1985) observaram que o efeito da deficiencia de potássio sobre a nodulação ou sobre a fixação do nitrogenio parece ser indireto. A deficiencia de potássio não é acompanhada por qualquer sintoma de deficiência de N. São geralmente associadas com concentrações de $\mathbf{N}$ na folha ou no grão (ou ambos) iguais ou maiores que aquelas de plantas crescidas com $\mathbf{K}$ suficiente para obter produtividades ótimas.

Quanto ao teor de $\mathbf{N}$ da parte aerea verificou-se que a não adição de potássio beneficiou IAC-8 não havendo diferença entre cultivares nos tratamentos $\mathbf{K}_{\mathbf{1}}$ e $\mathbf{k}_{\mathbf{2}}$ (Figura 1C) indicando que $I A C-14$ é mais exigente em potássio que o IAC-8. DUKE \& COLLINS (1985) verificaram que com o aumento da dose de potássio a concentraça de nitrogenio nos 
tecidos das leguminosas permaneciam relativamente constante e que esse $\mathbf{N}$ acumulava-se como função do acúmulo da matéria seca.

\subsection{EFEITO DE DOSES DE NITROGÊNIO}

\subsubsection{MOCOCA}

A matéria seca da parte aérea, o teor de $\mathbf{N}$ da parte aérea, o número de nódulos e o rendimento de grãos respoderam às doses de $\mathbf{N}$ de acordo com uma equaçåo quadrática (Tabela 16): A dose que esteve relacionada com a produção máxima de cada parametro, exceto quanto ao número de nódulos e produtividade, esteve no intervalo entre 50 e $61,5 \mathrm{~kg} / \mathrm{ha}$ de $\mathbf{N}$ (Tabela 16). O maior número de nódulos e 0 maior rendimento de grăos seriam obtidos, respectivamente com $28,05 \mathrm{~kg} / \mathrm{ha}$ e $70,51 \mathrm{~kg} / \mathrm{ha}$ de $\mathbf{N}$.

Nesse experimento, observou-se que aplicaçoses de doses crescentes de uréia resultaram em acúmulo no teor de $\mathbf{N}$ da parte aérea atingindo-se um máximo de 3,59 웅 de $\mathrm{N}$ com a dose de $61,48 \mathrm{~kg} / \mathrm{ha}$ de $\mathbf{N}$. O teor mais baixo de $\mathbf{N}$ da parte aerea obtido no tratamento onde nao foi aplicado $\mathbf{N}$ demonstra que a fixaçăo simbiótica nå foi capaz de suprir a planta adequadamente (Figura 2A) . O acúmulo de $\mathbf{N}$ no gräo, foi linearmente aumentado com $O$ aumento da dose de $\mathbf{N}$ (Figura 2B). 


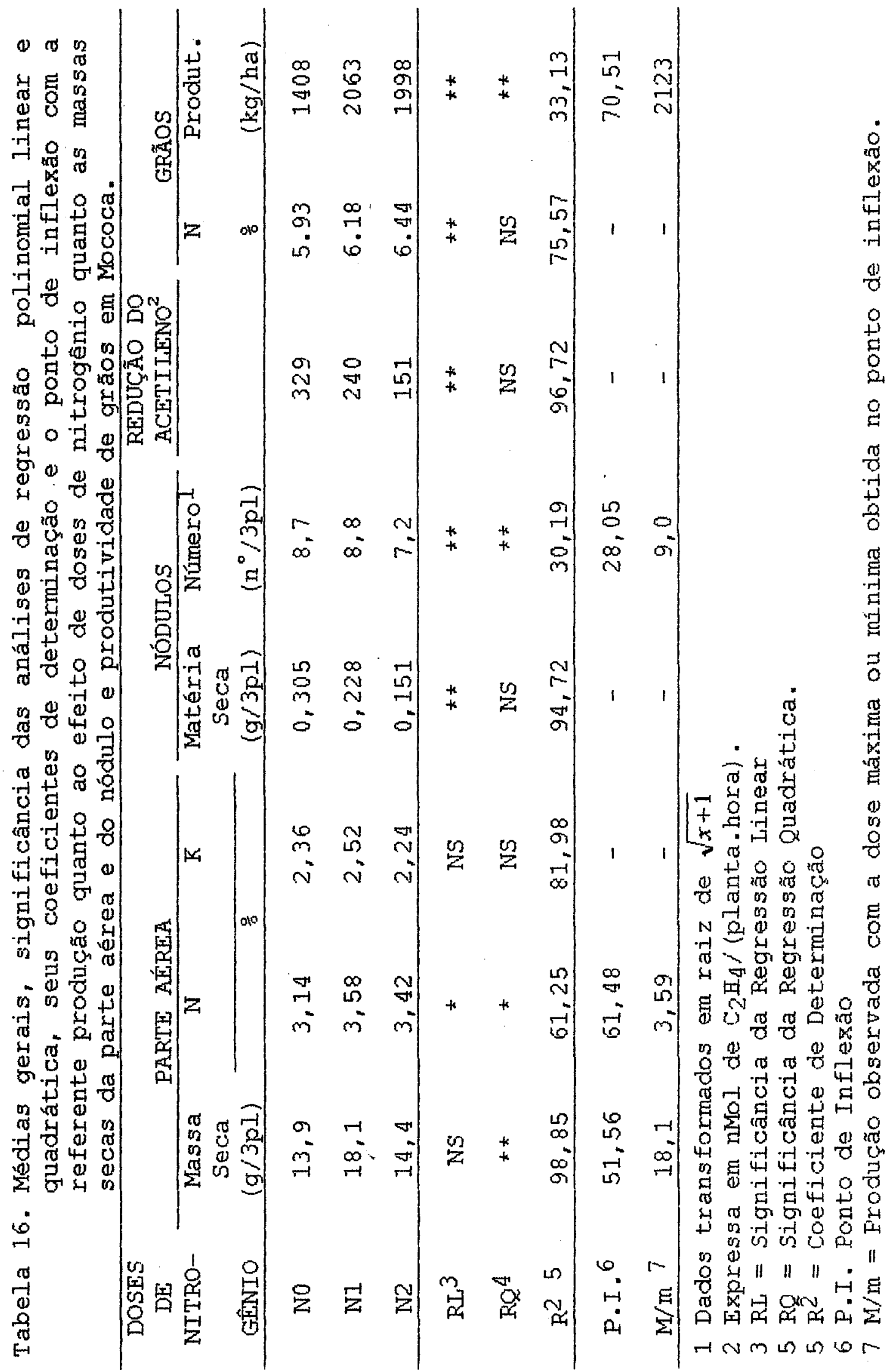




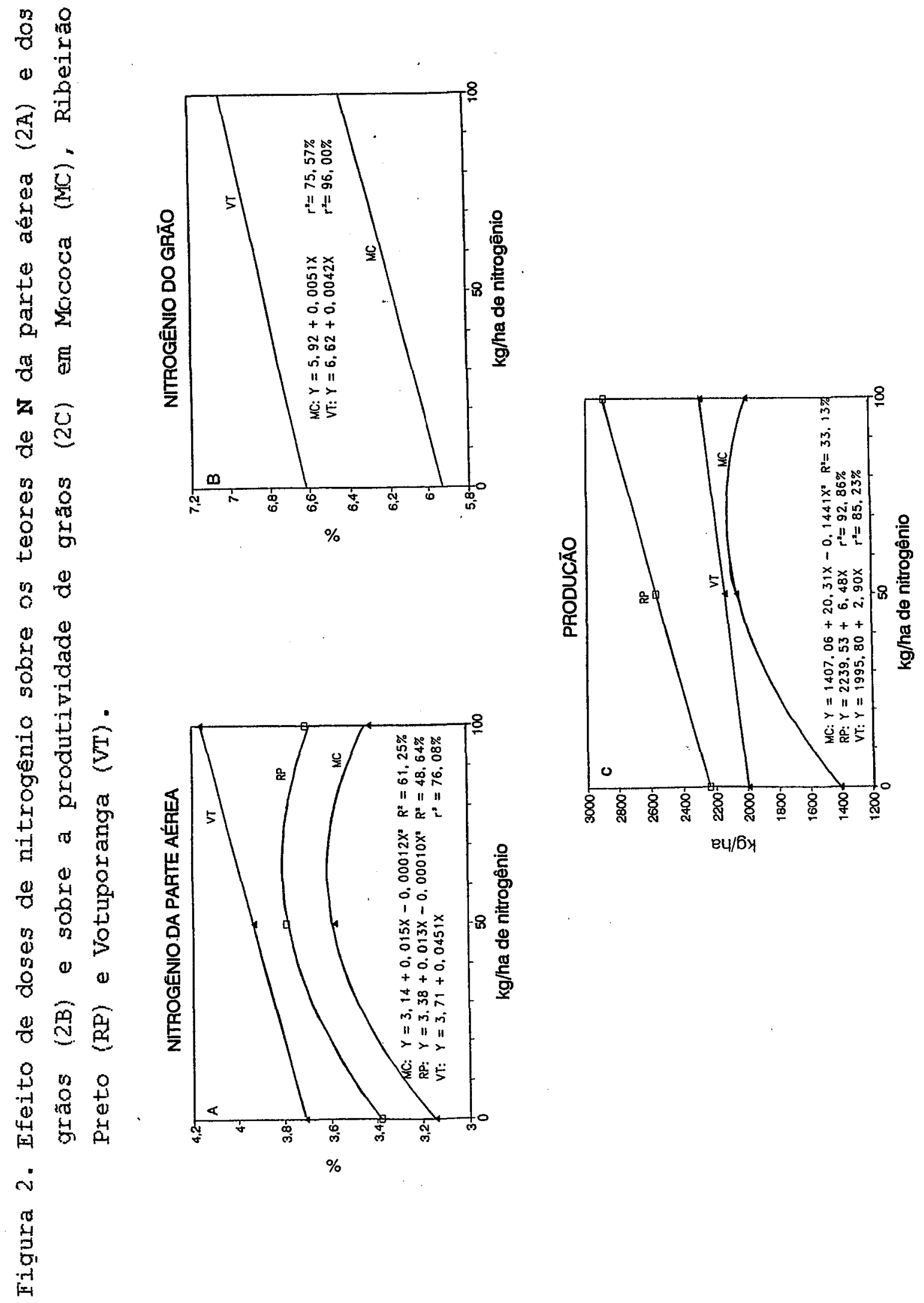


- rendimento de grãos aumentou ate a dose de $70,51 \mathrm{~kg} / \mathrm{ha}$ de $\mathbf{N}$ sendo calculado que neste caso este seria de $2123 \mathrm{~kg} / \mathrm{ha}$ (Figura 2C). A diferença estimada na produtividade de grãos entre a não aplicação de $N$ e a adição de $70,47 \mathrm{~kg} / \mathrm{ha}$ foi de $316 \mathrm{~kg} / \mathrm{ha}$ correspondendo a 33,78 .

De acordo com OHLROGGE (1960), o rendimento de grãos de soja está intimamente correlacionado com a quantidade de $\mathbf{N}$ acumulada pela planta durante seu ciclo. Observando-se as doses de $\mathbf{N}$ nas quais se obteve os maiores teores de $\mathbf{N}$ da parte aérea, verificou-se que este está próximo daquele em que se obteve produção máxima. TANAKA (1985) verificou que a adição de adubo nitrogenado aumentaria a disponibilidade desse elemento e, sendo absorvido pelas plantas acarretaria maior acúmulo de $\mathbf{N}$ no grão com reflexos na produção.

Esse aumento expressivo obtido no rendimento de gráos com o aumento da dose de $\mathbf{N}$ indica que nas condiçôs de inverno, para maximizar a produtividade, e conveniente adicionar nitrogenio. Como a produtividade respondeu ao suprimento de $\mathbf{N}_{1}$ é provável que as estirpes do inoculante comercial e as prováveis existentes na área năo foram capazes de suprir a planta com quantidades de $\mathbf{N}$ suficiente.

A massa seca e a atividade total dos nódulos diminuiram linearmente com 0 aumento da dose de N. mas, 
estimou-se que o número de nódulos aumentaria até a adição de $28,05 \mathrm{~kg} / \mathrm{ha}$ de N (Tabela 16).

\subsubsection{DOSES DE NITROGENIO DENTRO DE CUL- TIVAR}

Poucos caracteres agronômicos responderam a doses de nitrogenio. Houve interaçăo entre doses de $\mathbf{N}$ dentro de cultivares para teor de $\mathbf{K}$ da parte aerea (Tabela 17).

No cultivar IAC-8, houve diminuiçăo linear no acúmulo de $\mathbf{K}$ da parte aérea com o aumento da close de N.O cultivar IAC-14, ao contrário, respondeu positivamente à adição de $\mathbf{N}$ até a dose de $54,62 \mathrm{~kg} / \mathrm{ha}$ indicando metabolismo sensivel a condiçoes nutricionais ideais (Tabela 17).

As doses de nitrogenio afetaram os cultivares quanto a nodulação. As massas secas dos nódulos e a atividade total dos nódulos para ambos os cultivares foram linearmente reduzidas com o aumento da dose de $\mathbf{N}$ (Tabela 18). O número de nódulos, entretanto, foi reduzido linearmente com o aumento da dose de $\mathbf{N}$ no cultivar IAC-14. No IAC-8 houve redução no numero ate a dose de $31,55 \mathrm{~kg} / \mathrm{ha}$ (Tabela 18).

WATERER \& VESSEY (1993) demonstraram que, embora - nitrogenio seja particularmente inibitório ao crescimento do nódulo e à atividade da nitrogenase é menos prejudicial ao processo de infecção. 


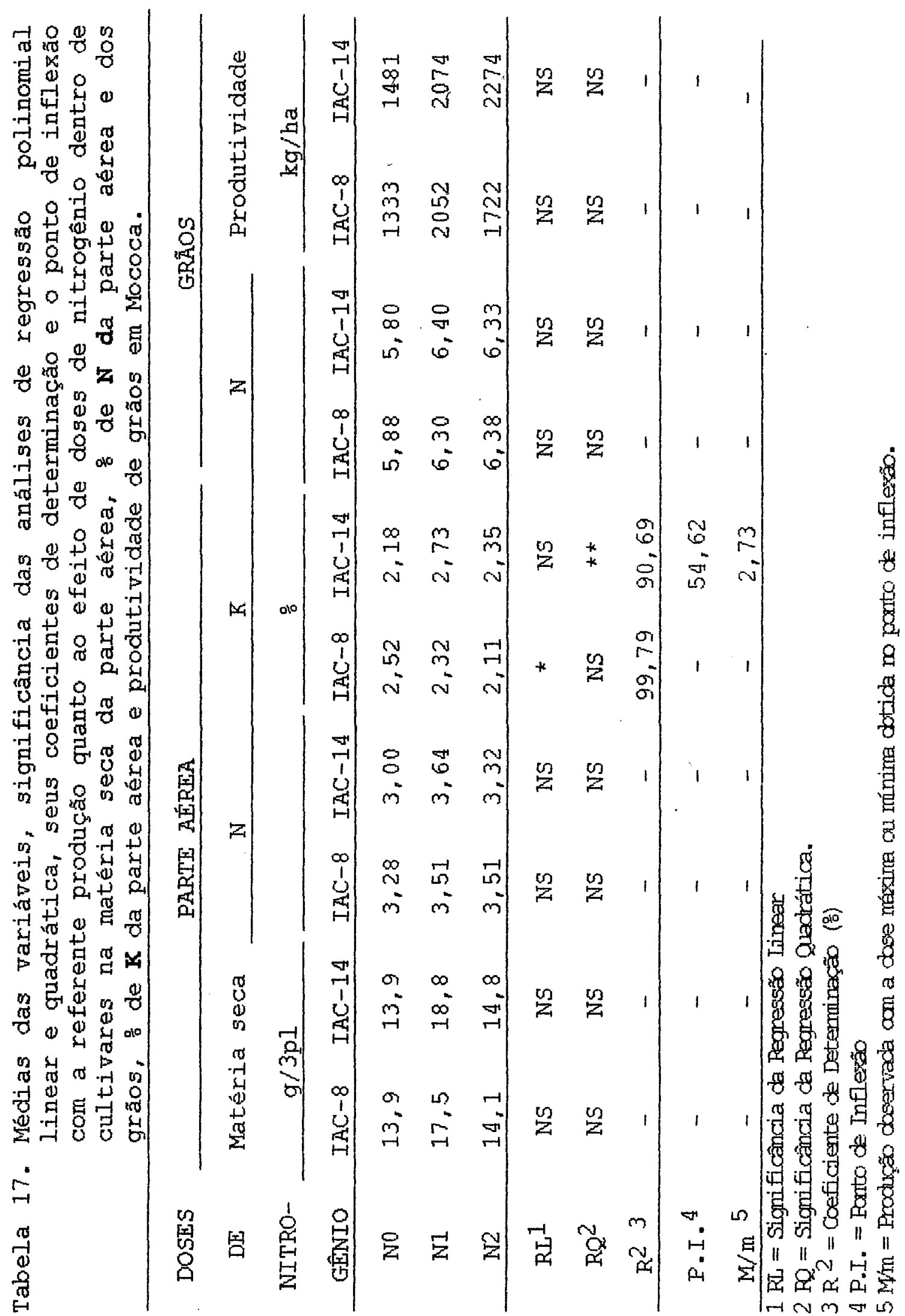




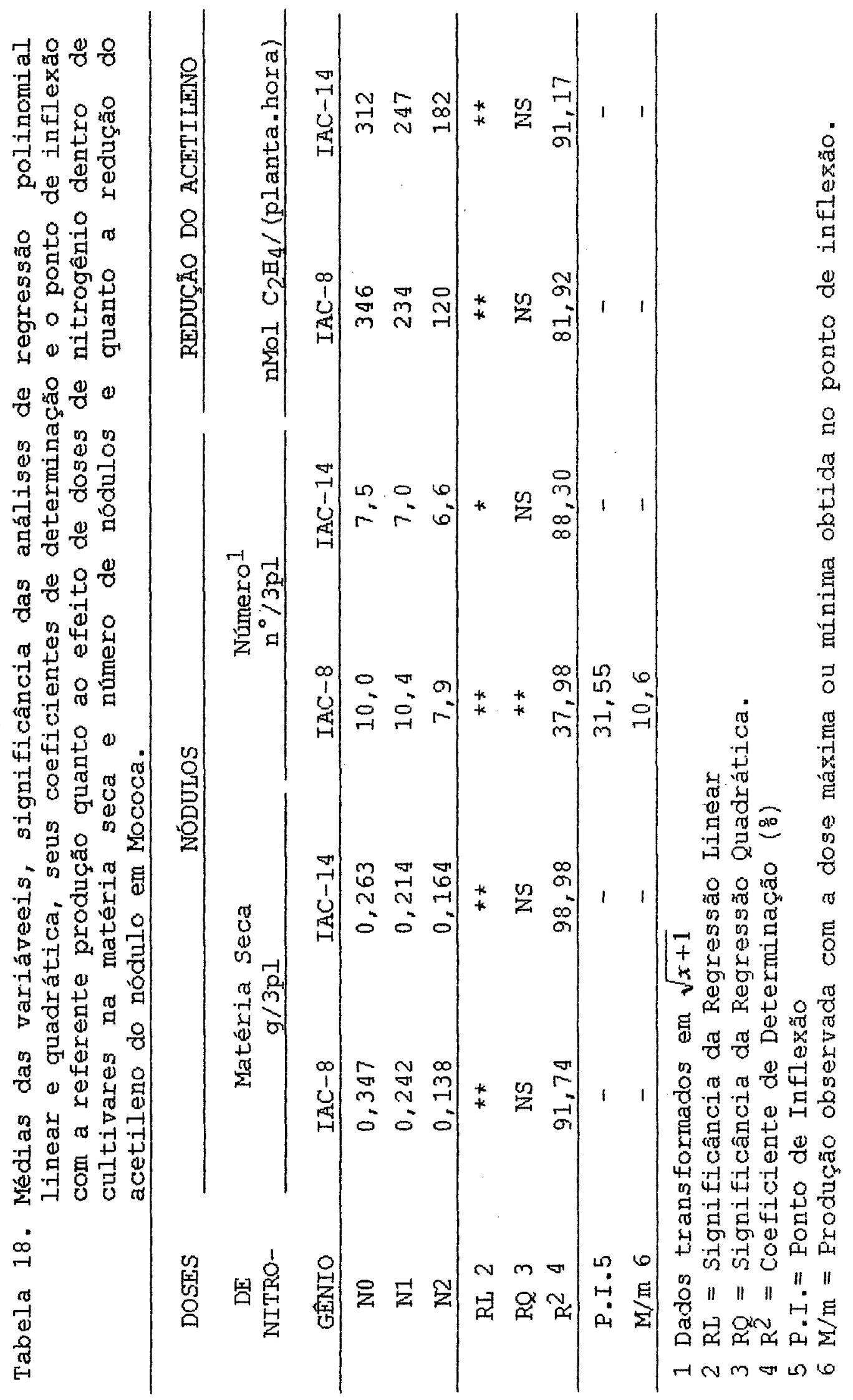


- grau de inibição da nodulação é dependente da concentração de $\mathbf{N}$ e, varia com os cultivares. Se a concentração exceder a determinados valores, pode reduzir o número final de nódulos e até acarretar a completa supressão da nodulação. HINSON (1975) constatou que o efeito do nitrogenio pode ser manifestado no desenvolvimento do nódulo de maneira que, o número permaneça inalterado mas, a matéria seca por planta é reduzida por afetar o seu desenvolvimento.

\subsubsection{DOSES DE NITROGÊNIO DENTRO DE DOSES DE POTÁSSIO}

A interação de doses de $\mathbf{N}$ dentro de doses de $\mathbf{K}$ são apresentadas nas Tabelas 19 e 20. Observou-se que a materia seca da parte aérea com quaisquer das doses de potássio aplicadas respondeu positivamente ao aumento de dose de $\mathbf{N}$ segundo uma equaçăo quadratica (Tabela 19). Na dose $\mathbf{k}_{0}$, a materia seca da parte aérea aumentou, até a dose de $53,80 \mathrm{~kg} / \mathrm{ha}$ de nitrogenio. Quando foi adicionado $\mathbf{k}_{1}$, estimou-se que houve aumento na materia seca da parte aerea até a aplicaçăo até $55,27 \mathrm{~kg} / \mathrm{ha}$ de $\mathbf{N}$. Já com a adição de $\mathbf{K}_{2}$ houve respostacrescente com a aplicaçăo de $42,98 \mathrm{~kg} / \mathrm{ha}$ de $\mathbf{N}$ para a parte aerea.

Nå houve interaça entre doses de nitrogenio dentro de doses de potássio nos teores de $\mathbf{N}$ da parte aerea 


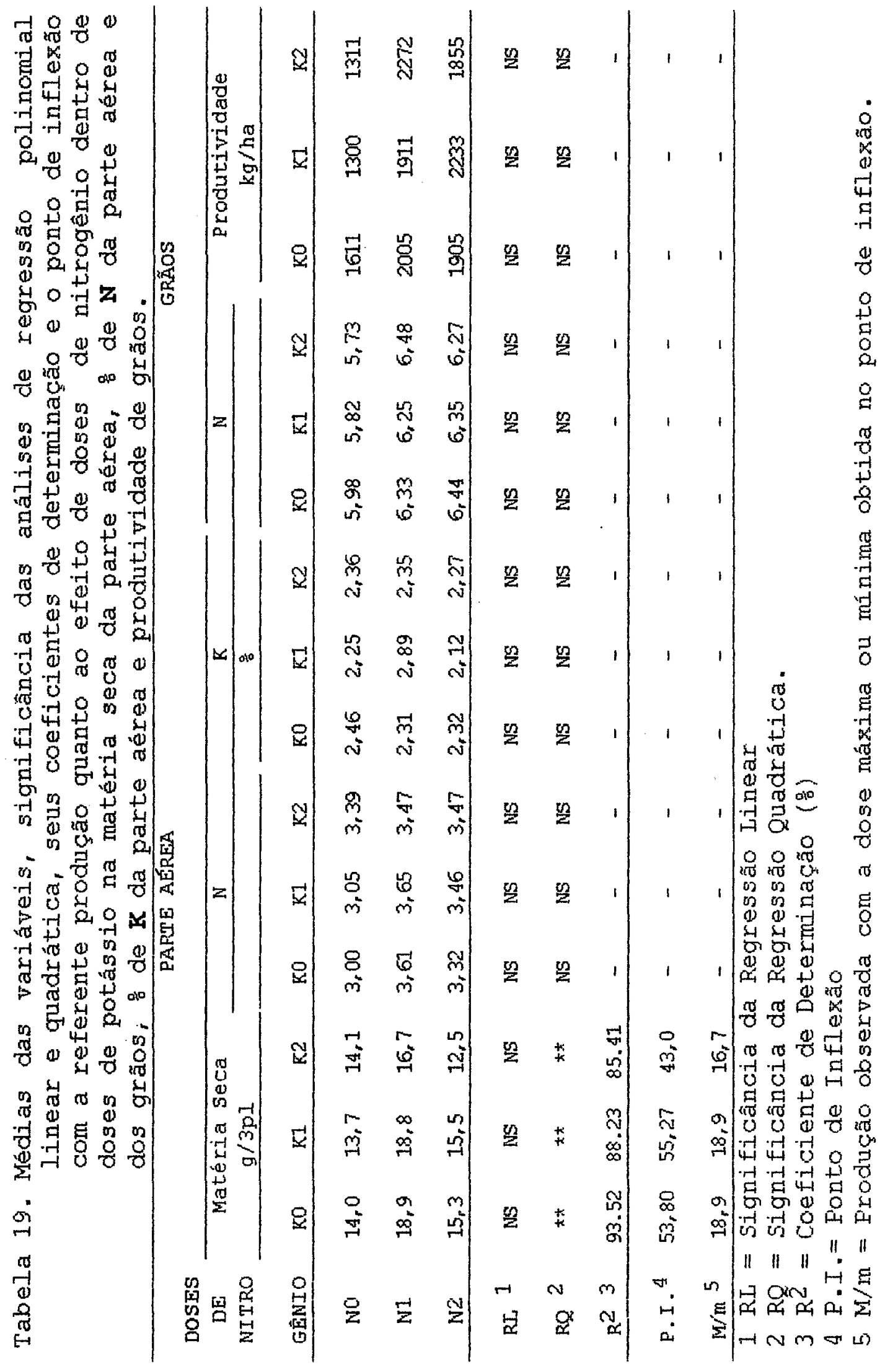




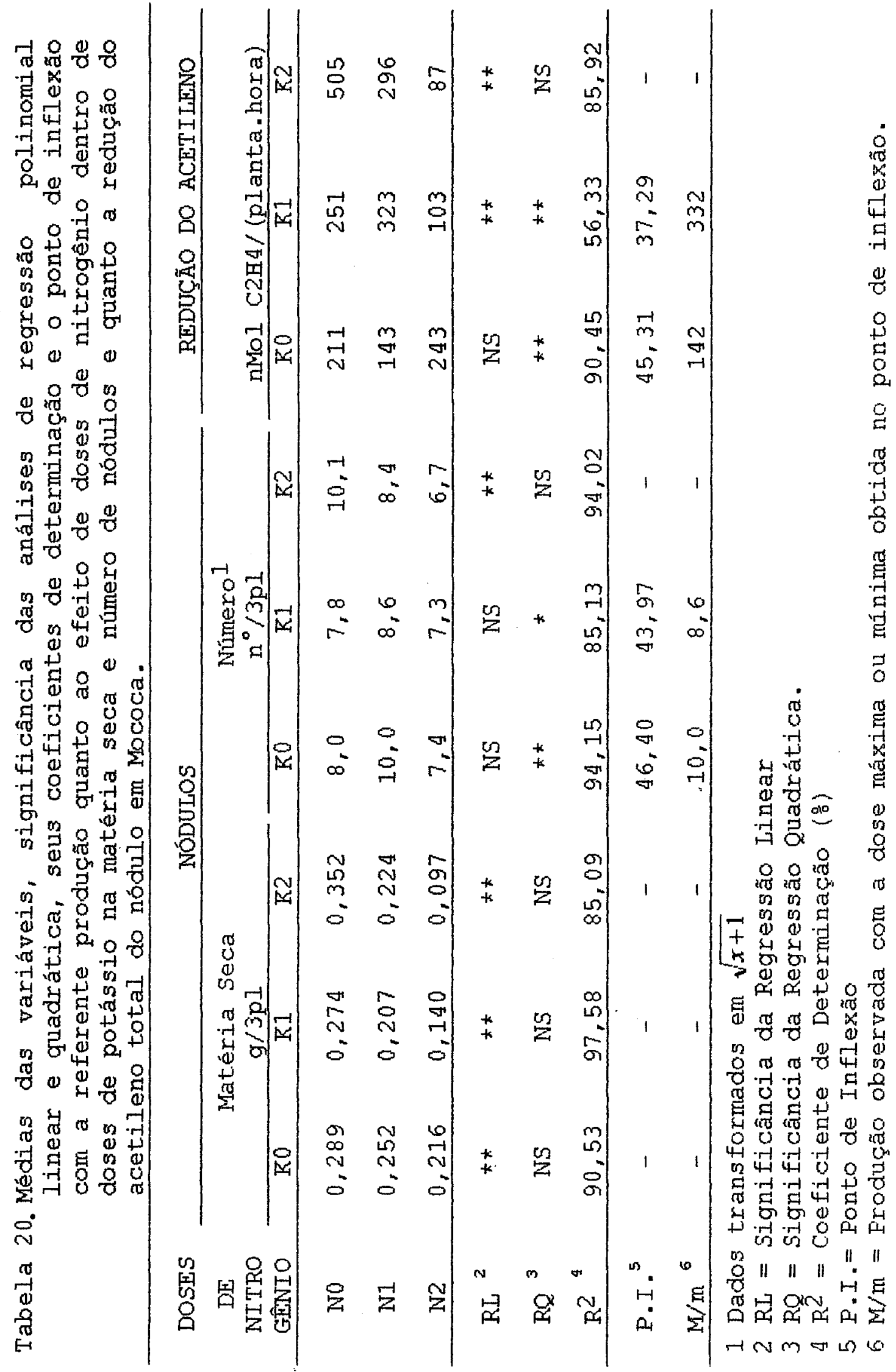


e dos grãos, no teor de potássio da parte aérea e na produtividade de grăos (Tabela 19).

- potássio não afetou a matéria seca de nodulos que, foi linearmente reduzida com o aumento da dose de nitrogênio (Tabela 20). O número de nódulos, entretanto, com a aplicação de $\mathbf{k}_{1}$ e sem $\mathbf{k}$ foram aumentados até as doses respectivas de 46,40 e $43,97 \mathrm{~kg} / \mathrm{ha}$ de $\mathrm{N}$. Porem, quando foi adicionado $\mathbf{k}_{\mathbf{2}}$, o aumento da close de $\mathbf{N}$ reduziu linearmente os valores daquele parâmetro (Tabela 20).

Nos tratamentos sem $\mathbf{k}$, verificou-se que houve redução na atividade total do nódulo sendo obtido uma atividade mínima com a adição de $45,31 \mathrm{~kg} / \mathrm{ha}$ (Tabela 20 ). Quando se adicionou $\mathbf{K}_{1}$, foi observado que a atividade aumentou com a adição de $\mathbf{N}$ atingindo seu ponto máximo com a adição de $37,29 \mathrm{~kg} / \mathrm{ha}$ de $\mathbf{N}$. A adição de $\mathbf{K}_{2}$ provocou redução linear com o aumento da dose de nitrogênio na atividade total do nódulo.

WATERER et al.(1992) relataram que plantas supridas com nitrogênio, têm taxas de crescimento mais rápida do que as sem esse elemento devido ao seu acesso imediato ao nutriente. Deve-se porém, considerar que as mudanças na temperatura podem ter exercido influência na absorção do nitrogênio mineral afetando a taxa de crescimento da planta e a relação entre a parte aérea e raizes afetando a absorção desse elemento por unidade da raiz (HATCH \& MACDUFE, 1991). 
Os resultados sugerem que a interação entre os dois elementos contribui apenas para um melhor desenvolvimento da planta, em tamanho. Na nodulação, os efeitos foram, na maioria dos parâmetros, depressivos.

\subsubsection{RIBEIRÃO PRETO}

Na Tabela 21 sao apresentadas os efeitos de doses de $\mathbf{N}$ sobre os diferentes parametros analisados. Esses dados mostram que năo houve efeito de doses de $\mathbf{N}$ na materia seca da parte aerea.

A Figura 2A mostra que embora a regressao quadrática seja significativa para 8 de $\mathbf{N}$ da parte aerea, seu coeficiente de determinaçăo foi baixo $(48,648)$ mostrando que a equação de 20 grau nao deu bom ajuste para esse parametro. Estimou-se que houve acúmulo de $\mathbf{N}$ na parte aerea até a dose de $64,83 \mathrm{~kg} / \mathrm{ha}$ de $\mathrm{N}$ e depois ocorreu ligeiro decréscimo. ALLOS \& BARTHOLOMEW (1959) também observaram a influencia de doses crescentes de $\mathbf{N}$ inorganico sobre a absorçăo de $\mathbf{N}$. O teor de $\mathbf{N}$ da parte aerea foram superiores aos encontrados por HAMMOND. (1949) durante 0 florescimento os quais variaram de 2,5 a 2,98 .

Com relaçăo ao teor de $\mathbf{K}$ da parte aerea, verificou-se reduçăo desse parametro com o aumento da dose de $\mathrm{N}$, sendo estimado um valor mínimo de $2,348 \mathrm{com}$ adição de $43,64 \mathrm{~kg} / \mathrm{ha}$ de $\mathrm{N}$. 


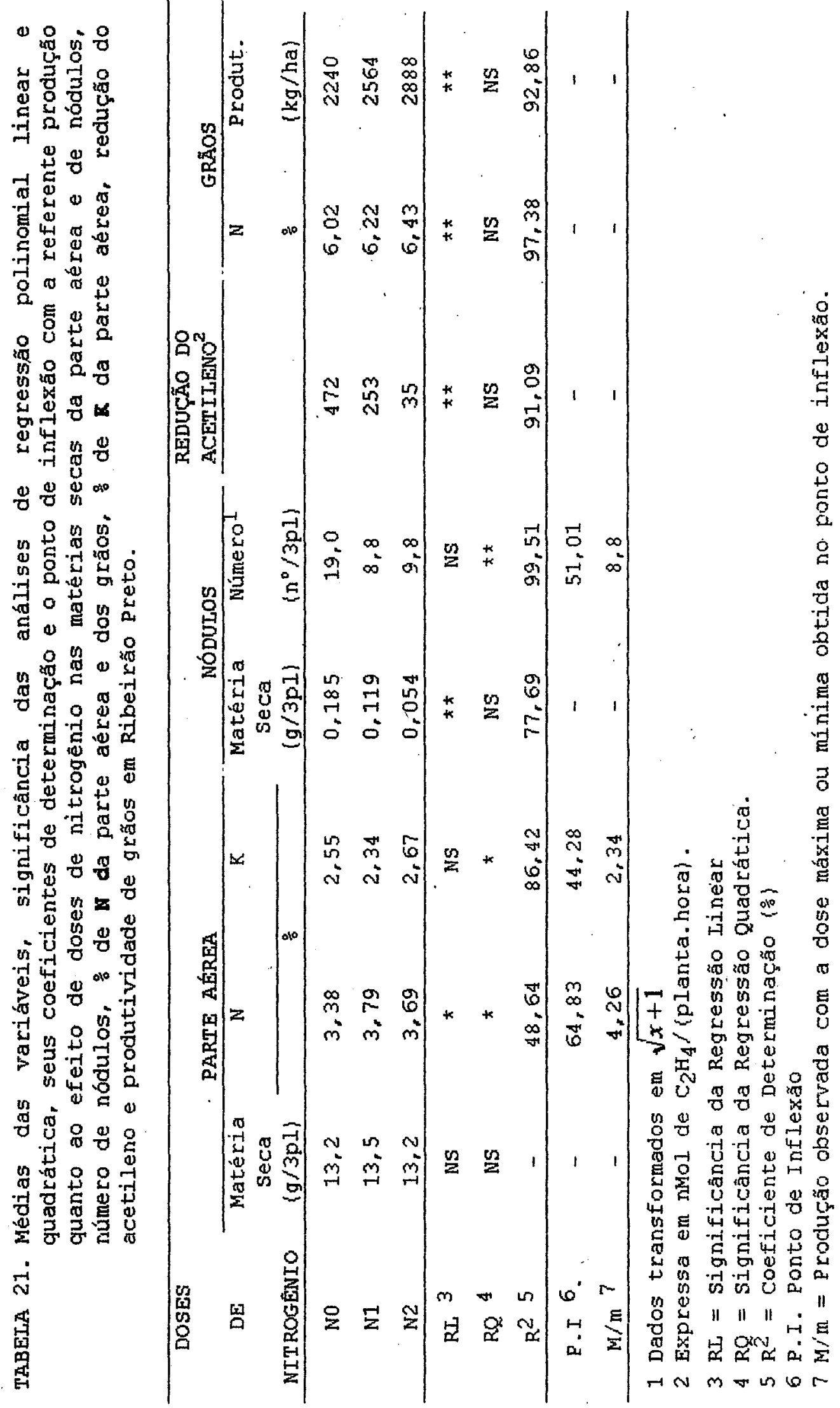


O efeito de $\mathbf{N}$ na matéria seca dos nodulos e na atividade total dos nódulos foi linear e inversamente correlacionado com a dose de $N$ aplicado. KANAYAMA \& YAMAMOTO (1990) verificaram que a diminuição na atividade da nitrogenase em nódulos de soja suplementados com nitrogênio é causada pela diminuição no nível de oxileghemoglobina carregador do oxigênio para o bacteróide resultando na formação de nitroseleghemoglobina.

O aumento nas doses de $\mathbf{N}$ causou redução no número de nódulos, sendo estimado que com 51,01 $\mathrm{kg} / \mathrm{ha}$ de $\mathrm{N}$ seria alcançado o nível mínimo.

Em relação ao teor de $\mathbf{N}$ do grão e à produtividade de sementes verificou-se que houve efeito linear positivo com o aumento da dose de $\mathbf{N}$ (Eiguras $2 \mathrm{~B}$ e 2C). TANAKA \& MASCARENHAS (1992) recomendam que seja adicionado à soja de inverno $50 \mathrm{~kg} / \mathrm{ha}$ de $\mathbf{N}$. Adicionando-se essa quantidade de $\mathbf{N}$ à soja cultivada nas condições de Ribeirão preto haveria um acréscimo na produção de 324 $\mathrm{kg} / \mathrm{ha}$ de grãos em relação ao tratamento sem $\mathbf{N}$ e inoculado.

\subsection{2:1. DOSES DE NITROGENIO DENTRO DE CUL- TIVAR}

Pelos dados da Tabela 22 verificou-se que nao houve efeito de doses de $\mathbf{N}$ dentro de culẗivares em nenhum dos parâmetros agronómicos estudados. 


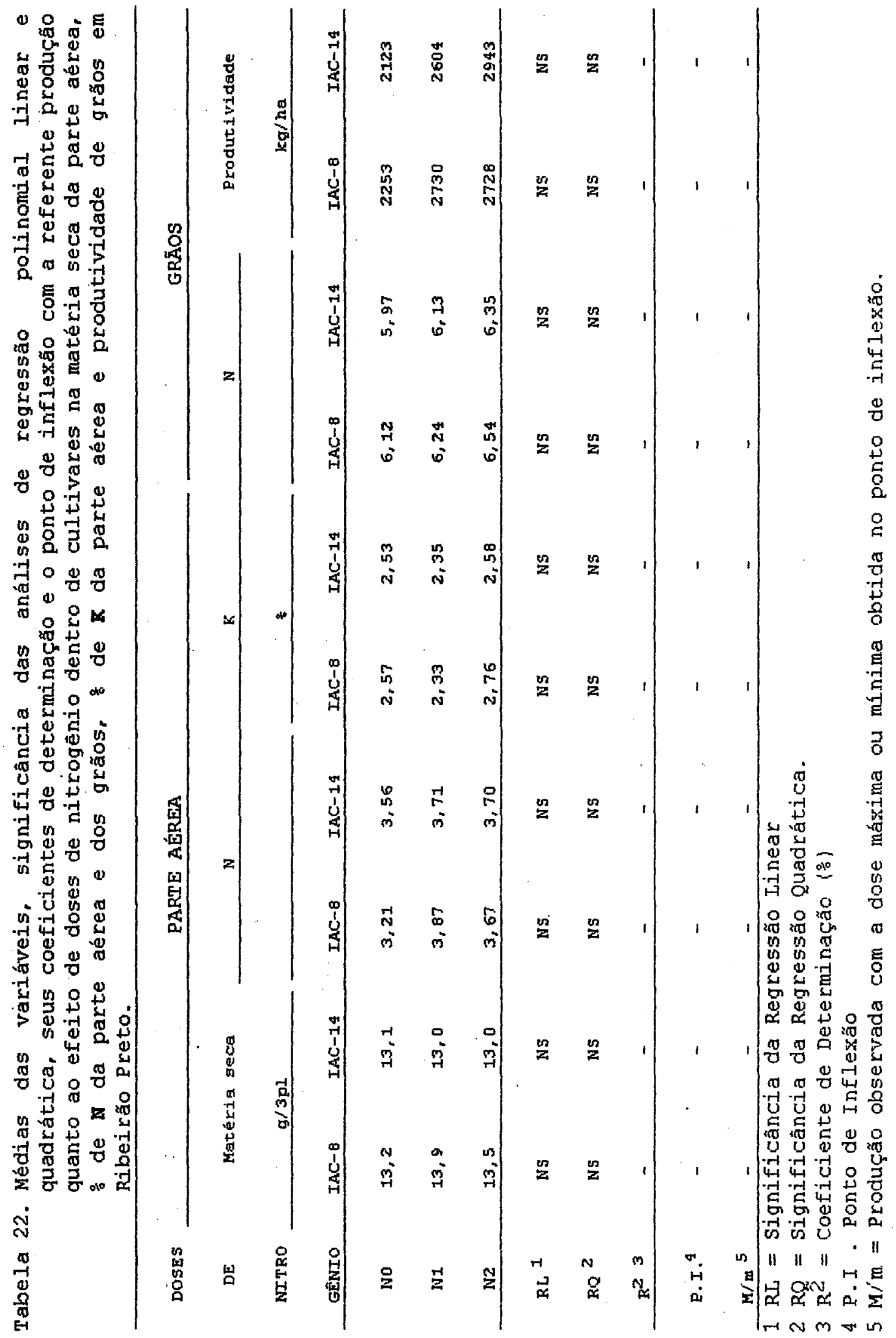


Pelos dados da Tabela 23 verificou-se que a resposta da matéria seca de nódulos do cultivar IAC-14 e da atividade total dos nódulos de ambos os cultivares foi linear e inversamente relacionada com a dose aplicada. A matéria seca de nódulos do cultivar IAC-8 foi reduzida com - aumento do $\mathbf{N}$ adicionado sendo estimado que com a adição de $71,69 \mathrm{~kg} / \mathrm{ha}$ de $\mathrm{N}$ seria obtida a menor massa.

\subsubsection{DOSES DE NITROGÊNIO DENTRO DE DOSES DE POTÁSSIO}

Nas Tabelas 24 e 25 pode-se observar o efeito de dose de nitrogenio dentro de doses de $\mathbf{k}$ nos diferentes parametros.

A produça da materia seca da parte aerea aumentou linearmente quando nå foi aplicado $\mathbf{k}_{0} e$, com a adição de $\mathbf{K}_{2}$, ocorreu aumento até a adição de $46,92 \mathrm{~kg} / \mathrm{ha}$ de $\mathbf{N}$ (Tabela 24). Os outros parametros nåo mostraram diferença estatística devido a interação de $\mathbf{N}$ dentro de doses de potássio.

O aumento da dose do $\mathbf{N}$ aplicado, tanto na presença como na ausencia de $\mathbf{k}$, fez com que a massa nodular fosse reduzida (Tabela 25). Quando se aplicou $\mathbf{K}_{1}$ e $\mathbf{K}_{\mathbf{2}}$, 0 aumento da dose de $\mathbf{N}$ reduziu linearmente a massa nodular. A nåo aplicação de $\mathbf{K}$ fez com que houvesse redução na massa nodular até a aplicaçăo de $66,31 \mathrm{~kg} / \mathrm{ha}$ de $\mathbf{N}$ e, a partir de 


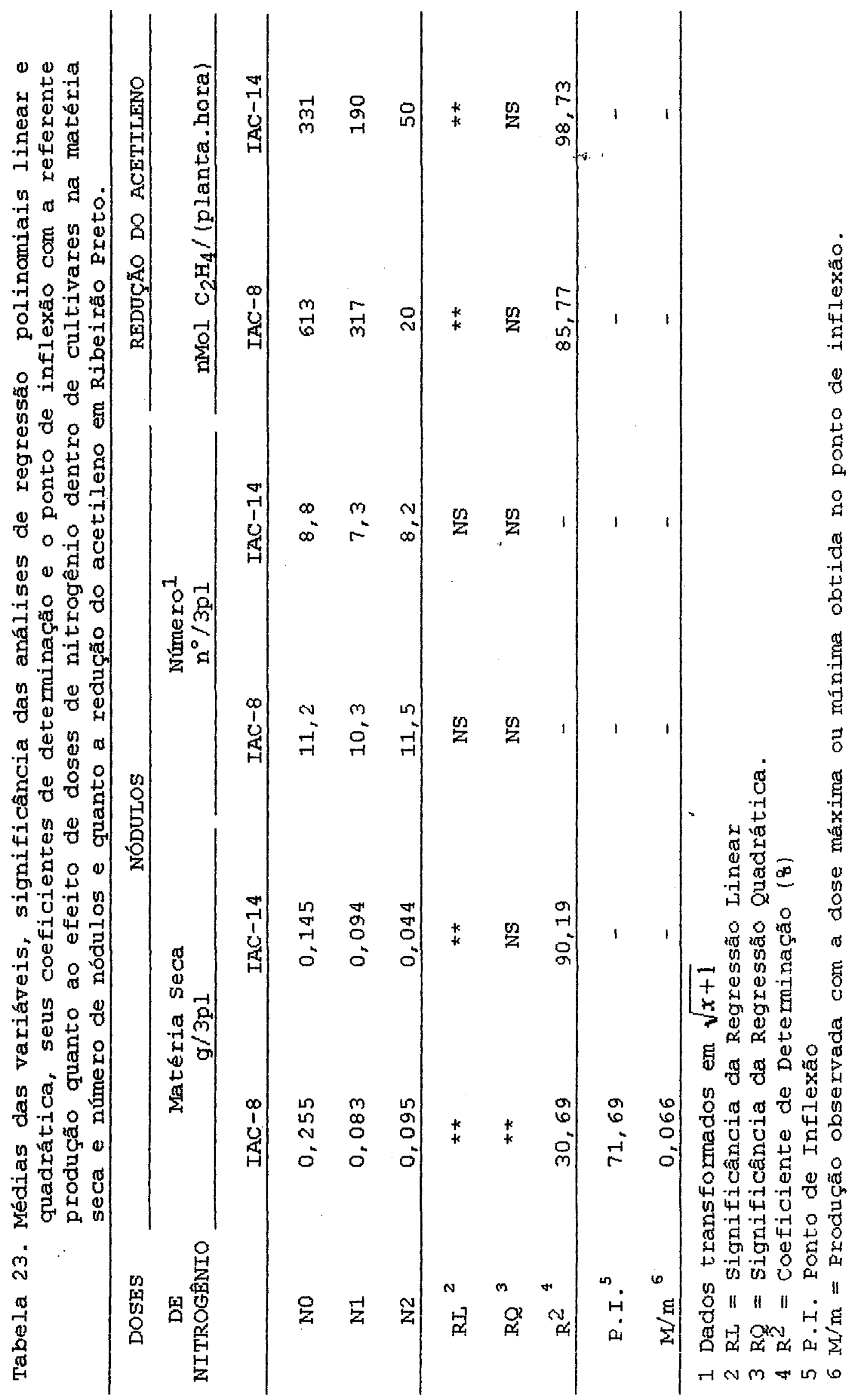




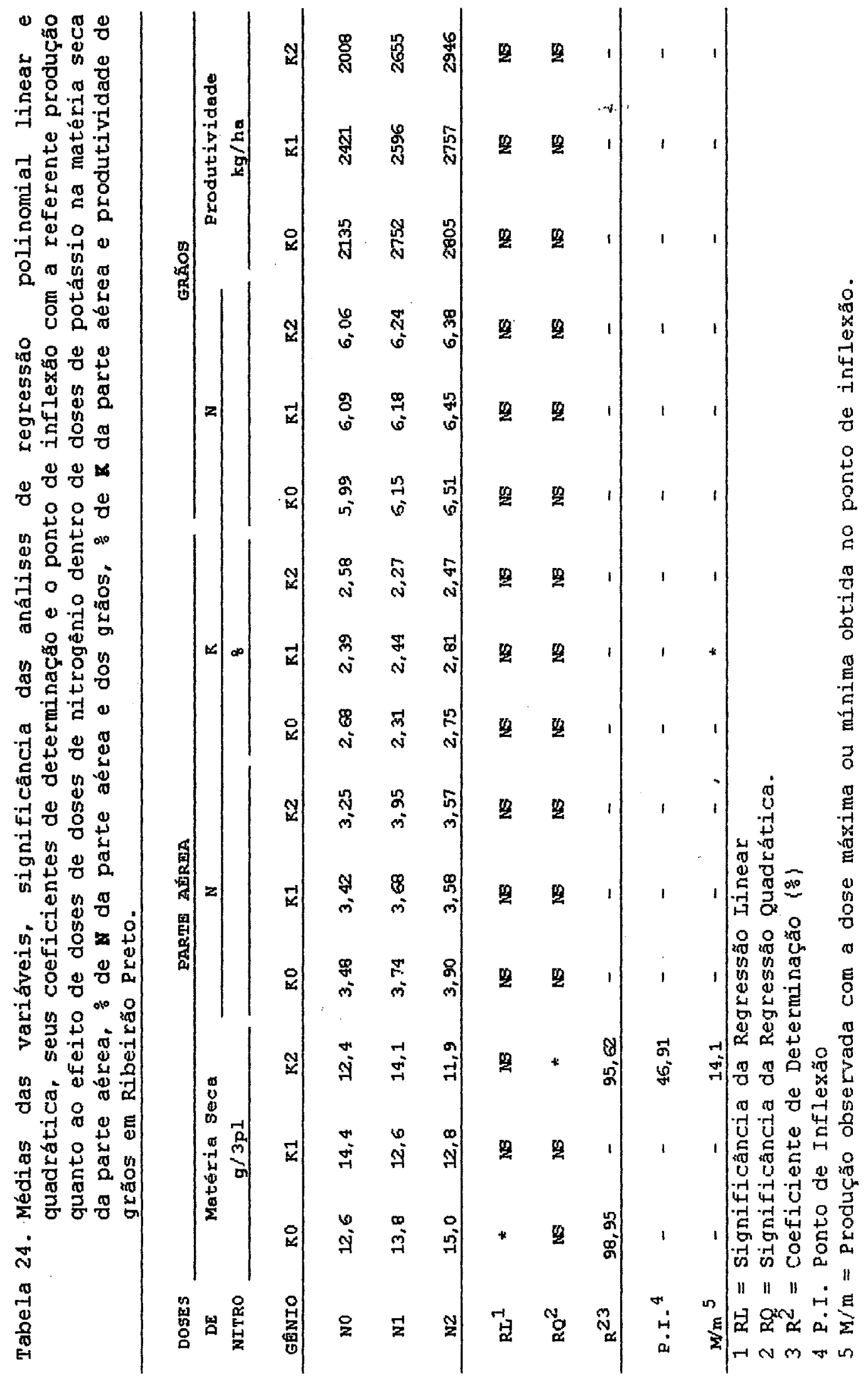




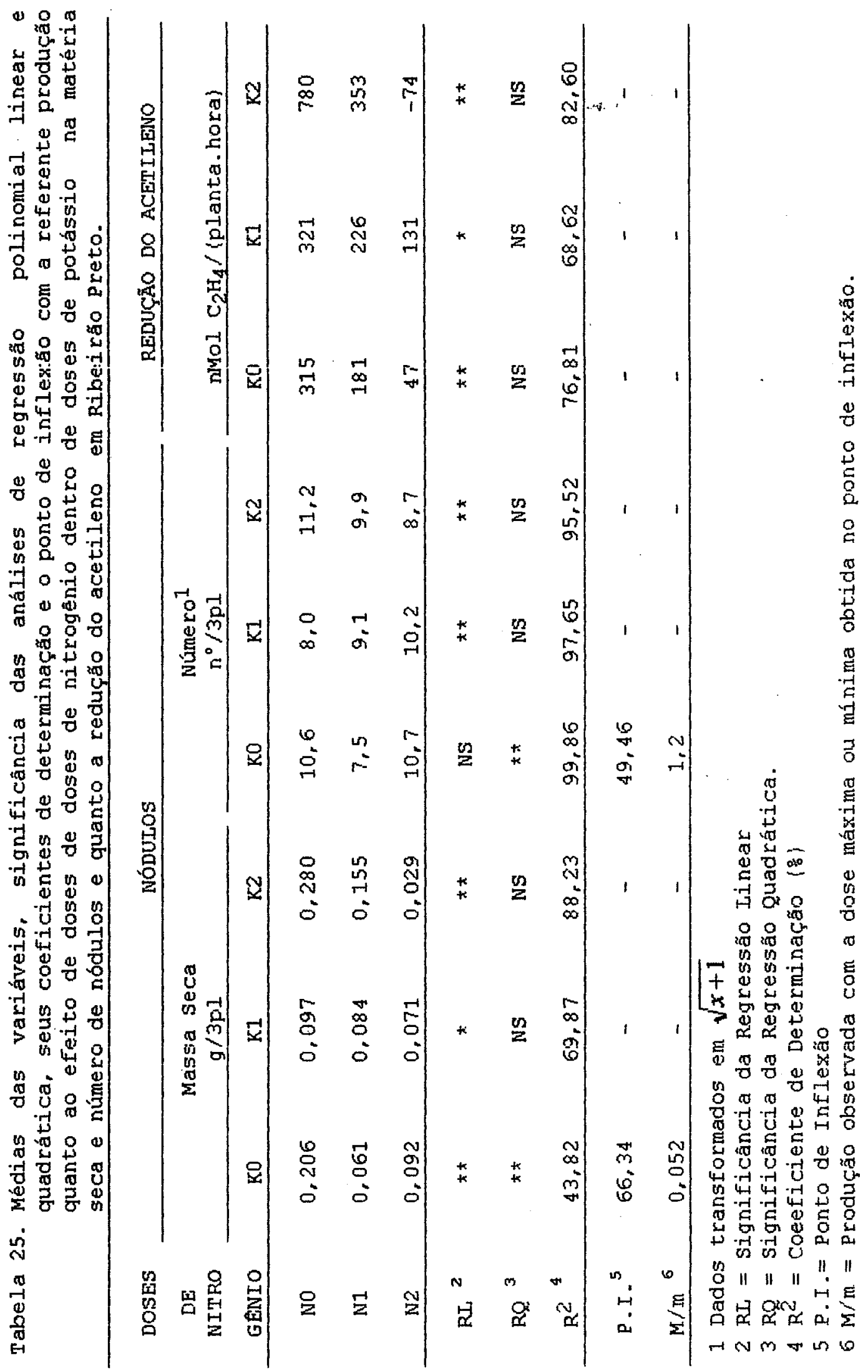


então, um ligeiro aumento (Tabela 25) .

Embora BEARD \& HOOVER (1971) tenham relatado que há relação inversa entre o número de nódulo e a dose de $\mathbf{N}$ aplicada, foi observado que quando nåo foi aplicado $\mathbf{k}$ ocorria diminuição até a aplicação de $49,46 \mathrm{~kg} / \mathrm{ha}$ de $\mathbf{N}$. Quando se aplicava $\mathbf{K}_{\mathbf{1}}$ ocorria aumento linear no número de nódulos; somente quando se aplicou $\mathbf{K}_{\mathbf{2}}$ é que se observou redução linear com o aumento da dose de $\mathbf{N}$ (Tabela 25).

A atividade total do nódulo(Tabela 25), com quaisquer das doses de $\mathbf{K}$ aplicadas foi reduzida linearmente com o aumento da dose de $\mathbf{N}$ o que já havia sido relatado por VERNETTI (1983).

\subsubsection{VOTUPORANGA}

Nas condiçres de votuporanga, verifĩcou-se que só naro houve efeito de doses de $\mathbf{N}$ no teor de $\mathbf{K}$ da parte aérea (Tabela 26). A materia seca da parte aérea foi aumentada pela adição de $\mathbf{N}$, sendo estimado que sua produção máxima seria obtida, com a adiçăo de $39,67 \mathrm{~kg} / \mathrm{ha}$ de $\mathbf{N}$.

Com relaçăo ao teores de $\mathbf{N}_{\lambda}$ da parte aérea e do grăo "e a produtividade de graos ocorreu aumento linear com a adição de $\mathbf{N}$ (Figuras de $2 \mathrm{~A}$ a $2 \mathrm{C}$ ).

os teores de $\mathbf{N}$ no grao foram elevados conseguindo-se com a adição de $100 \mathrm{~kg} / \mathrm{ha}$ de $\mathbf{N}$ acúmulo de 7,048 (Figura 2B). Embora tenha ocorrido efeito linear positivo no rendimento de grăos (Figura 2C) esta foi baixa 


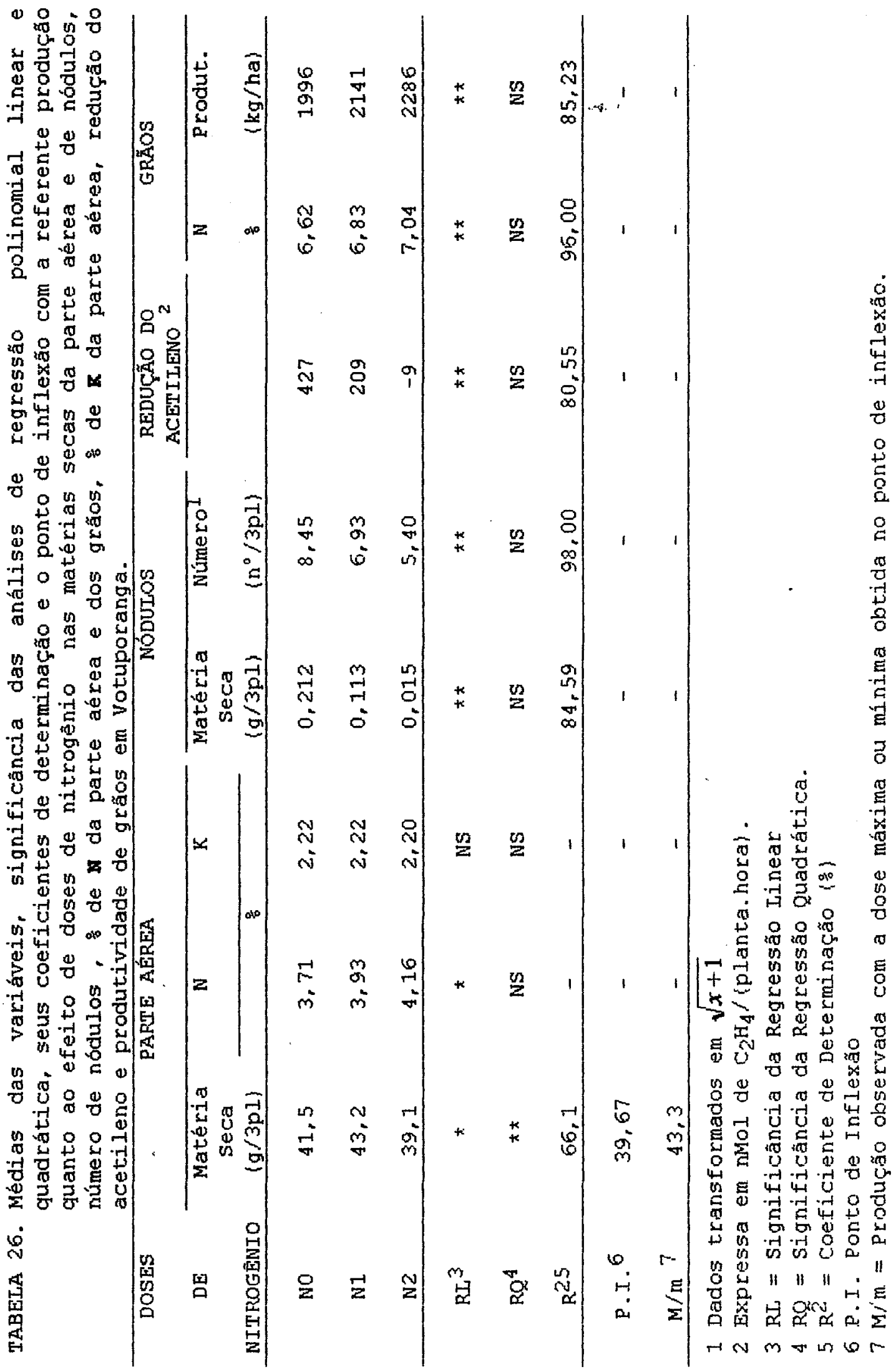


em relação ao potencial dos cultivares. Como o temperatura não foi limitante ao desenvolvimento da planta nessa localidade, suspeita-se que esse efeito seja devido a problemas de manejo do solo e fertilidade.

OHLROGGE (1960) relatou que o rendimento de gråos de soja está intimamente correlacionada com 0 teor de $\mathbf{N}$ da planta. VASILAS \& FUHRMANN (1993) mostraram ainda que essa relação, se for negativa, é um fator limitante à produção.

A matéria seca e o número de nódulos e a atividade total do nódulo foram linearmente reduzidos com o aumento da dose de $\mathbf{N}$ aplicada. Tal comportamento foi verificado anteriormente por WEBER (1966) e EAGLESHAM et al. (1982).

\subsubsection{DOSES DE NITROGÊNIO DENTRO DE CUL- TIVAR}

Houve interaçăo dupla entre doses de $\mathrm{N}$ dentro de cultivares quanto as materias secas da parte aerea e nódulos e número de nódulos (Tabelas 27 e 28 ).

Somente houve resposta para dose de $\mathbf{N}$ na matéria seca da parte aerea no cultivar IAC-8. Houve aumento na materia seca da parte aérea até a dose de $38,42 \mathrm{~kg} / \mathrm{ha}$ de $\mathbf{N}$ (Tabela 27).

Nos dois genótipos de soja estudados, verificouse que houve reduçăo linear na nodulaçăo com o aumento da 


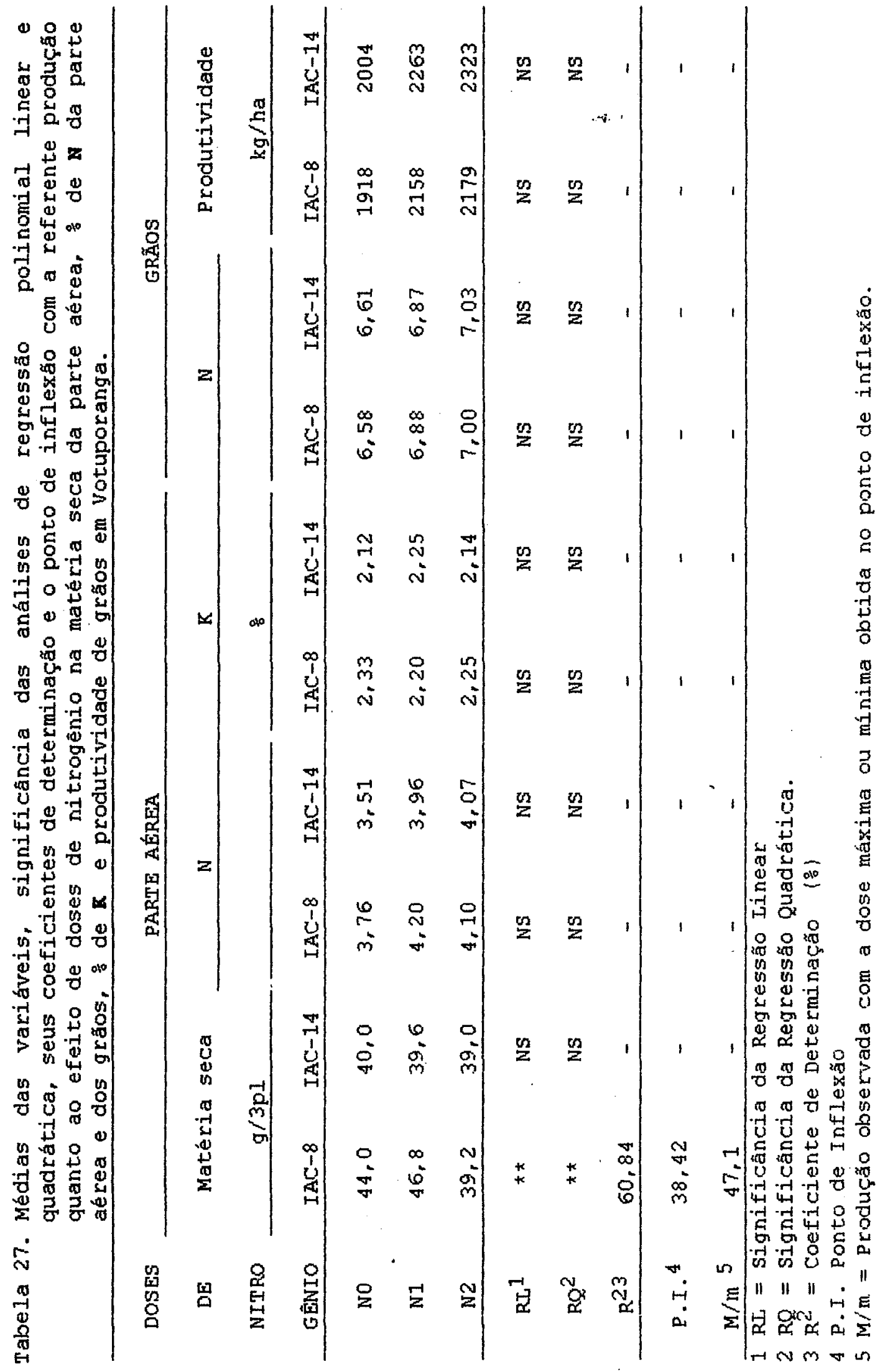




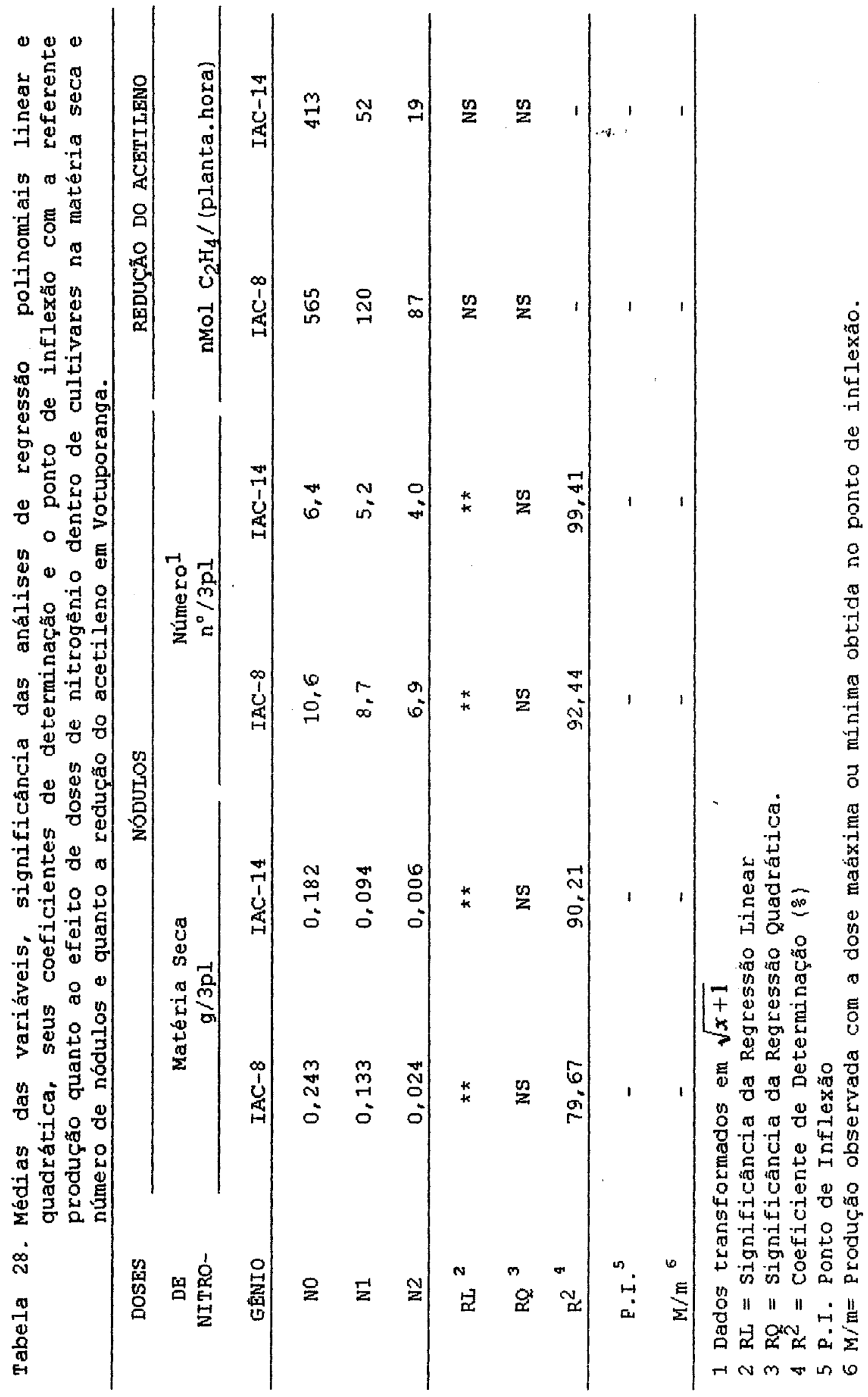


dose de $\mathbf{N}$. A matéria seca dos nódulos de ambos os cultivares foi pequena mesmo sem a adição de $\mathbf{N}$ (Tabela 28 ). TANNER \& ANDERSON (1964)* observaram o mesmo efeito de diminuição na nodulação na presença de $N$ adicional.

\subsubsection{DOSES DE NITROGÊNIO DENTRO DE DOSES DE POTÁSSIO}

Nåo houve resposta a interaçå de doses de $\mathbf{N}$ dentro de doses de potassio em nenhum dos parametros agronomicos estudados (Tabela 29).

somente houve resposta às doses de nitrogenio dentro de doses de potássio na materia seca e no número de nódulos (Tabelas 29 e 30 ).

A materia seca e o número de nodulos em quaisquer dos tratamentos com potássio foram linearmente reduzidos com o aumento da dose de nitrogenio (Tabela 30 ):

\subsection{EFEITO DE DOSES DE POTÁSSIO}

- efeito de doses de potásio nao foi significativo nos tres locais em estudo para os seguintes parametros analisados: 8 de $\mathbf{N}$ da parte aerea, 8 de $\mathbf{K}$ da parte aerea, número de nodulos, : de $\mathbf{N}$ no gráo e rendimento de gráos. Tambem năo houve efeito de doses de potássio em 


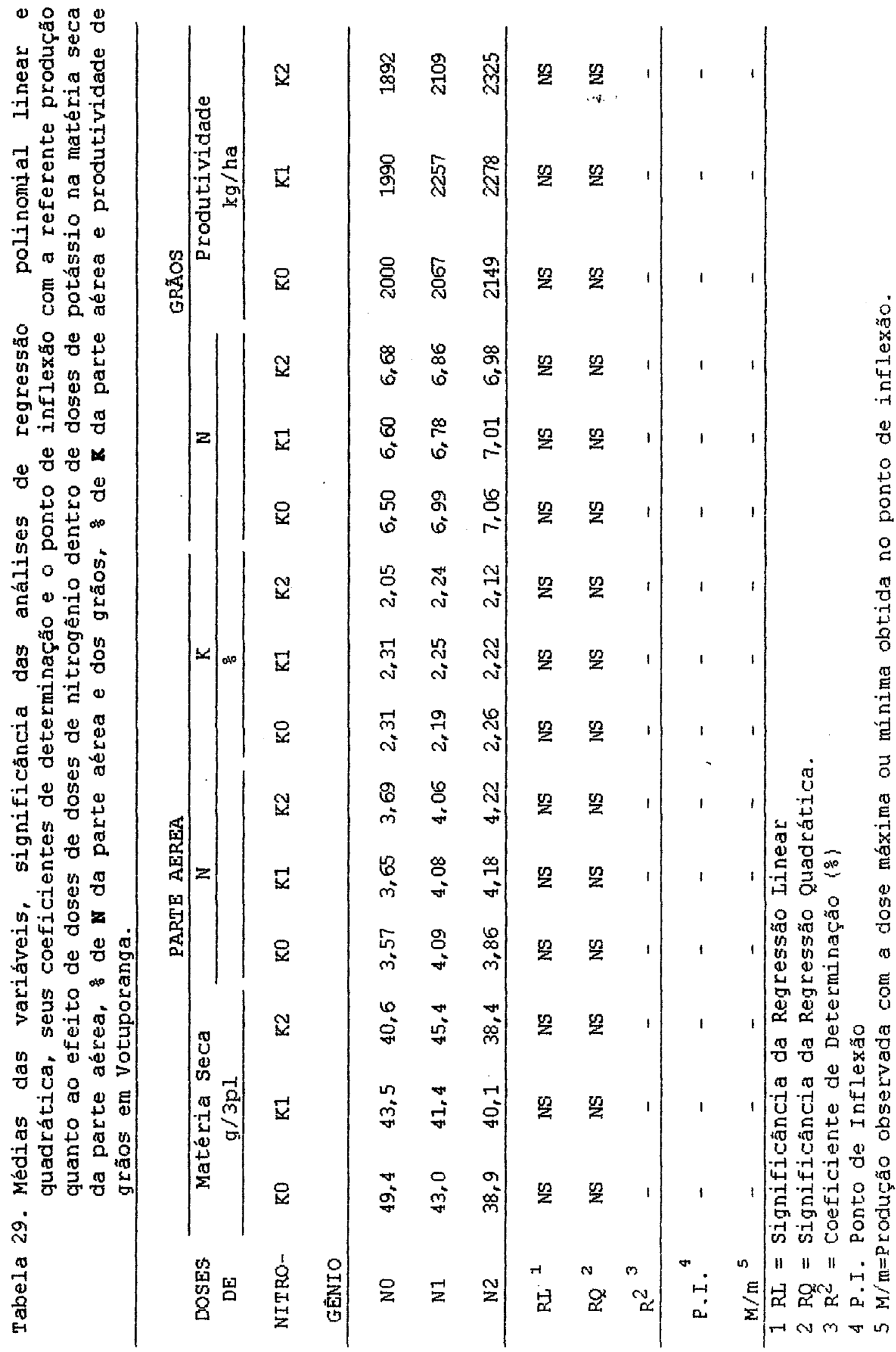




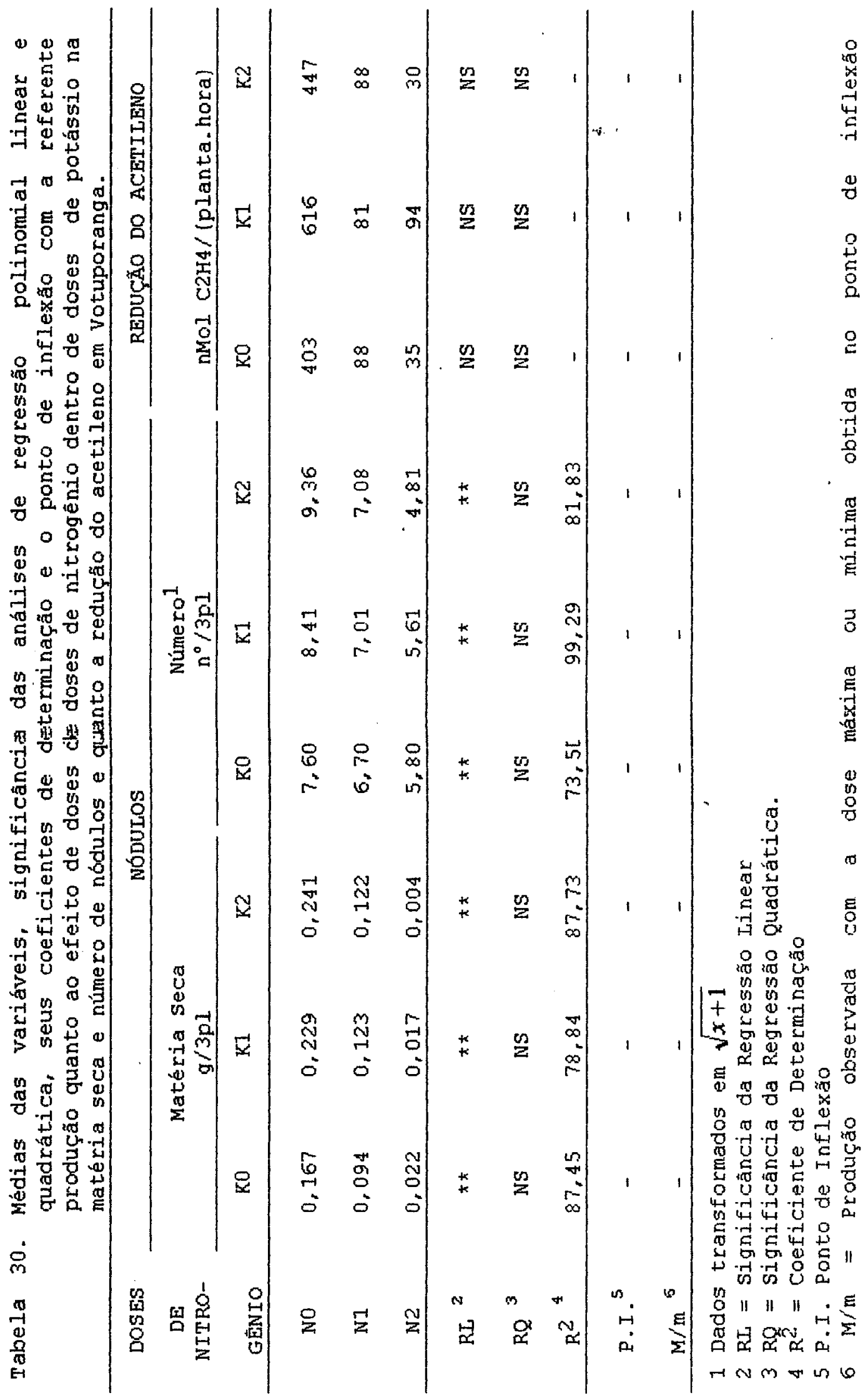


Ribeirão Preto e Votuporanga para massa seca da parte aerea (Tabelas 31,36 e 41).

Os teores de potássio do solo das três áreas experimentais estavam elevados. DUKE \& COLLINS (1985) relataram que quando o teor de potássio do solo é adequado, se o mesmo for adicionado, sua concentraçăo nos tecidos aumenta muito pouco. Nessa mesma condição, observaram ainda que a concentração de $\mathbf{N}$ no tecido permanecia a mesma podendo inclusive diminuir. A ausência de resposta da produtividade de grãos a potássio é explicada por LATHWELL \& EVANS (1951) que observaram que esse parametro está intimamente associado com a quantidade de $\mathbf{N}$ acumulado dentro da planta. MUZILLI (1982) constatou que a maior disponibilidade de potássio no solo não correspondeu a maior rendimento de grãos.

\subsubsection{MOCOCA}

Pode-se observar que a materia seca da parte aerea foi linearmente reduzida com o aumento da dose de potássio ocorrendo o inverso para a atividade total do nódulo (Tabela 31). BARTA (1982) observou que ao contrário do que ocorreu nesse experimento, $\theta$ peso seco da parte aérea era significativamente aumentado com a adiça de potássio.

A matéria seca de nódulo foi reduzida com o 


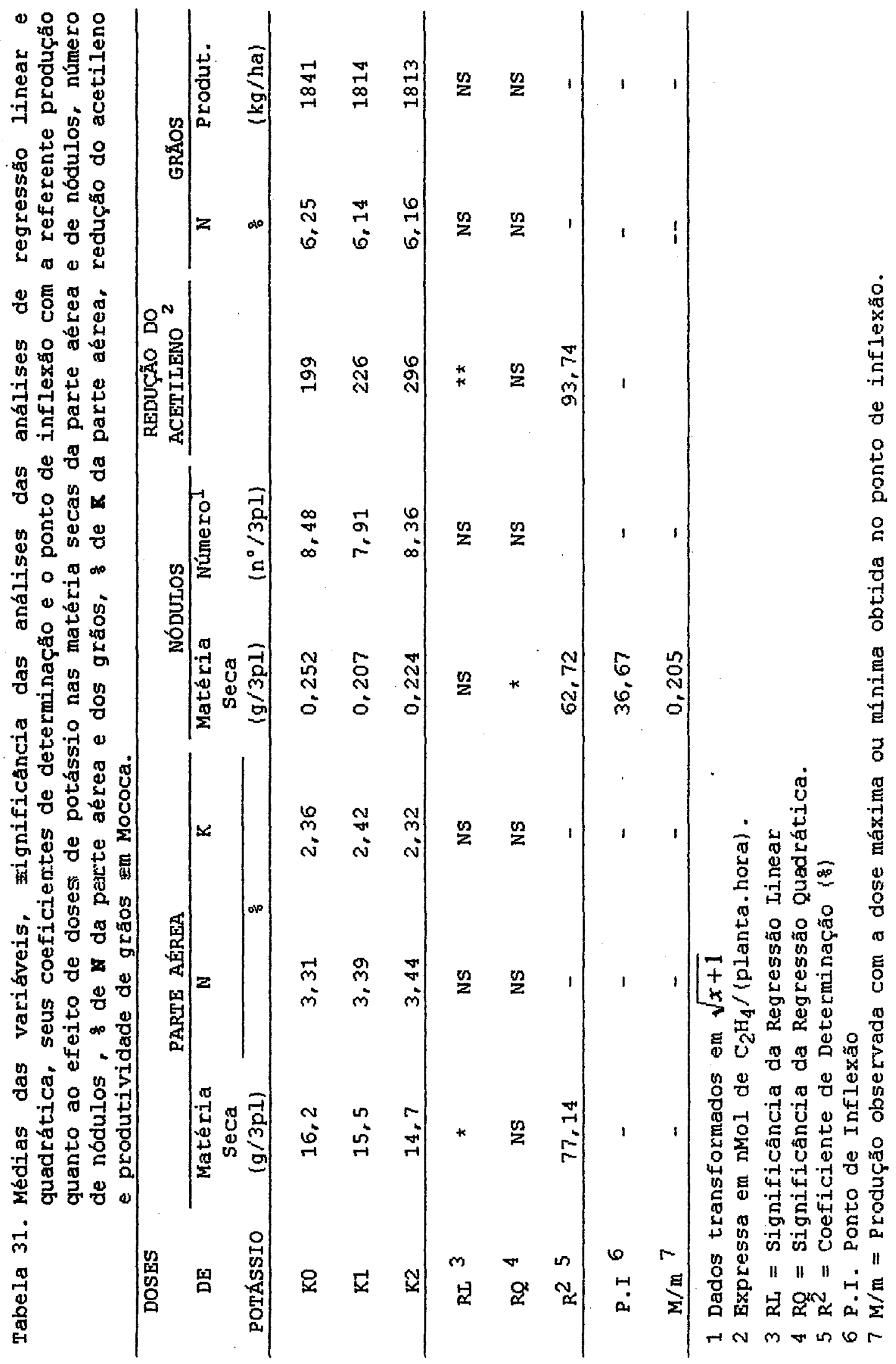


aumento da dose de potássio até a adição de $36,67 \mathrm{~kg} / \mathrm{ha}$ de $\mathrm{K}_{2} \mathrm{O}$ (Tabela 31). ERANCO \& DOBEREINER (1967) também observaram maiores valores de massa e maiores quantidade de nódulos onde nå havia sido aplicado potássio.

\subsubsection{DOSES DE POTÁSSIO DENTRO DE CULTI- VAR}

Houve interação de doses de potássio dentro dos dois cultivares em estudo para os seguintes parametros analisados: matéria seca da parte aérea, matéria seca de nódulos, número de nódulos e atividade total do nódulo. (Tabelas 32 e 33). A nåo diferença entre variedades quanto à produtividade em relaçåo a potássio já havia sido relatada por FRANCO \& DOBEREINER (1967) em feijoeiro.

A materia seca da parte aérea do cultivar IAC-8 foi linearmente reduzida com o aumento da dose de potássio e, a do IAC-14 aumentou seguindo uma equação do segundo grau até a doses de $30,13 \mathrm{~kg} / \mathrm{ha}$ de $\mathbf{K}_{2} \mathrm{O}$ (Tabela 32). BARTA (1982) observou que em solos com mais de 3o de potássio, 0 crescimento vegetativo era aumentado mas, năo relata ser esse aumento dependente da variedade.

Embora JONES et al. (1977) tenham observado que o efeito de potássio na nodulação são inconsistentes, pode-se observar que tanto a materia como o número de nódulos no IAC-8 foram reduzidos com o aumento do potássio aplicado 


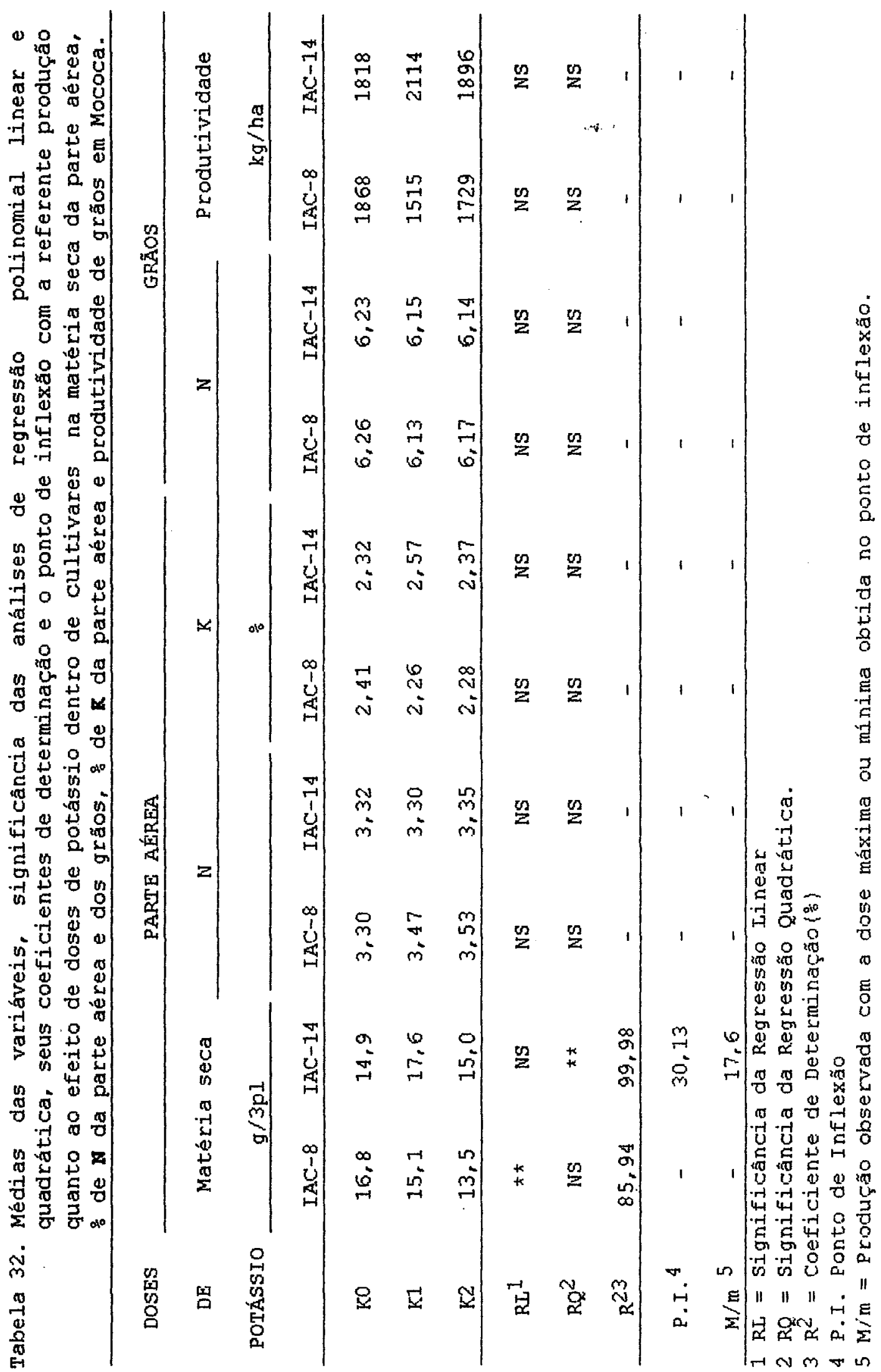




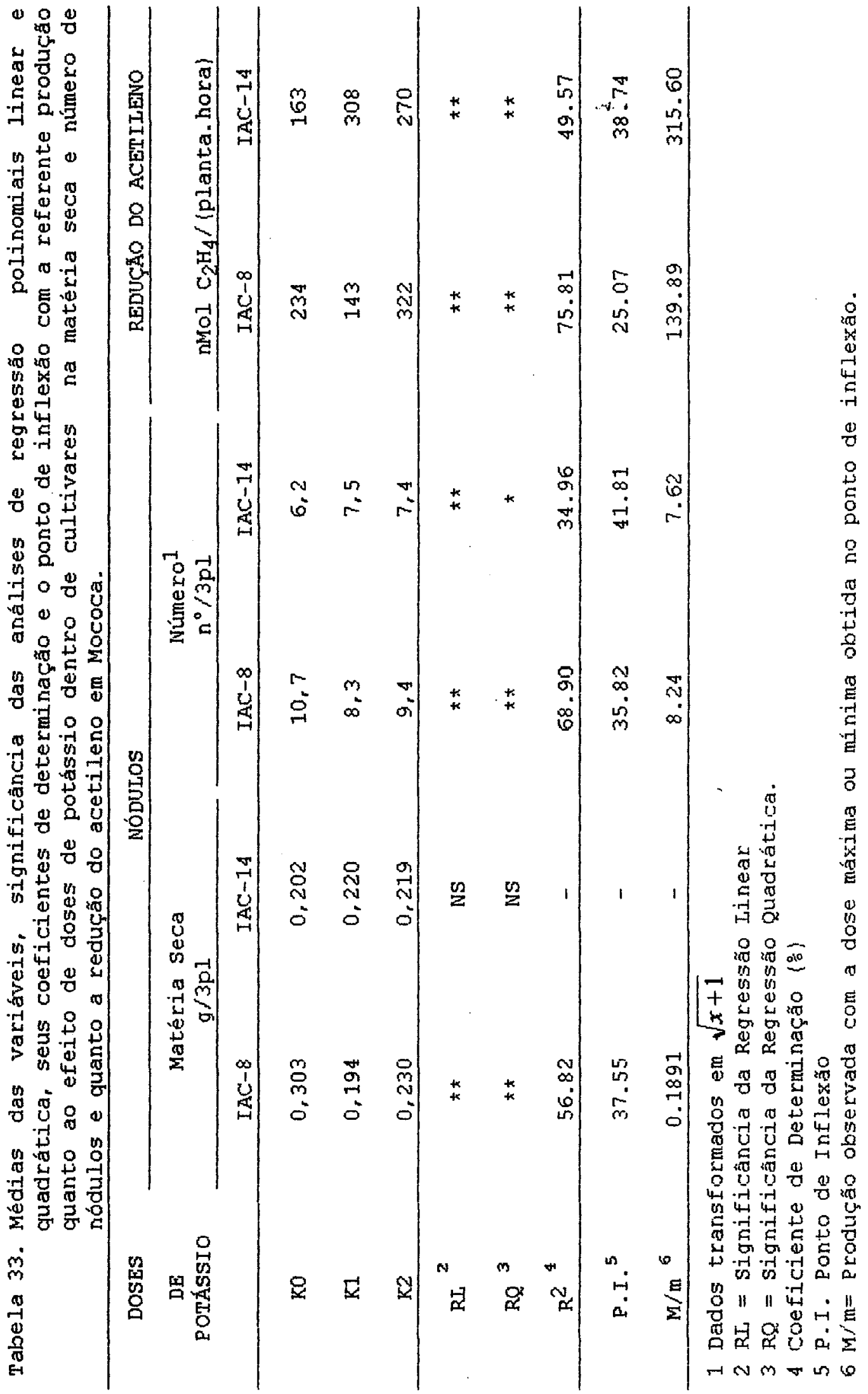


segundo uma equação quadrática. Entretanto, o número de nódulos do cultivar IAC-14 foi aumentado até a adição de 40 $\mathrm{kg} / \mathrm{ha}$ de $\mathbf{K}_{2} \mathrm{O}$ (Tabela 33). STAMFORD et al. (1980) observaram que há efeito depressivo do potássio no número de nódulos relatando que o nível desse elemento para que haja formação de nódulos deve ser baixo.

A atividade total do nódulo do cultivar IAC-8 foi reduzida pelo aumento da dose de potássio segundo uma equação do segundo grau. No cultivar IAC-14 verificou-se que a atividade total do nódulo mostrou um comportamento quadrático positivo (Tabela 33). Por esses dados verificouse uma maior resposta do cultivar IAC-14 à adiçao de potássio.

DUKE \& COLLINS (1985) observaram que quando o potássio afetava a produtividade do nódulo, ocorria uma correlação baixa entre massa nodular e fixaçåo de nitrogênio. Isso ocorria porque nódulos com a mesma massa tem taxas muito diferentes de fixação de nitrogênio.

\subsubsection{DOSES DE POTÁSSIO DENTRO DE DOSES DE NITROGÊNIO}

Nå houve interaçăo entre doses de potássio e de de nitrogenio em nenhum dos parametros agronómicos estudados (Tabela 34 ).

Houve interação somente para matéria seca e 


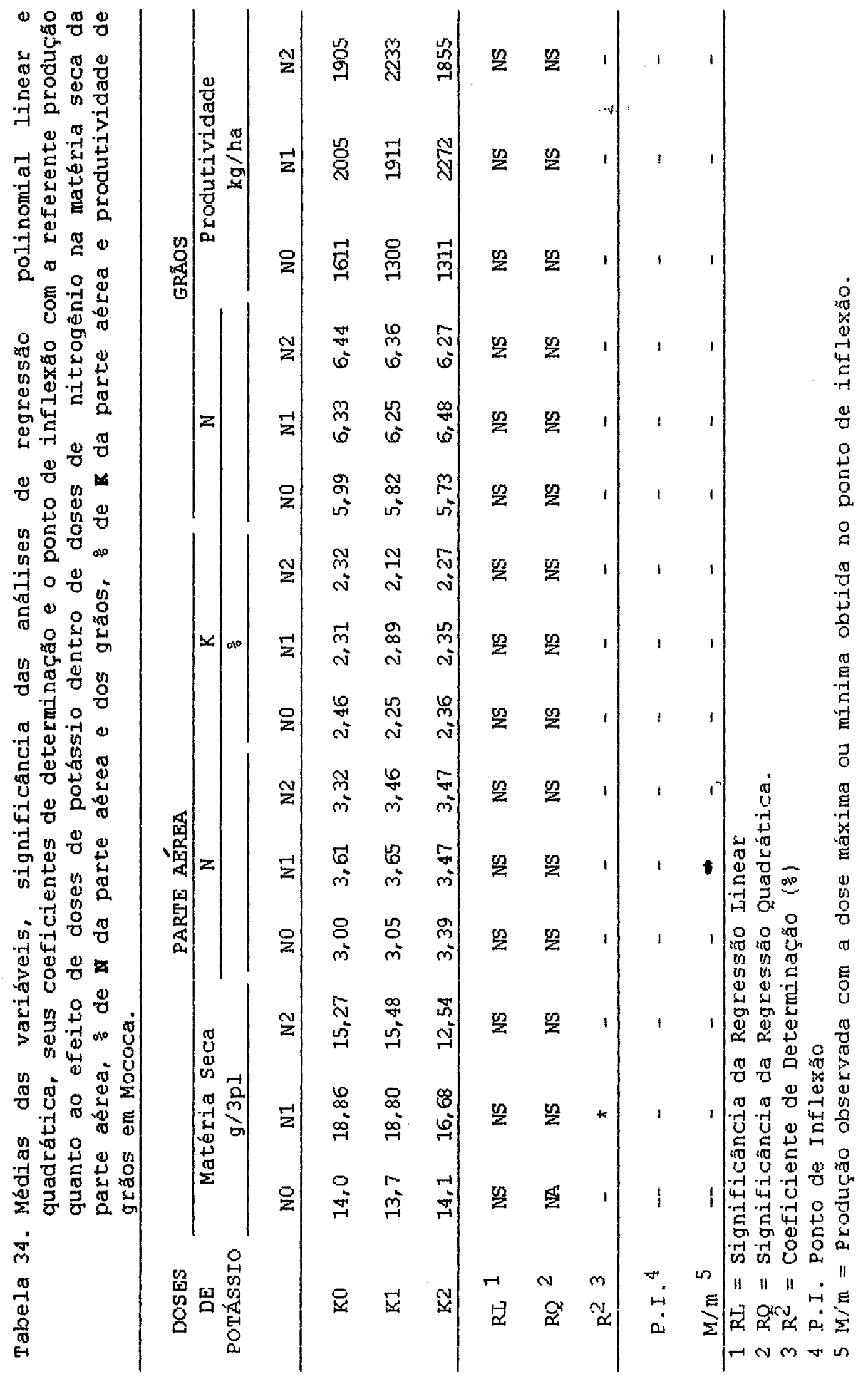


número de nódulos e atividade total (Tabela 35). A matéria seca e o número de nódulos nos tratamentos sem nitrogênio foram reduzidos até a adição de $20,85^{4.4}$ e $17,35 \mathrm{~kg} / \mathrm{ha}$ de $\mathbf{K}_{2} \mathrm{O}$, respectivamente. Com a adição de nitrogênio $\left(\mathbf{N}_{1}\right.$ e $\left.\mathbf{N}_{2}\right)$, ambos os parâmetros foram linearmente reduzidos com $\circ$ aumento da dose de potássio nao sendo, entretanto, significativo para número de nódulos a dose $\mathbf{N}_{2}$ (Tabela 35 ) .

A atividade total do nódulo cresceu linearmente com o aumento da dose de potássio em tratamentos onde não foi aplicado nitrogênio (Tabela 35). Com a adição de $\mathbf{N}_{1}$, a atividade aumentou com a dose de potássio seguindo uma equação quadrática positiva. A adição de $\mathbf{N}_{2}$ reduziu a atividade total do nódulo até a adição de $39,34 \mathrm{~kg} / \mathrm{ha}$ de $K_{2}$ o. TSAI et al. (1993) verificaram que quando quantidades baixas de uréia são adicionados ao feijoeiro, há um aumento substancial da nodulação e, conseqüentemente, altas quantidades de nitrogênio fixado são obtidos, com aumentos correspondentes na biomassa da planta.

FRANCO \& DOBEREINER (1967) verificaram, como nesse experimento, que o potássio foi prejudicial para a simbiose e a fixação do nitrogenio. DUKE et al. (1980) explicaram que $\bigcirc$ potássio favorecia $\circ$ aumento da disponibilidade de fotossintetizado mas, não aumentava necessariamente a nodulação ou a ação da nitrogenase. 


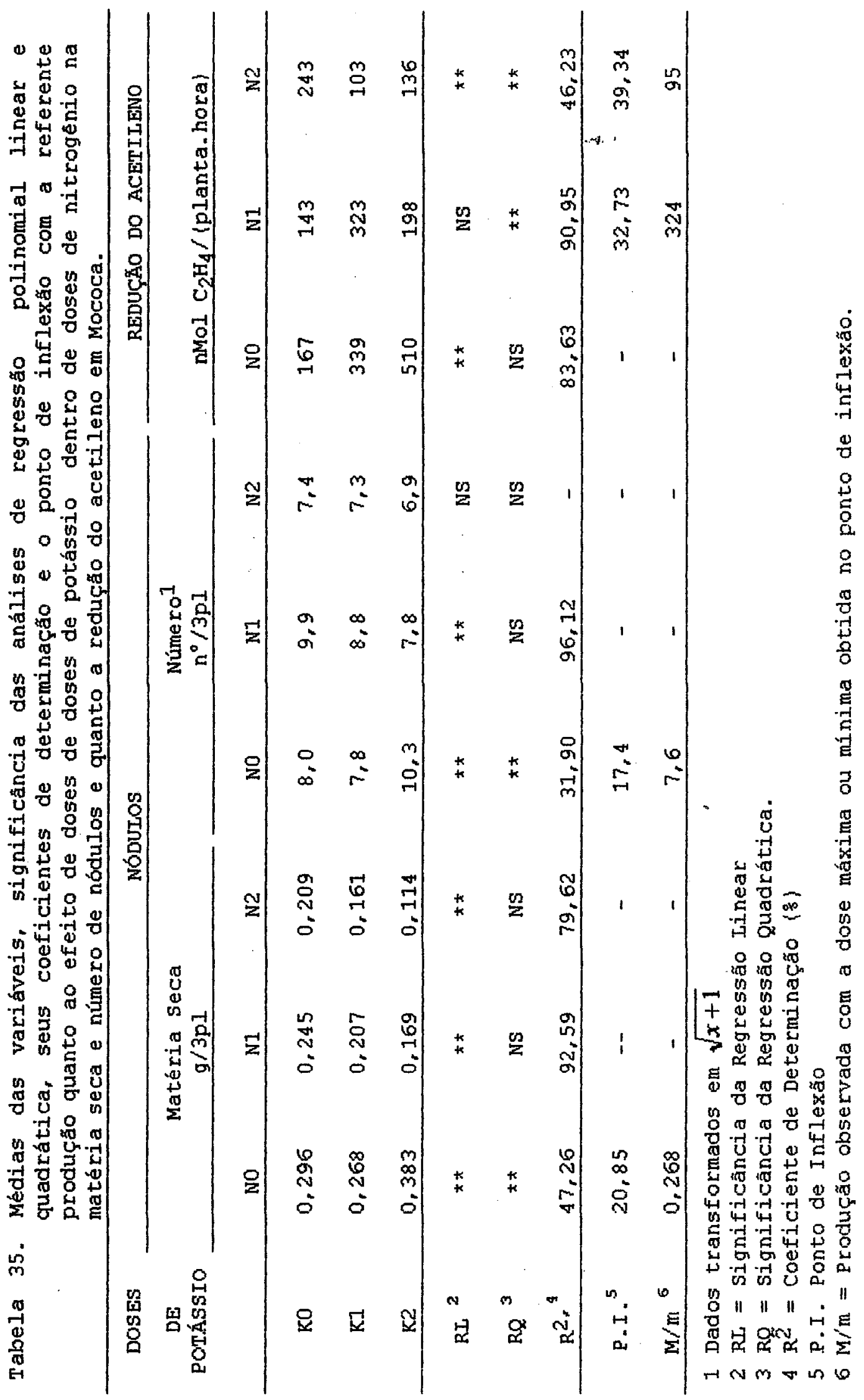




\subsubsection{RIBEIRÃO PRETO}

Analisando-se o efeito de doses de potássio nos diferentes parâmetros pode-se observar que houve significancia apenas para a matéria seca de nódulos com o aumento da dose de potássio ( $\mathrm{T} a b e l a$ 36). A matéria seca de nódulo foi reduzida com o aumento da dose de potássio, estimando-se que atingirla um produçäo minima com a adiçäo de $25,10 \mathrm{~kg} / \mathrm{ha}$ de $\mathrm{k}_{2} \mathrm{O}$.

A atividade total do nódulo foi linear e positivamente aumentada com o aumento da dose de potássio.

DUKE \& COLLINS (1985) verificaram que a fixação do nitrogênio aumentava com a adição de potássio. Esse aumento na fixação devido a esse elemento pode ser atribuído ao aumento da nodulação, da produtividade dos nódulos ou, de ambos.

\subsubsection{DOSES DE POTÁSSIO DENTRO DE CULTI- VAR}

Nas condiçöes de Ribeiráo preto, o efeito de doses de potássio dentro de cultivares, nao foi significativo para nenhum dos parametros agronòmicos (Tabela 37). Foi significativo no cultivar IAC-14 para a massa seca de nódulos (Tabela 38). O efeito foi do tipo quadrático correspondendo a um ponto de minimo ao 


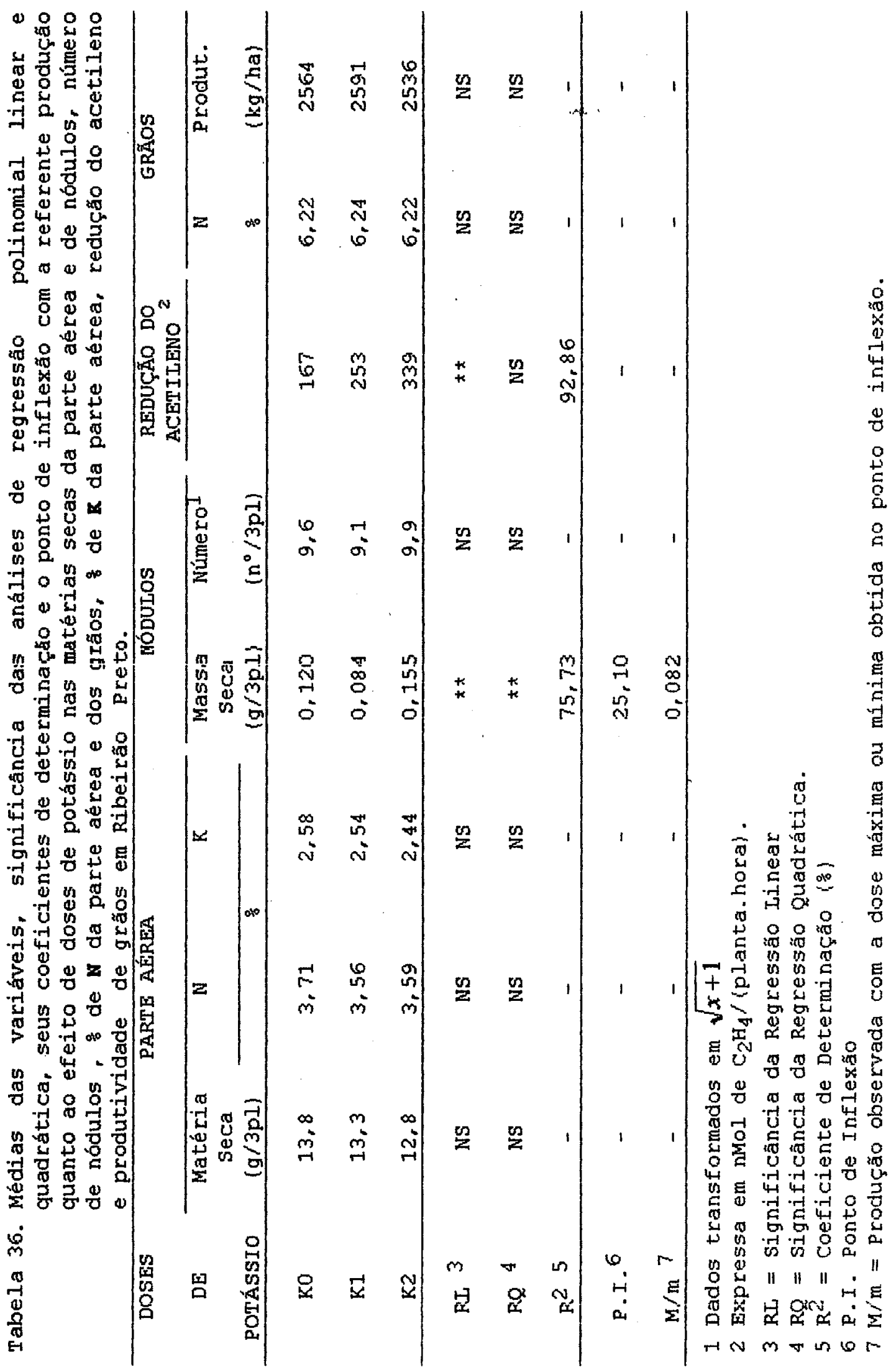




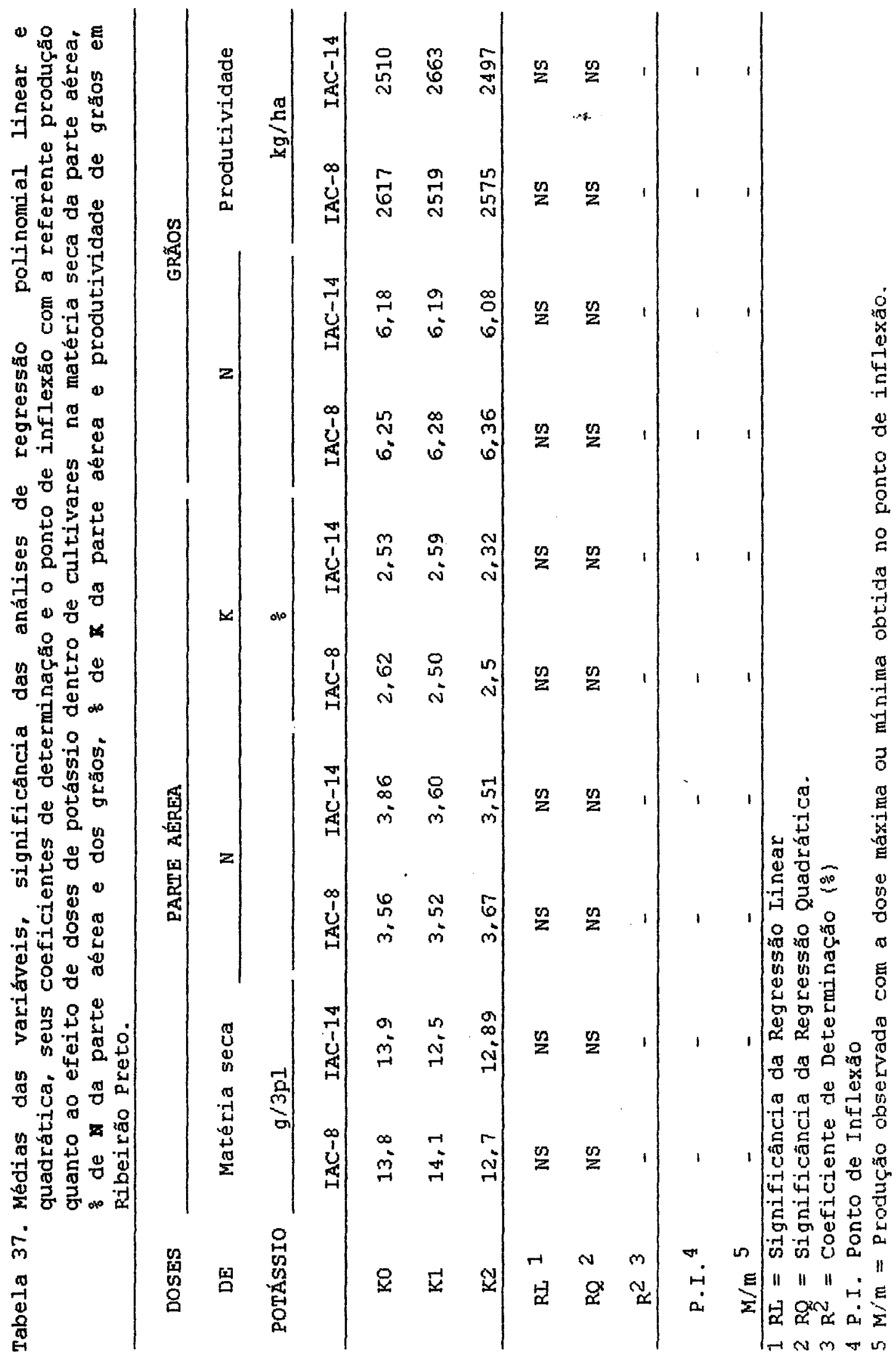




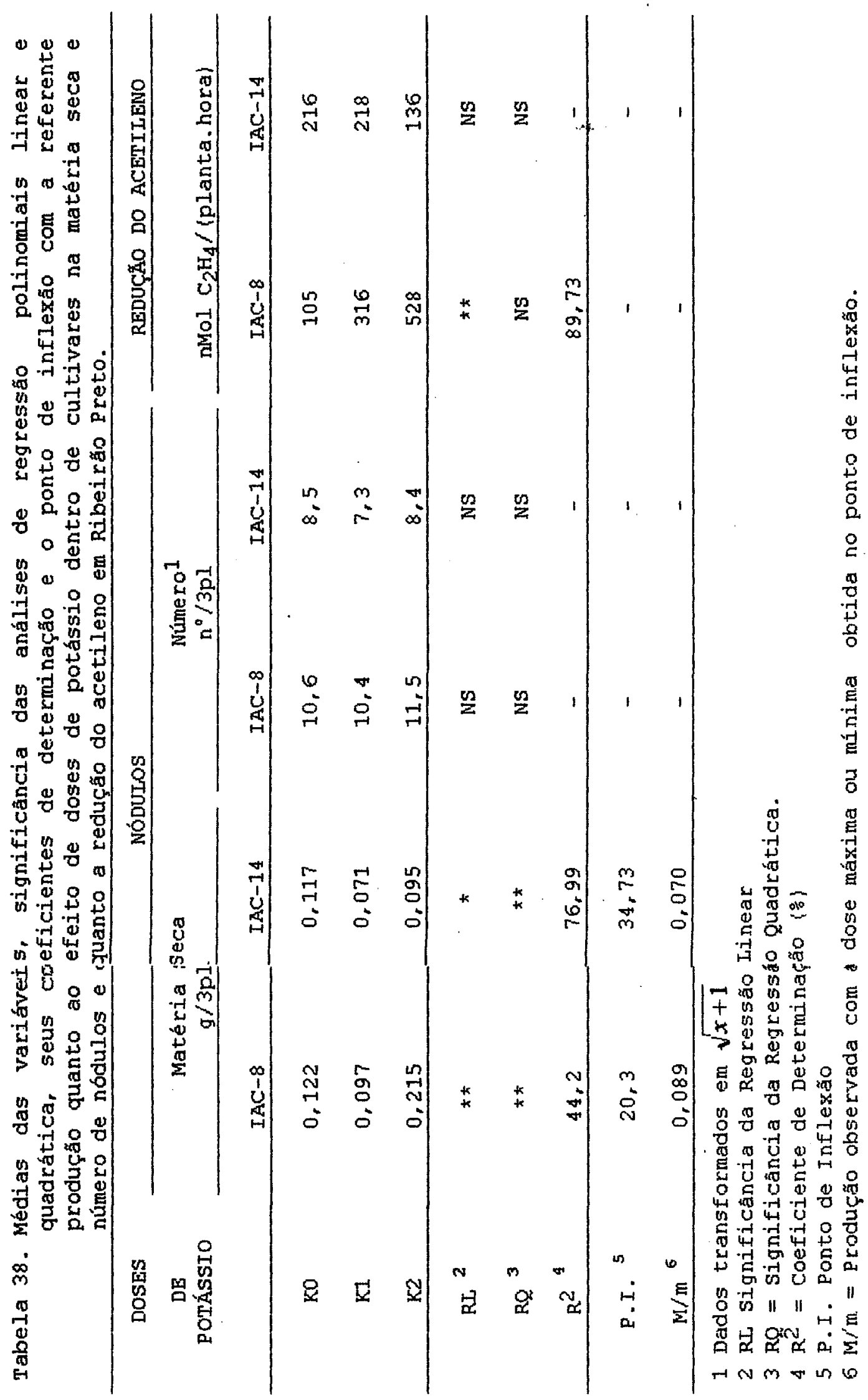


fornecimento de $35 \mathrm{~kg} / \mathrm{ha}$ de $\boldsymbol{K}_{2} \mathrm{O}$.

No cultivar IAC-8, houve significancia para matéria seca de nódulos e atividade total do nódulo. A regressão significâtiva foi quadrática negativa para matéria seca'de nódulos, sendo o ponto mínimo atingido pelo fornecimento de $20 \mathrm{~kg} / \mathrm{ha}$ de $\mathbf{K}_{\mathbf{2}} \mathrm{O}$.

A atividade total do nódulo se ajustou a uma função linear crescente com o aumento da dose de potássio somente no cultivar IAC-8 (Tabela 38 ).

O efeito diferencial do potássio para variedades ou linhagens já havia sido observado por ERANCO \& DOBEREINER (1967). A exigência de potássio também varia com - genótipo e o estágio de desenvolvimento, como observaram DUKE \& COLLINS (1985) .

\subsubsection{DOSES DE POTÁSSIO DENTRO DE DOSES DE NITROGÊNIO}

As médias da interação de doses de potássio dentro de doses de nitrogenio nos diferentes parametros sao apresentados nas Tabelas 39 e 40 .

A associação entre No e doses de potássio aumentou a materia seca da parte aerea, estimando-se que com a adição de $28,56 \mathrm{~kg} / \mathrm{ha}$ de $\mathbf{k}_{2} \mathrm{O}$ atingiria a produçăo máxima da parte aérea. Entretanto, com a adiçăo de $\mathbf{N}_{2}$, ocorreu reduça linear na materia seca da parte aerea com o 


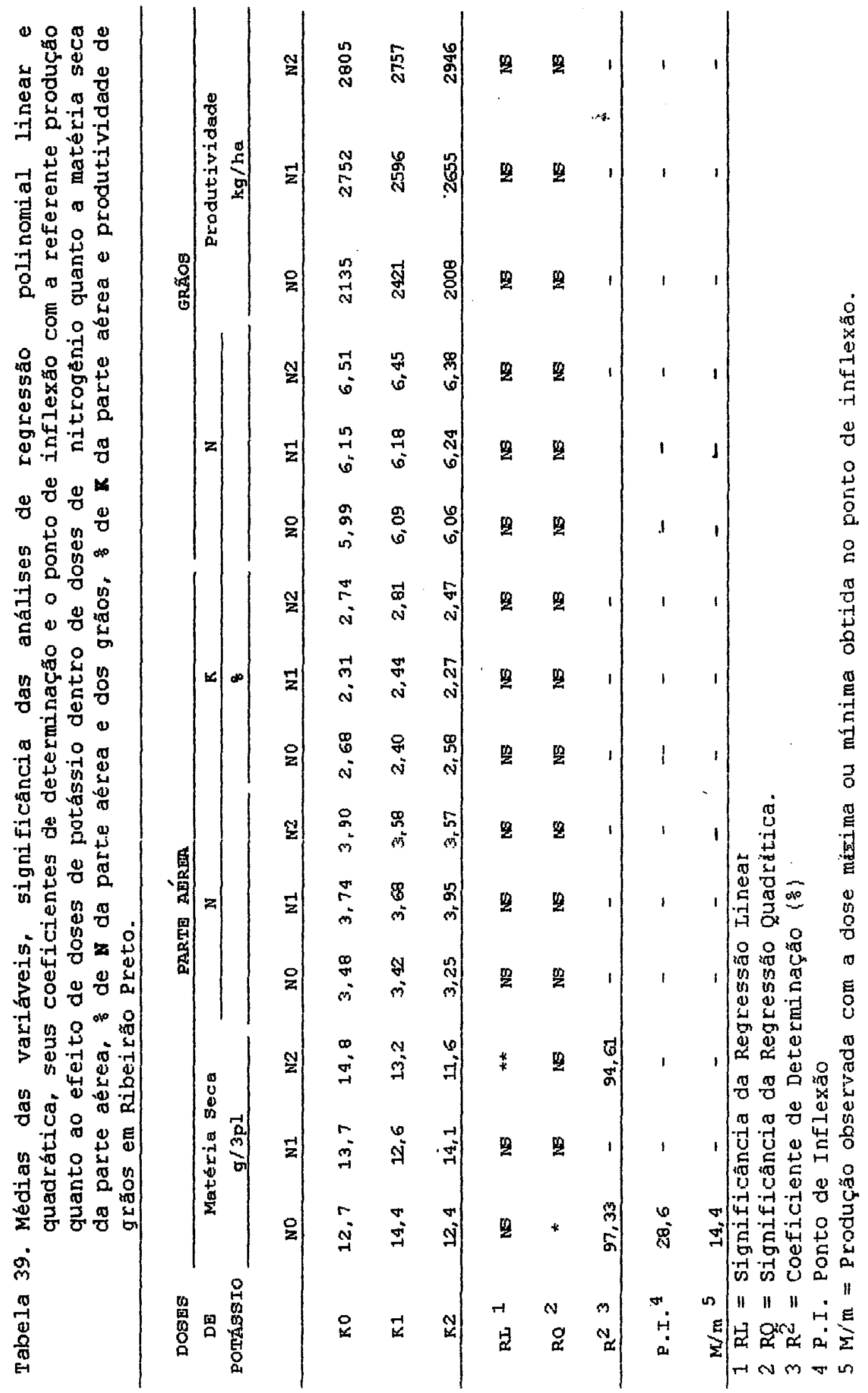




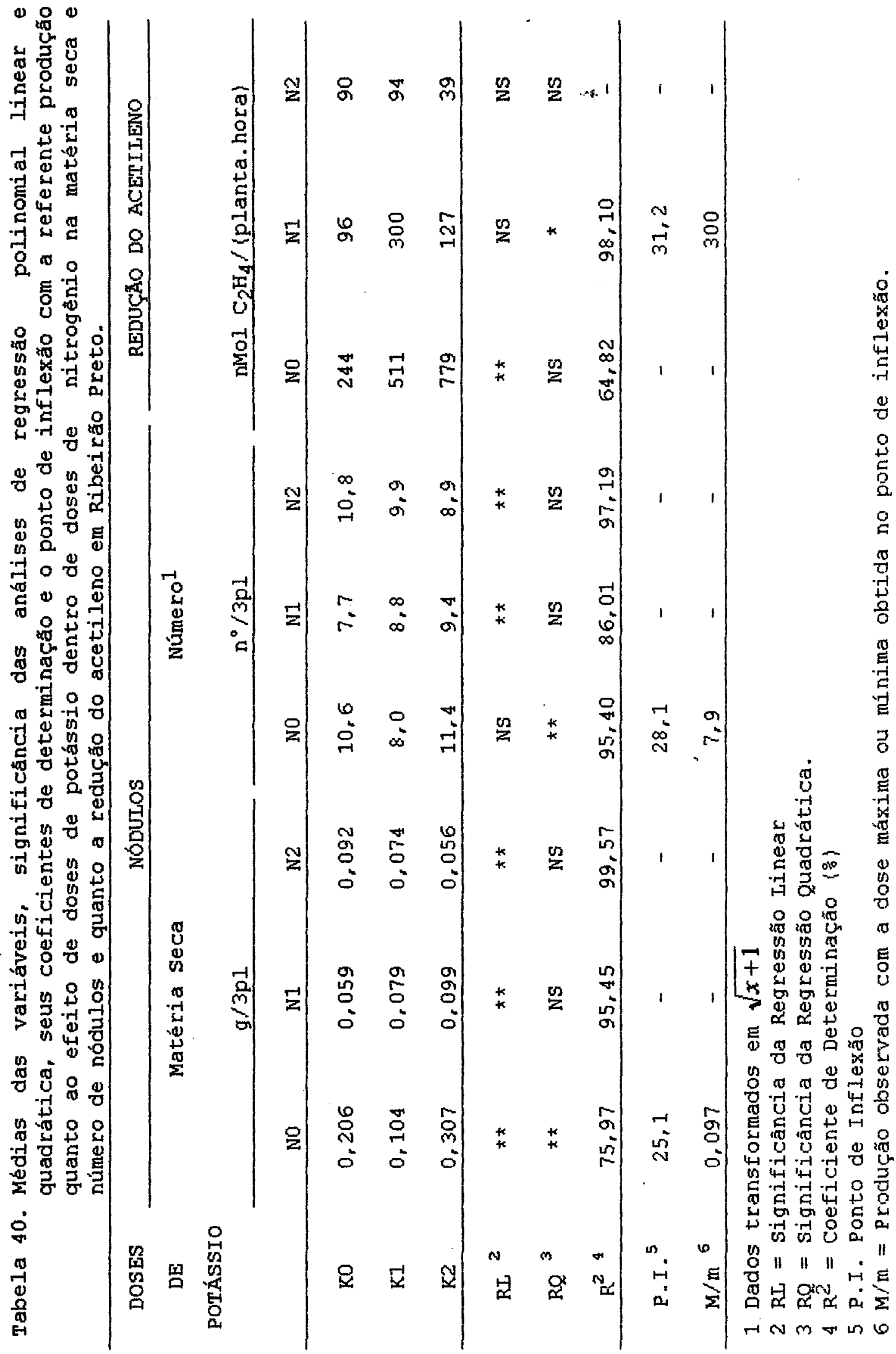


aumento da dose de potássio (Tabela 39).

Tanto a massa nodular como o número de nódulos apresentaram o mesmo comportamento em relação a interação de doses de potássio dentro de doses de nitrogenio. Ambos os parametros, no tratamento sem $\mathbf{N}$, foram reduzidos com 0 aumento da dose de potássio atingindo um ponto mínimo com a dose estimada de 25,1 e $28,1 \mathrm{~kg} / \mathrm{ha}$ de $\mathbf{K}_{2} \mathrm{O}$, respectivamente (Tabela 40). Com a adiçăo de $\mathbf{N}_{1}$, tanto a matéria seca como - número de nódulos foram iinearmente aumentados com o aumento da dose de potássio; ocorreu o oposto no tratamento $\operatorname{com} \mathbf{N}_{2}$.

Houve aumento linear na atividade total dos nódulos com o aumento da dose de potássio no tratamento sem $\mathbf{N}$. No tratamento $\operatorname{com} \mathbf{N}_{\mathbf{1}}$, houve aumento na atividade total do nódulo, estimando-se uma fixação máxima com a adição de $31,20 \mathrm{~kg} / \mathrm{ha}$ de $\mathrm{K}_{2} \mathrm{O}$ (Tabela 40 ).

THOMAS \& HUNGRIA (1988) observaram que o potássio pode contribuir para o transporte do $\mathbf{N}$ fixado dos nódulos para os orgãos reprodutivos. Verificaram também que quando se adicionava doses acima de $40 \mathrm{mg} / \mathrm{kg}$ de solo havia efeito sinergístico do N mineral sobre a nodulação.

Em relação a atividade específica do nódulo, verificou-se que no tratamento sem nitrogenio, com o aumento da dose havia aumento linear na fixação (Tabela 40). Já com a aplicação de $\mathbf{N}_{1}$, ocorria um aumento na atividade total do nódulo até a dose de $31,2 \mathrm{~kg} / \mathrm{ha}$ de $\mathbf{k}_{2} \mathrm{O}$. 
Não houve resposta à doses de potássio quando se aplicou $\mathbf{K}_{2}$.

\subsubsection{YOTUPORANGA}

Somente houve efeito de doses de potássio em Votuporanga na matéria seca dos nódulos e na atividade total dos nódulos (Tabela 41). Houve aumento linear positivo na na matéria seca de nódulos com o aumento da dose de potássio aplicada. O mesmo comportamento foi tambem verificado por JONES et al. (1977). O efeito na atividade total do nodulo foi positivo e quadrático. Verificou-se que ocorreria ponto de máxima fixação na dose de $31,21 \mathrm{~kg} / \mathrm{ha}$ de $\mathrm{K}_{2} \mathrm{O}$.

4.3.3.1. DOSES DE POTÁSSIO DĖNTRO DE CULTIVAR

Houve interação significativa entre doses de potássio e cultivares somente quanto ao teor de $\mathbf{N}$ da parte aérea e matéria seca e número de nódulos (Figura 3 ).

Em relação ao teor de $\mathbf{N}$ da parte aérea (Figura 3A) O efeito de doses de potássio no cultivar IAC-14 foi do tipo quadrático estimando-se que ocorreria um acúmulo máximo com a adição de $39,06 \mathrm{~kg} / \mathrm{ha}$ de $\mathrm{K}_{2} \mathrm{O}$.

A nodulaçăo foi positivamente afetada pelo aumento das doses de potássio (Figuras 3B e 3C). A materia 


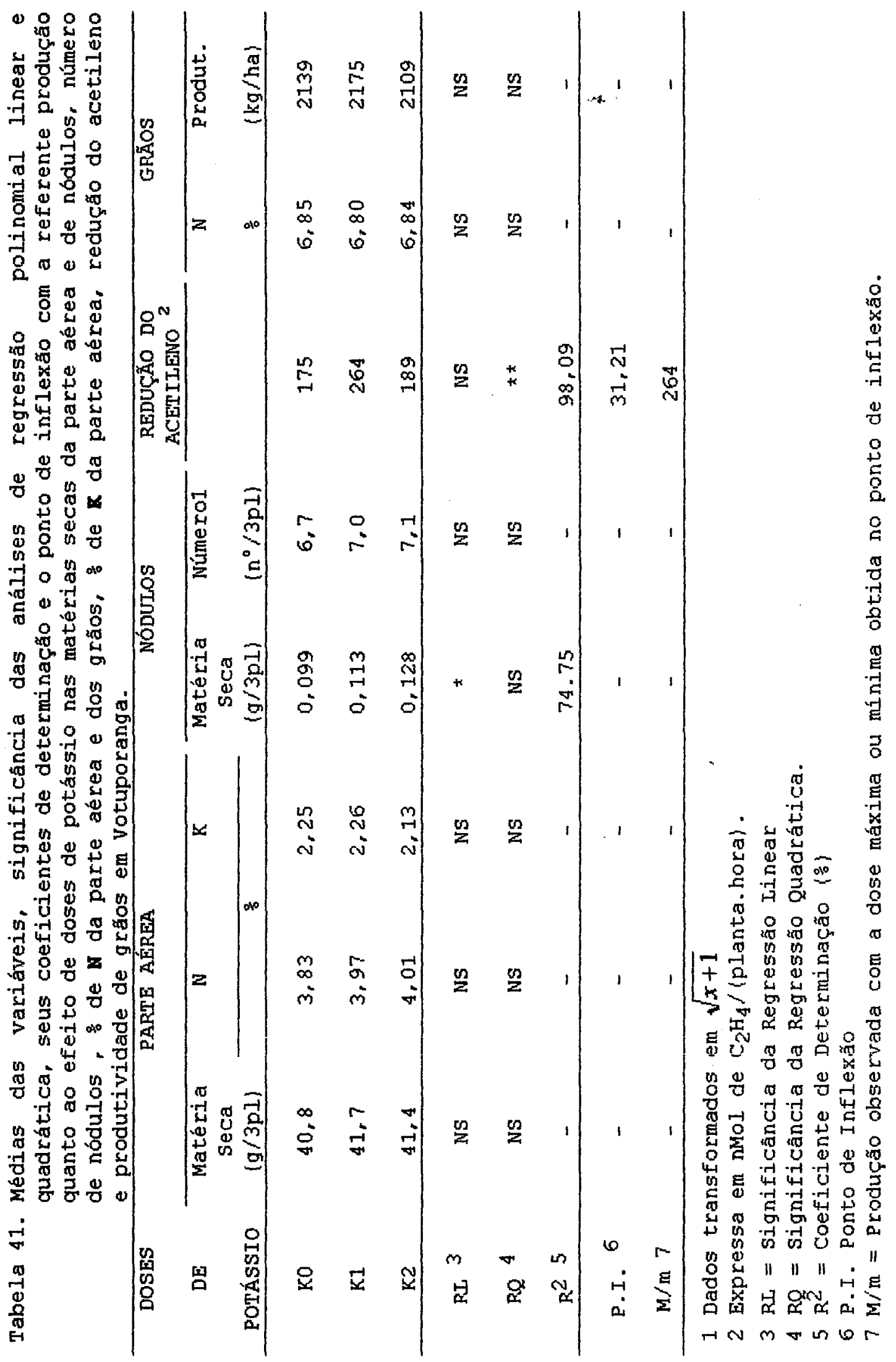




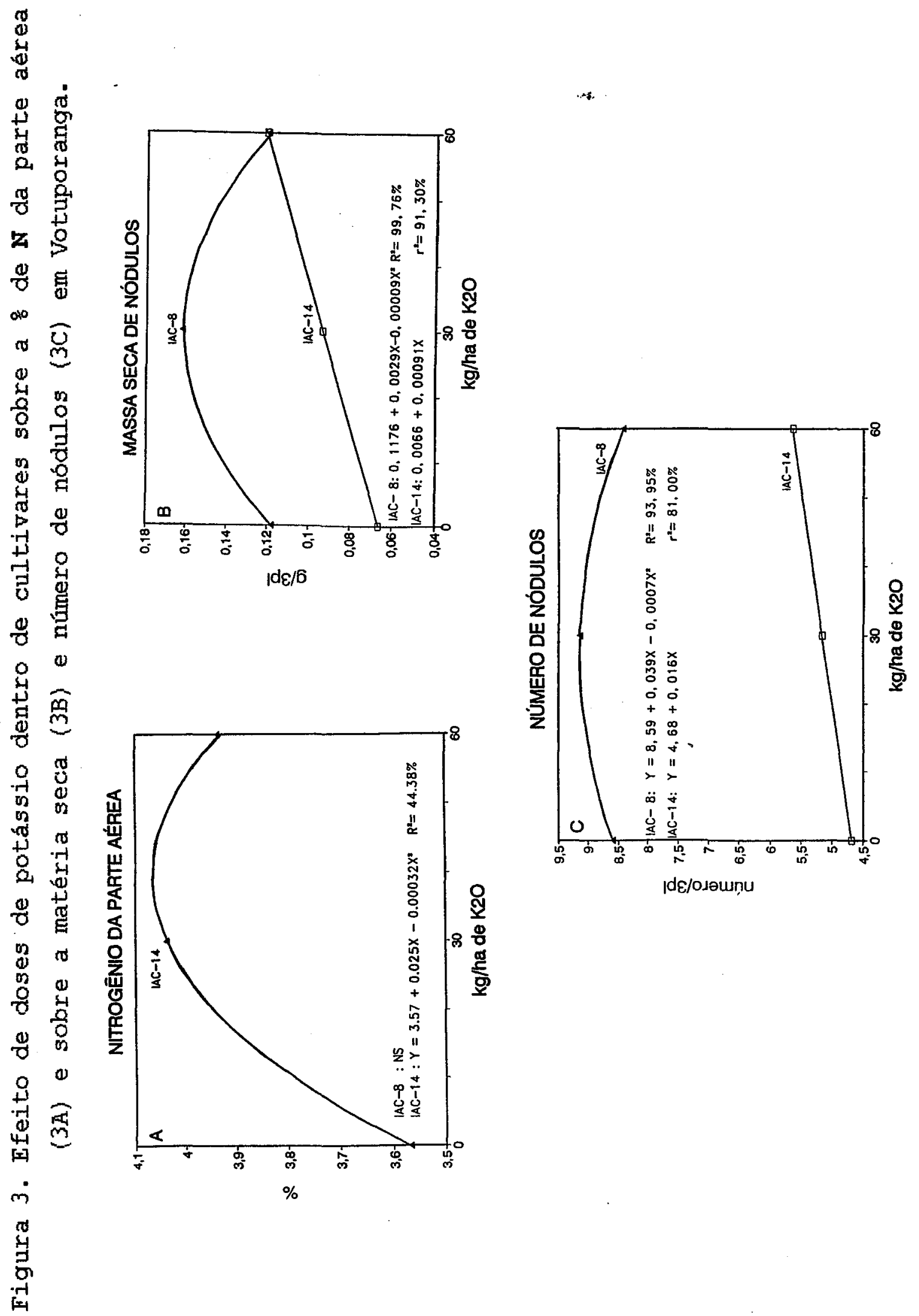


seca e o número de nódulos no cultivar IAC-8 seguiram uma equação do segundo grau com coeficientes de determinaçăo elevados. Estimou-se que ocorreria aumento na materia e no número de nódulos até a adição de 30,42 e $27,86 \mathrm{~kg} / \mathrm{ha}$ de $\mathbf{K}_{2} \mathrm{O}$, respectivamente. Com a aplicação de $60 \mathrm{~kg} / \mathrm{ha}$ de $\mathbf{K}_{2} \mathrm{O}$ tanto a matéria seca como o número de nódulos praticamente se igualavam com o tratamento sem potássio.

No cultivar IAC-14, verificou-se que a nodulação foi linear e positivamente aumentada com o aumento da dose de potássio (Eiguras $3 B$ e $3 C$ ).

\subsubsection{DOSES DE POTÁSSIO DENTRO DE DOSES DE NITROGÊNIO}

Em relação ao efeito de doses de potássio dentro de doses de nitrogénio verificou-se que somente houve resposta para a nodulação (Figuras $4 \mathrm{~A}$ e 4B). Para os dados de matéria seca de nodulos observou-se que somente onde nao foi aplicado $\mathbf{N}$ houve resposta a potássio. Nos tratamentos sem $\mathbf{N}$, observou-se que houve aumento linear na massa nodular com 0 aumento da close de $\mathbf{k}_{2} \mathrm{O}$ (figura $4 \mathrm{~A}$ ). A aplicação de $\mathbf{N}_{1}$ e $\mathbf{N}_{2}$ nåo se ajustou a nenhuma funçăo matemática. Já para número de nódulos (Figura 4B) verificou-se que ocorreria aumento linear com o aumento das doses de potássio quando tratados com $\mathbf{N}_{0}$ e $\mathbf{N}_{1}$. Quando da 


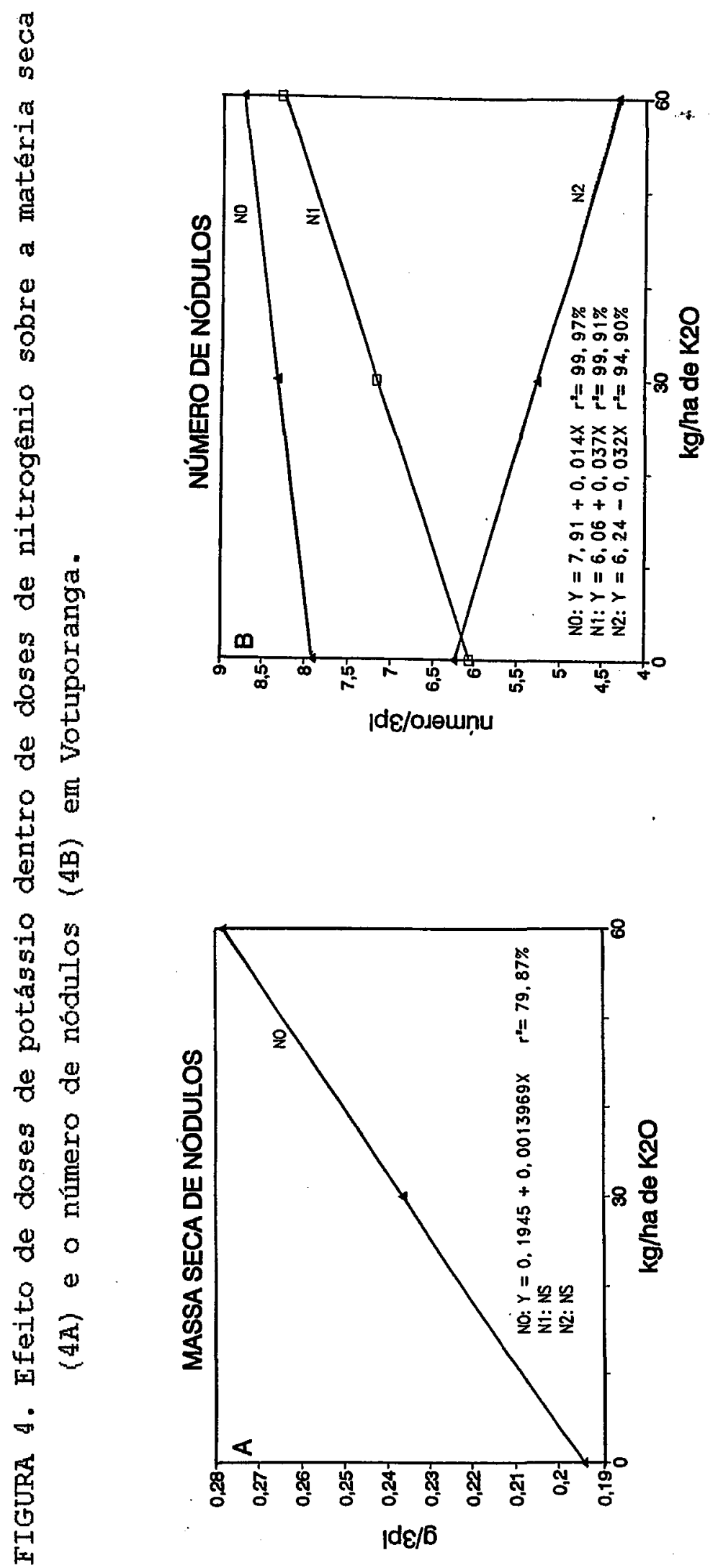


adiçăo de $\mathbf{N}_{2}$ oconreria diminuiça do número de nodulos com - aumento da dose de potássio adicionada. 


\section{CONCLUSÕES}

Com os resultados obtidos nesse experimento podese concluir que:

1) Apenas a inoculação da sementes com as estirpes recomendadas não forneceu nitrogênio em quantidades exigidas para a máxima produtividade, em condições de inverno, nos três locais estudados.

2) A adição de nitrogênio afetou negativamente o processo de nodulação, mas não as demais características agronômicas avaliadas.

3) A adição de potássio não afetou a produção dos cultivares em nenhum dos locais estudados. Houve apenas efeito diferencial na absorção do elemento para o crescimento, sendo o cultivar IAC-14 mais exigente.

4) Em condições de inverno, nos locais estudados, deve-se adicionar nitrogênio para maximizar a produção. 
5) Os cultivares estudados comportaram-se distintamente nos tres locais quanto aos parametros estudados. 0 cultivar IAC-14 mostrou ser melhor adaptado às condições de Mococa e, o IAC-8 em Votuporanga. Em Ribeirão Preto ambos os cultivares se comportaram de modo similar. 


\section{REFERÊNCIAS BIBILOGRÄFICAS}

ADAMS, C. A. \& SHEARD, R. W. Alterations in the nitrogen metabolism of Medicago sativa and Dactyiis glomerata as influenced by potassium and sulfur nutrition. Canadian Journal of Plant science, ottawa, 46:671-680, 1966.

ALCÁNTAR GONZÁLES, G. \& TIRADO TORRES, J. L. Las dos vias de asimilación del nitrógeno en soya y otras leguminosas. Terra, Chapingo, 9: 59-68, 1991.

ALLOS, H. E. \& BARTHOLOMEW, W. Y. Replacement of symbiotic fixation by available nitrogen. Soil science, Baltimore, 87: $61-66,1959$.

ANDREW, C. S. BRYAN, W. W. Pasture studies on the coastal lowlands of sub-tropical Queensland: I - Introduction and initial plant nutrient studies. Australian Journal of Agricultural Research, Melbourne, 6: 265-290, 1955.

BARTA; A. L. Response of symbiotic $\mathrm{N}_{2}$ fixation and assimilate partitioning to $k$ supply in alfalfa. Crop Science, Madison, 22: 89-92, 1982. 
BATAGLIA, O. C.; MASCARENHAS, H. A. A. Nutriçăo mineral da soja In: A soja no Brasil Central. Campinas, Eundaçăo Cargill. 1982. 2a. ed. rev. ampl. pl15-133.

BATAGLIA, O. C.; TEIXEIRA, J. P. F. ;FURLANI, P. R.; FURLANI; A. M. C.; GALLO, J. R. Análise quimioa de plantas. Campinas, Instituto Agronômico, 1978. 31p (Circular, 87)

BEARD, B. H. \& HOOVER, R. M. Effect of nitrogen on nodulation and yield of irrigated soybeans. Agronomy Journal, Madison, 63: 815-816, 1971.

BHANGOO, M. S. \& ALBRITTON, D. J. Effect of fertilizer nitrogen, phosphorus, and potassium on yield and nutrient content of Lee soybeans. Agronomy Journal, Madison, 64: 743-746, 1972.

BOONKERD, N.; WEBER, D. F.; BEZDICEK, D. F. Influence of Rhizobium japonicum strains and inoculation methods on soybeans grown in Rhizobia-populated soil. Agronomy Journal, Madison, 70: 547-549, 1978.

BOSWELL, F. C. \& ANDERSON, O. E. Effect of time of molibdenum application on soybean yield and nitrogen, oil and molibdenum contents. Agronomy Journal, Madison, 61: $58-60,1969$. 
BOUNIOLS, A.; CABELGUENNE, M.; JONES, C. A.; CHALAMET, A.; CHARPENTEAU, J. L.; MARTY, J. R. Simulation of soybean nitrogen nutrition for a silty clay soil in southern France. Field Crops Research, Amsterdam, 26: 19-34, 1991.

BOUNIOLS, A.; CLEYENT-MAREL, J. C.; CROZAT, Y., DREVON, J. J.; HECKMAN,M.O.; ABATON, J.; SALSAC, L.; LAGACHERIE, B.; CONEJERO, G.; ROBIN, O.; WERY, J.; WARENBOURG, F. F. Nutrition azotée du soya: les 2 voies de l'assimilation de l'azotée. In: Le soja: physiologie de la plante et adaptatión aux conditions françaises. Ed. Cetion-INRA, 1986, p38-46.

BUIS, R.; BARTHOU, H.; ROUX, B. Effect of temporary chilling on foliar and caulinary growth and productivity in soybean (Glycine max). Annals of Botany, Londres, 61:705-715, 1988.

CALDWELL, B. E. \& VEST, G. Nodulation interaction between soybean genotypes and serogroups of Rhizobium japonicum. Crop Soience, Madison, 8: 680-682, 1968.

CARRIERI, A. P.; TSUNECHIRO, A.; BESSA JUNIOR, A. A.; ALMEIDA, A.; AGUIAR, A. R. C.; AMARO, A. A.; FERREIRA, C. R. R. P. T.; SILVA, C. R. L.; BASTOS FILHO, G. S.; OKAWA; H.; KIYUNA, I.; SILVA, J. R.; GONÇALVES, J. S.; 
MIRANDA, L. C.; ROCHA, M. B.; MARGARIDO, M. A.; OLIVEIRA, M. D. M.; MIRANDA, M. C.; MARTIN, N. B.; JUNQUEIRA, P. C.; OLIVEIRA, S. J. 'M.; NOGUEIRA JUNIOR, S.; EREITAS, S. M.; ARRUDA, S. T.; MARTINS, S. S.; OLIVEIRA, V. F. Prognóstico agrícola 1993/94: algodão, amendoim, arroz, feijão, mandioca, milho, soja. Informações Econômicas, São Paulo, 23: 86-95, 1993.

COSTA, J. A. \& MARCHEZAN, E. Caracteristicas dos estádios de desenvolvimento da soja. Campinas, Eundaçăo Cargill, 1982. 30p.

DE MOOY, C. J. \& PESEK, J. Nodulation responses of soybeans to added phosphorus, potassium and calcium salts. Agronomy Journal, Madison, 58: 275-280, 1966.

DUKE, S. H. \& COLLINS, M. Role of potassium in legume dinitrogen fixation. In: MUNSON,R.D. (ed.) Rotassium in agrioulture. Madison, American Society of Agronomy, 1985. p443-465.

DUKE, S. H.; COLLINS, M.; SOBERALSKE, R. M. Effects of potassium fertilization on nitrogen fixation and nodules enzymes of nitrogen netabolism in alfalfa. Crop Science, Madison, 20: 213-219, 1980. 
EAGLESHAM， A. R. J.; AYANABA, A.; RANGA RAO, V.; ESKEW, D.

L. Mineral $\mathbb{N}$ effects on cowpea and soybean crops in a Nigerian soil. I. Development, nodulation, acetylene reduction and grain yield. Plant and soil, Haia, 68: $171-178,1982$.

FRANCO, A. A.\& DOBEREINER, J. Especificidade hospedeira na simbiose com Rhizobium-feijão e influência de diferentes nutrientes. Pesquisa agropeouária brasileira, Brasilia, 2: 467-474, 1967.

FRANCO, A. A.; EONSECA, O. O. M.; MARRIEL, I. E. Efeito do nitrogênio mineral na atividade da nitrogenase e da nitrato-redutase durante o ciclo da soja no campo. Revista Brasileira de Ciência do solo, Campinas, 2: $110-114,1978$.

GIBSON, A. H. \& HARPER, J. E. Nitrate effect on nodulation of soybean by Bradyrhizobium japonicum. Crop Science, Madison, 25:497-501, 1985.

HAM, G. E.; LIENER, I. E.; EVANS, S. D.; FRAZIER, R. D.; NELSON, W. W. Yield and composition of soybean seed as affected by $\mathrm{N}$ and $\mathrm{S}$ fertilization. Agronomy Journal, Madison, 67: 293-297, 1975. 
HAMMOND, L. C. Rate nutrient uptake by soybeans on two Iowa soils. Ames, 1949. 104p. (M.S. Thesis, Iowa State University).

HANWAY,J.J. \& THOMPSON,H.E. HON a soybean plant develops? Ames. Iowa State University of Science and Technology. Cooperative Extension Service. Ames. 1971. 17p (Special Report, 53 rev).

HANWAY, J. J. \& WEBER, C. R. Accumulation of $N, P$, and $K$ by soybean (Glycine $\max$ (L.) Merril) plants. Agronomy Journal, Madison, 63: 406-408, 1971a.

HANWAY, J. J. \& WEBER, C. R. DrY matter accumulation in soybean (Glycine max (L.) Merril) plants as influenced by $N$, $P$, and $K$ fertilization. Agronomy Journal, Madison, 63: 263-266, 1971b.

HANWAY, J. J. \& WEBER, C. R. N,P, and $K$ percentages in soybean (Glycine max (L.) Merril) plant parts. Agronomy Journal, Madison, 63: 286-290, 1971c.

HARDY, R. W. F.; BURNS, R. C.; HOLSTEN, R. D. Applications of the acetylene-ethylene assay for measurement of nitrogen fixation. Soil Biology and Biochemistry, Oxford, 5: 47-81, 1973. 
HARPER, J. E. Contribution of dinitrogen and soil fertilizer nitrogen to soybean (Glycine max (L.) Merr.) production. In: HILL, L.D. (ed.) Woŕld soybean Research. 1976. Proceedings of the World Soybean Conference. Danville. Interstate Printers \& Publishers Inc., plo1107

HATCH, D. J. \& MACDUFF, J. H. Concurrent rates of $\mathrm{N}_{2}$ fixation, nitrate and ammonium uptake by white clover in response to growth at different root temperatures. Annals of Botany, Londres, 67: 265-274, 1991.

HERRIDGE, D. F. \& BERGENSEN, E. J. Symbiotic nitrogen fixation In: WILSON,J.R. (ed.) Advances in nitrogen oyoling in agrioultural ecosystems. Symposium on Advances in Nitrogen Cycling in Agricultural Ecosystems. 1987. CAB, Brisbane. 1988. p46-65.

HINSON, K. Nodulation responses from nitrogen applied to soybean half-root systems. Agronomy Journal, Madison, 67: $799-804,1975$.

JIMENEZ J., A. M.; OLALDE-PORTUGAL, V. ; PENA-CABRIALES Evaluatión en campo de Bradyrhizobium japonicum en dos variedades de soya (Glycine max L.). Terra, Chapingo, 9: $79-86,1991$. 
JOHNSON, H. W. \& MEANS, U. M. Interactions between genotypes of soybean and genotypes of nodulating bacteria. Agronomy Journal, Madison, 52: 651-654, 1960.

JONES, G. D.,; LUTZ, J. A.; SMITH, T. J. Effects of phosphorus and potassium on soybean nodules and seed yield. Agronomy Journal, Madison, 69:1003-1006, 1977.

KANAYAMA, Y. \& YAMAMOTO, Y. Inhibition fo nitrogen in soybean plants supplied with nitrate. II. Accumulation and properties of nitrosylleghemoglobin in nodules. Plant Cell Physiology, Kyoto, 31: 207-214, 1990

KURTZ, L. T. Fertilizer needs of the soybean. In: HILL,L.D. (ed.) World Soybean Research: Proceedings of the World Soybean Research Conference. Danville;, Interstate Printers \& Publishers 1976. p85-100.

LATHWELL, D. J. \& EVANS, E. E. Nitrogen uptake from solution by soybeans at successive stages of grown. Agronomy Journal, Madison, 43: 264-270, 1951.

MALAVOLTA, E. \& CRÓCOMO, O. J. O potássio e a planta. In: Simpósio sobre potássio na agricultura brasileira. Piracicaba. Anais. Fundação IAPAR, Londrina, 1982. p95112. 
MARKUS, O. K. \& BATTLE, W. R. Soil and plant responses to long-term fertilization of alfalfa (Medicago sativa L.). Agronomy Journal, Madison, 57:613-616, 1965.

MASCARENHAS, H. A. A.;BRAGA, N. R.; MIRANDA, M. A. C.; TISSELLI EILHO, O.; MIYASAKA, S. Calagem e adubação da soja. In: A soja no Brasil Central. Fundação Cargill. 2a. ed. rev. ampl. Campinas, 1982 p 137-211.

MASCARENHAS, H. A. A.; BRAGA, N. R.; TISSELI FILHO, O.; MIRANDA, M. A. C.; ROSTON, A. J. Calagem e adubą̣ão para a soja. Campinas, Instituto Agronômico, 1976. 7p. (Circular, 51).

MASCARENHAS, H. A. A.; DEMATTE, J. D.; MIYASAKA, S.; IGUE, T. Estudos preliminares sobre a adubaçâoo econômica da soja (Glycine max (L.) Merril), na regiăo da Aita Mogiana, em latosol roxo e latosol vermelho-escuro, fase arenosa. Instituto Agronômico, Projeto BNDE/ANDA/CIA (3) $19717 p$.

MASCARENHAS, H. A. A.; HIROCE, R.; BRAGA, N. R.; MIRANDA, M. A. C.; BULISANI, E. A.; POMMER, C. V.; SAWAZAKI, E.; GALLO, P. B.; PEREIRA, J. C. V. N. A. Efeito do N residual de soja na produção do milho. 2 ed. rev. atual. Campinas, Instituto Agronômico, 1983. $24 \mathrm{p}$ (Boletim técnico, 58). 
MASCARENHAS, H. A. A.; NEPTUNE, A. M. L.; MURAOKA, T.; BULISANI, E. A.; HIROCE, R. Absorção de nutrientes por cultivares de soja (Glycine max (L.) Merril) Revista Brasileira de Ciência do solo, Campinas, 4: 92-96, 1980 .

MIRANDA, M. A. C.; BULISANI, E. A.; MASCARENHAS, H. A. A.; PEREIRA, J. C. V. N. A.; GALLO, P. B.; LELIS, L. G. L.; TAVARES, D. Q.; COSTA, A. S. Cultivar de soja IAC-14. Campinas. Instituto Agronômico, 1988. 4p. (Folder).

MIRANDA, M. A. C.; MASCARENHAS, H. A. A.; BRAGA, N. R.; KIIHL, R. A. S. Cultivar de soja "IAC-8" Campinas, Instituto Agronômico, 1980. 8p. (Circular, 113).

MIYASAKA, S.; GUIMARÄES, G.; KIIHL, R.. LOVADİNI, L. A. C.; DEMATTE, J. D. Variedades de soja indiferentes ao fotoperiodismo e tolerantes a baixas temperaturas. Bragantia, Campinas, 29:169-173, 1970.

MUZILLI, o. Nutrição e adubação potássica da soja no Brasil. In: YAMADA, T. et al. Piracicaba, Instituto da Potassa \& Eosfato/Instituto Internacional da Potassa. 1982. p. 339-372. 
NANGJU, D. Soybean response to indigenous rhizobia as influenced by cultivar origin. Agronomy Journal, Madison, 72: 403-406, 1980.

NOGUEIRA, M. C. S. Curso de estatistica experimental aplicada a experimentação agronômica. Piracicaba. ESALQ. 1991. 168p.

OHLROGGE, A. J. Mineral nutrition of soybeans. Advances in Agronomy, Ann Arbor, 122: 229-263, 1960.

OLIVEIRA, J. B. \& PRADO, H. Levantamento pedológico semidetalhado do Estado de são Paulo: quadricula de Ribeirăo Preto SE-233-V-C-I. Campinas. Instituto Agronômico, 1983. Escala 1:100.000 (Convênio EmbrapaSAA) .

OUATTARA, S. WEAVER, D. B. Effect of growth on yield and agronomic characteristics of late-planted soybean. Crop Science, Madison, 34: 870-873, 1994.

PATTERSON, T. G. \& LARUE, T. A. Nitrogen fixation by soybeans: seasonal and cultivar effects and comparisons of estimates. Crop Science, Madison, 23: 488-492, 1983. 
PERKINS, A. T. The effect of several mineral fertilizers upon nodulation of Virginia soybeans. Soil soience, Baltimore, 17: 439-447, 1924 .

EUECH, J. BOUNIOLS, A. Besoins en eau en azote du soya: importance des phases sensibles. In: Le soya: physiologie de la plante et adaptatión aux conditions françaises. CETION-INRA. 1986. p33-37.

RAPER JR, C. D. \& BARBER, S. A. Rooting system of soybeans. II. Physiological effectiveness as nutrient absorption surfaces. Agronomy Journal, Madison, 62: 585-588, 1970.

REESE JR, P. F. \& BUSS, G. R. Response of dryland soybeans to nitrogen in full-season and doublecrop systems. Journal of Production Agriculture, Madison, 5:528-531, 1992.

RITCHEY, K. D.; SOUSA, D. M. G.; LOBATO, E. Potássio em solo de cerrado.I. Resposta à adubação potássica. Revista Brasileira de Ciècia do Solo, Campinas, 3: 29$32,1979$.

SINCLAIR, T. R. \& DE WIT, C. T. Photosynthate and nitrogen requiremens for seed production by various crops. soience, washington, 189: 565-567, 1975. 
SINCLAIR, T. R.; SOFFES, A. R.; HINSON, K.; ALBRECHT, S. L.; PFAHLER, P. L. Genotypic variation in soybean nodule number and weight. Crop science, Madison, 31: 301-304, 1991 .

SUTTON, C. D. Cual es la mejor fuente de nitrógeno? Agricultura de las Americas, Overland Park, 42: 6-11, 1993.

STAMFORD, N. P.; NEPTUNE, A. M. L.; SILVA, E. P. Efeito do potássio em presença de N-mineral, na nodulação, crescimento e absorção de nutrientes por Vigna unguiculata (L.) Walp. Revista Brasileira de Ciència do Solo, Campinas, 4: 99-103, 1980.

TANAKA, A. The physilogy of soybean yiels improvement. In: SHANMUGASUNDARAM, S. \& SULZBERGER, E.W. (ed.) Soybean in Tropical and subtropical cropping systems. The Asian Vegetable Research and Development Center, Shanhua, Taiwan, China. 1985. p323-331.

TANAKA, R. T. \& MASCARENHAS, H. A. A.'soja: nutrição, correção do solo e adubação. Campinas, Fundação Cargill, 1992. 60p. 
TANNER, J. W. A ANDERSON, I. C. External effect to combined nitrogen on nodulation. Plant Physilogy, Lancaster, $39: 1039-1043,1964$.

THOMAS, J. F. \& RAPER JR, C. D. Photoperiodic control of seed filling for soybeans. Crop science, Madison, 16: $667-672,1976$.

THOMAS, R. J. \& HUNGRIA, M. Effect of $K$ on $\mathrm{N}_{2}$ fixation transport and $\mathrm{n}$ harvest index of beans (Fhaseolus vulgaris). Journal of Plant Nutrition, New York, 11: $175-188,1988$.

TSAI, S. M.; BONETTI, R.; AGBALA, S. M.; ROSSETTO, R. Minimizing the effect of mineral nitrogen on biological nitrogen fixation in common bean by increasing nutrient levels. Plant and Soil, Haia, 152: 131-138, 1993.

UZIAK, Z. Investigations on nitrogen of soybean (Glycine hispida) and tomato (Solanum Iycopersicum). Annales Universitatis Mariae Curie-sklodowska, Lublin, 15E: $145-176,1960$.

UZIAKOWA, $z$. The influence of different forms nitrogen nutrition upon the growth and symbiosis of soybeans. Acta Miorobiologica Polonica, Warszawa, 8: 315-318, 1959. 
VASILAS, B. L. \& FUHRMANN, J. J. Field response of soybean to increased dinitrogen fixation. Crop soience, Madison, 33: 785-787, 1993.

vernetTI, F. J. Soja. Campinas. Fundaçåo Cargill, 2v. 1983. 990p.

VERNETTI, F. J. Inoculação da soja. Ministério da Agricultura. Departamento Nacional de Pesquisa Agropecuária do Sul. 1971. Pelotas. 31p. (Boletim técnico, 75).

VEST, G. D.; WEBER, F.; SLOGER, C. Nodulation and nitrogen fixation. In: CALDWELL, B. E.; JOHNSON, H. W. (ed.) Soybeans: Improvement, production and uses. Madison, American Society of Agronomy, 1973. p353-390.

WATERER, J. G.; VESSEY, J. K.; RAPER JR, C. D. Stimulation of nodulation in field peas (Pisum sativum) by low concentrations of ammonium in hydroponic culture. Physiologia Plantarum, Copenhagen, 86: 215-220, 1992.

WEBER, C. R. Nodulating and nonnodulating soybean isolines: II. Response to applied nitrogen and modified soil Conditions. Agronomy Journal, Madison, 58: 46-49, 1966. 
YAMADA, T. O potássio na cultura da soja. Associação Brasileira para pesquisa da Potassa e do Fosfato, Piracicaba, 1993. 4p (Informações Ágronômicas, 64) 